\title{
Ozone/Peroxide Advanced Oxidation in Combination with Biofiltration for Taste and Odour Control and Organics Removal
}

by

Divyam Beniwal

A thesis submitted in conformity with the requirements

for the degree of Master of Applied Science

Civil Engineering

University of Toronto

(C) Copyright by Divyam Beniwal 2017 


\section{OZONE/PEROXIDE ADVANCED OXIDATION IN COMBINATION WITH BIOFILTRATION FOR TASTE AND ODOUR CONTROL AND ORGANICS REMOVAL}

Divyam Beniwal

Master of Applied Science, 2017

Graduate Department of Civil Engineering

University of Toronto

\section{ABSTRACT}

Ozone $\left(\mathrm{O}_{3}\right)$ prior to biofiltration can be an effective treatment strategy to achieve multiple drinking water quality goals. These goals include primary disinfection, improved removal of biodegradable organic carbon (generated as a result of ozonation), and oxidation of geosmin and MIB. However, $\mathrm{O}_{3}$ efficiency is dependent on source water characteristics, which impacts performance. This pilot study investigated the effectiveness of advanced oxidation incorporating $\mathrm{O}_{3}$ and hydrogen peroxide/ozone $\left(\mathrm{H}_{2} \mathrm{O}_{2} / \mathrm{O}_{3}\right)$ with biofiltration (containing biologically active carbon (BAC) and anthracite) for geosmin and MIB control and disinfection by-product (DBP) precursor reduction.

Application of $0.2 \mathrm{H}_{2} \mathrm{O}_{2} / \mathrm{O}_{3}(\mathrm{mg} / \mathrm{mg})$ prior to $\mathrm{BAC}$ resulted in optimal MIB and geosmin removal, especially in cold-water conditions $\left(\mathrm{T}=10^{\circ} \mathrm{C}\right)$. In warmer temperatures $\left(22^{\circ} \mathrm{C}\right), \mathrm{BAC}$ alone was a suitable treatment technology for both geosmin and MIB. In terms of DBP precursor reduction, $0.1 \mathrm{H}_{2} \mathrm{O}_{2} / \mathrm{O}_{3}(\mathrm{mg} / \mathrm{mg})$ in combination with $\mathrm{BAC}$ was found to be the most effective treatment strategy with 37\% THM and 10\% HAA precursor reductions. 


\section{ACKNOWLEDGEMENTS}

This work was funded by the Natural Sciences and Engineering Research Council of Canada (NSERC) Chair in Drinking Water Research (DWRG) at the University of Toronto, and the Ontario Research Fund (ORF).

I am deeply grateful to my supervisor Dr. R.C. Andrews for his support and continued guidance throughout the project academically and professionally. I also thank Dr. Susan Andrews for reviewing my thesis and providing invaluable comments and feedback.

I thank Liz Taylor-Edmonds for patiently editing my countless paper drafts, John Armour for training and assisting me with the pilot work, and Gwen C. Woods for training me on GC-MS. I am indebted to Kevan Light, René Gagnon and everyone else at Peterborough Utilities Commission for providing a stimulating and fun environment to work. I thank Nicolas Peleato and Mike McKie for their help, guidance, and general encouragement along the way. I would like to express my gratitude to Jim Wang for training me in the lab and Jacque-Ann Grant, Yanjun Jiang, Chris Jiang, Tyler Yang, and Chengjin Wang for their assistance in the lab and to my DWRG colleagues for their encouragement.

Thanks to all my friends here at the University of Toronto - Dikshant, Appana, Vivek, Balsher, Kirti, and Pawan for their continuous support. Finally, I am grateful and thankful to my parents and my brother for unwavering support, encouragement, and belief in me throughout this journey. 


\section{TABLE OF CONTENTS}

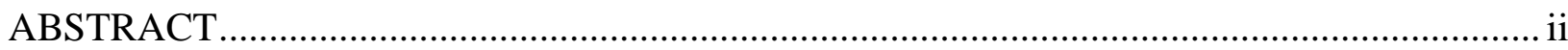

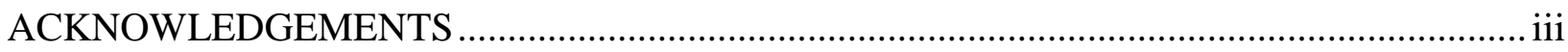

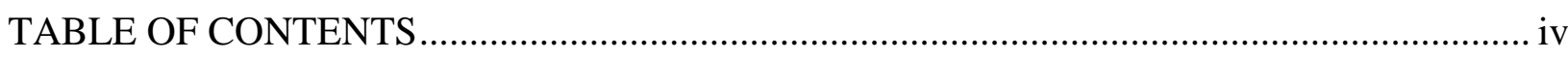

LIST OF TABLES …………………………………....................................................... vi

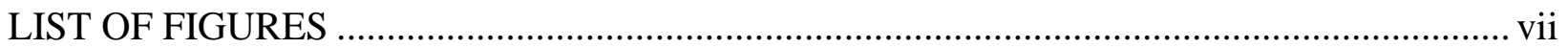

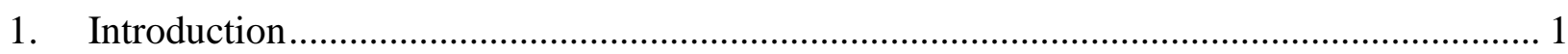

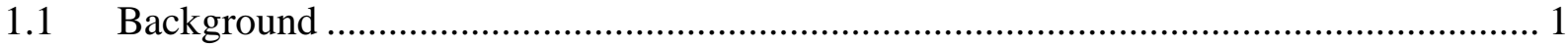

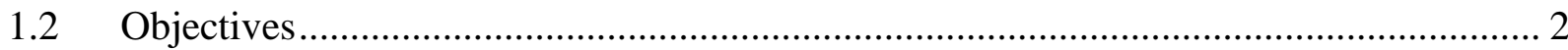

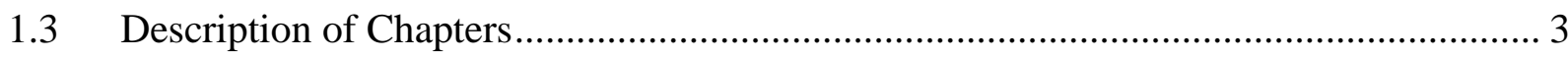

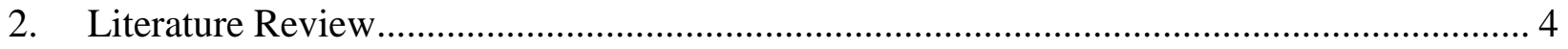

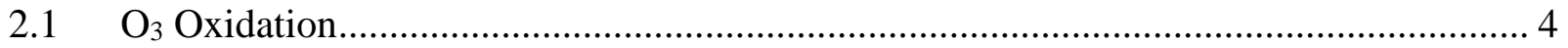

2.1.1 $\mathrm{O}_{3}$ and $\mathrm{H}_{2} \mathrm{O}_{2} / \mathrm{O}_{3}$ Advanced Oxidation in Water Treatment..................................... 4

$2.2 \mathrm{O}_{3}$ and $\mathrm{H}_{2} \mathrm{O}_{2} / \mathrm{O}_{3}$ Prior to Biofiltration for Organics Removal ........................................ 7

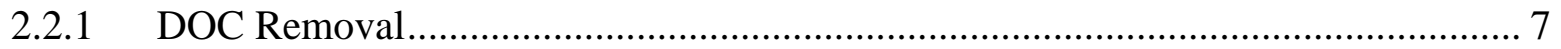

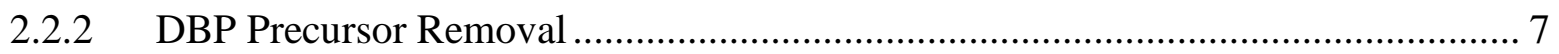

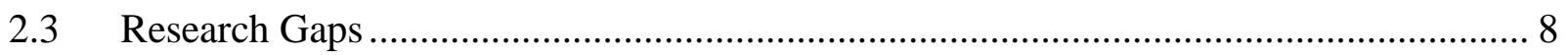

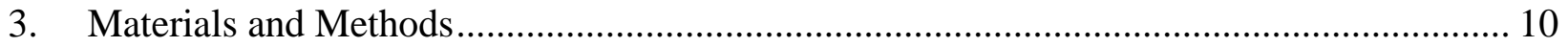

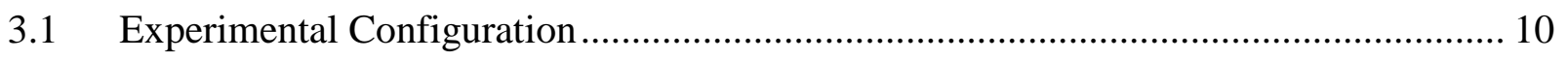

3.1.1 Pilot Plant Configuration .............................................................................. 10

3.1.2 Biofiltration Pilot ........................................................................................... 10

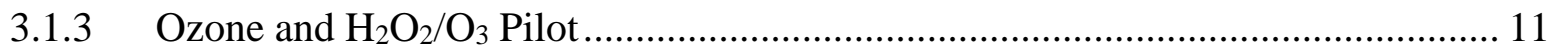

3.1.4 Experimental Design.................................................................................. 11

3.1.5 Spike and Sampling Procedure .......................................................................... 13

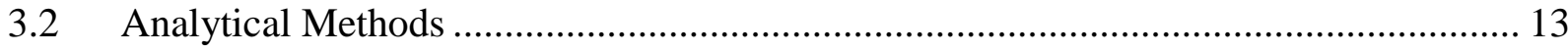

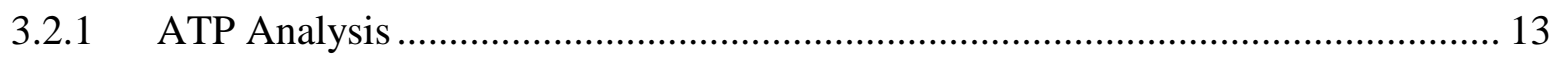

3.2.2 Dissolved Organic Carbon ............................................................................ 13

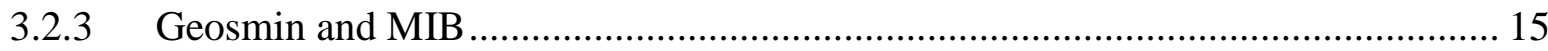

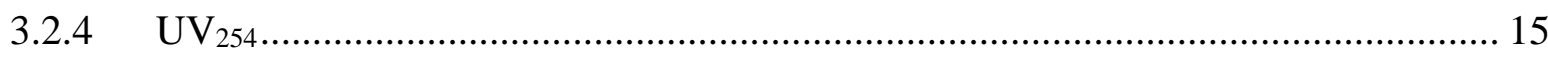

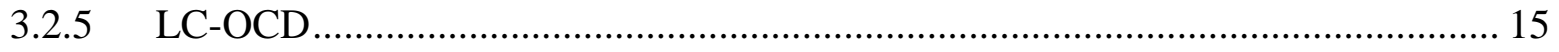


3.2.6 Disinfection By-Product Formation Test............................................................. 16

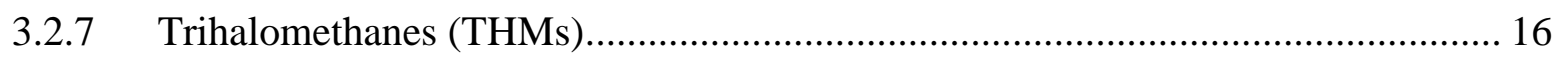

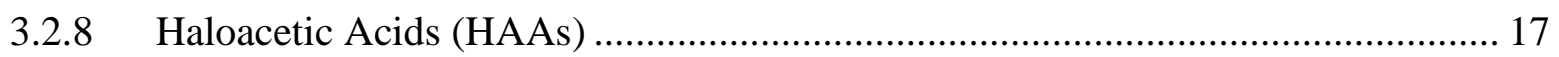

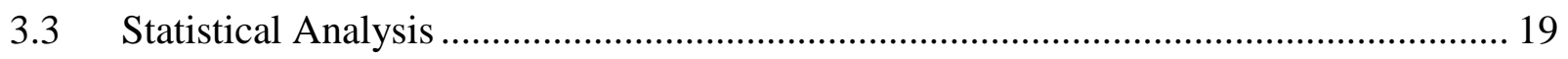

4. Ozone/Peroxide Advanced Oxidation in Combination with Biofiltration............................ 20

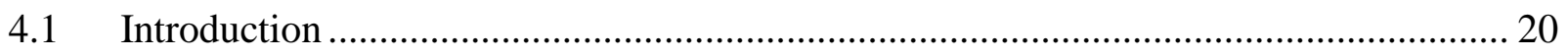

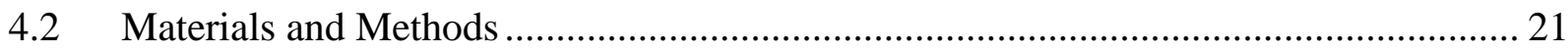

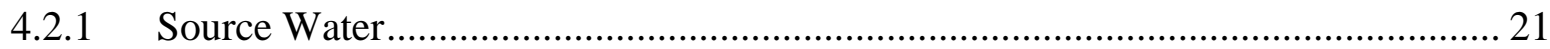

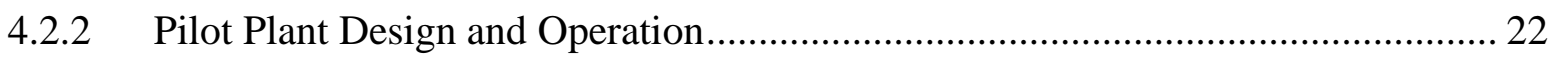

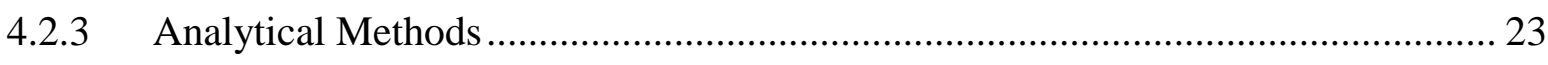

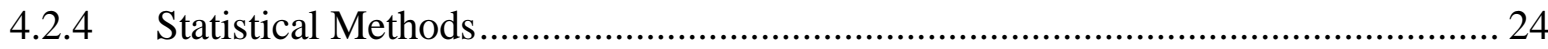

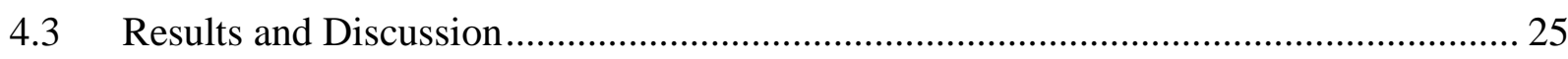

4.3.1 Geosmin and MIB Removal by Conventional and Biological Filtration ............... 25

4.3.2 Impact of Pre-Oxidation and Temperature on Geosmin and MIB Removal .......... 26

4.3.3 Impact of Pre-Oxidation and Temperature on MIB and Geosmin ........................ 29

4.3.4 Impact of Pre-Oxidation Organics Removal........................................................ 33

4.3.5 Pre-Oxidation and Biofiltration for DBP Formation Reduction............................. 36

4.3.6 Filter Media ATP Analysis ................................................................................ 39

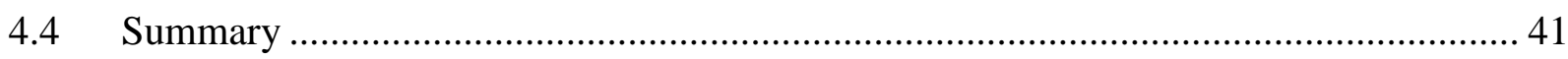

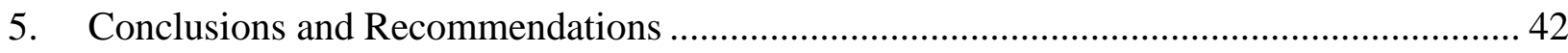

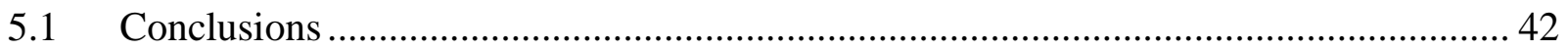

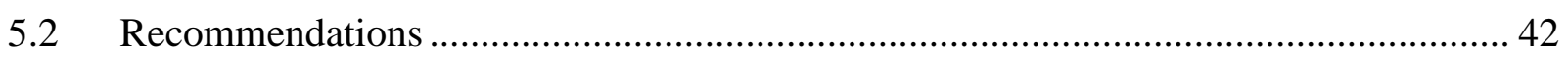

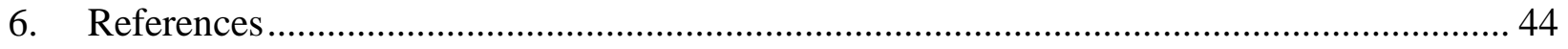

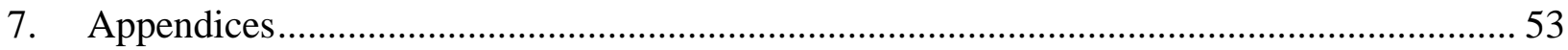

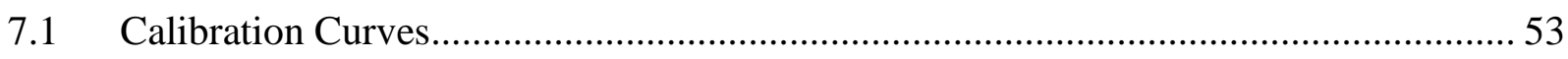

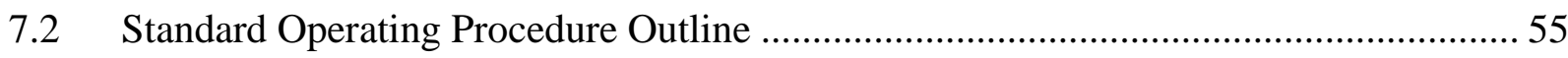

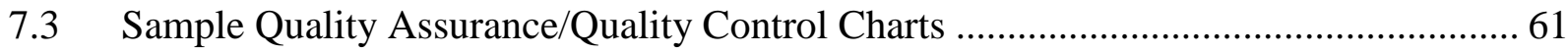

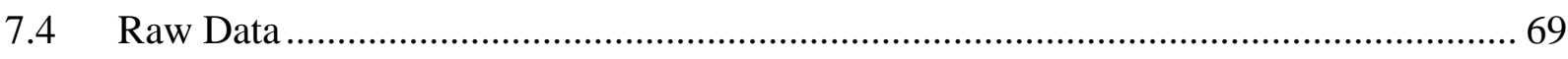




\section{LIST OF TABLES}

Table 2-1: Typical Initiators, Promoters, Scavengers for $\mathrm{O}_{3}$ Decomposition ............................. 5

Table 2-2: Summary of $\mathrm{O}_{3}$ Studies Characterizing the Impact of Water Matrix......................... 6

Table 2-3: Impact of $\mathrm{O}_{3}$ and $\mathrm{H}_{2} \mathrm{O}_{2} / \mathrm{O}_{3}$ Oxidation on Biofiltration ....................................... 8

Table 3-1: Summary of Raw and Pilot Plant Influent Water Quality...................................... 10

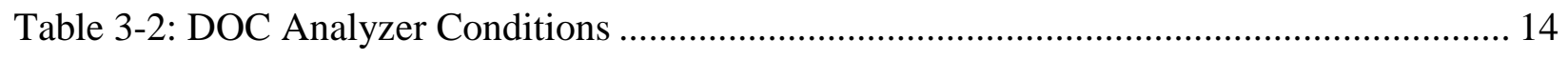

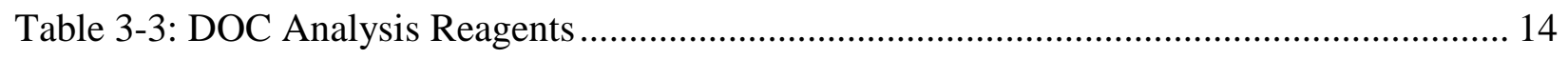

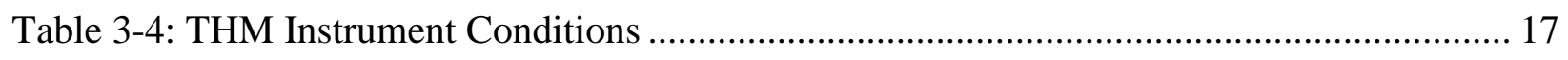

Table 3-5: THM Reagent Compounds ............................................................................... 17

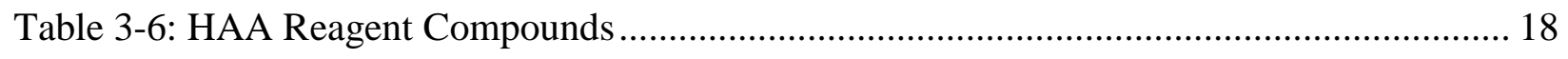

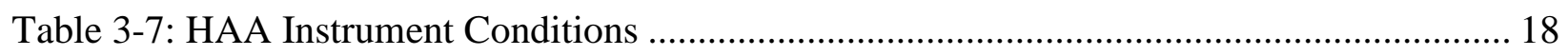

Table 4-1: Pilot Influent Water Quality ............................................................................... 22

Table 4-2: Pilot Plant Configuration to Illustrate Conditions ................................................. 23

Table 4-3: Geosmin and MIB Removals (\%) Across Conventional.......................................... 26

Table 4-4: Statistical $(\mathrm{p}<0.05)$ Comparison between Treatment Processes .............................. 27

Table 4-5: Statistical Comparison of Treatment Processes Using Paired T-Tests ..................... 30

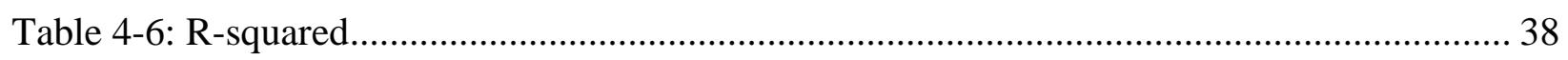

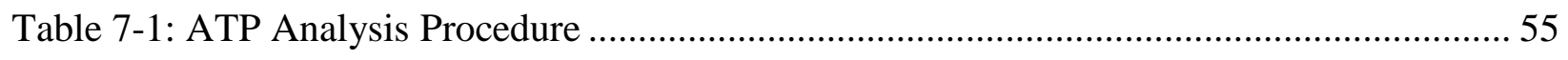

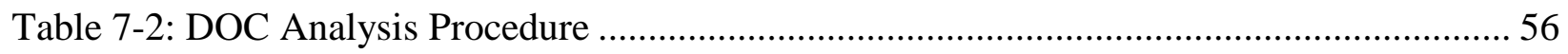

Table 7-3: Geosmin and MIB Extraction and Analysis Procedure ........................................... 56

Table 7-4: THM Extraction and Analysis Procedure ............................................................. 57

Table 7-5: HAA Extraction and Analysis Procedure ...............................................................5 59

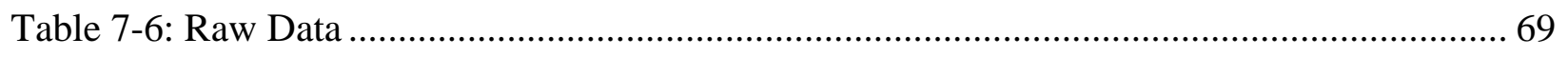




\section{LIST OF FIGURES}

Figure 3-1: Pilot Plant Schematic for Experimental Condition 1, 2, 3, and 4 ............................. 12

Figure 4-1: Geosmin, MIB, DOC, UV 254, THMFP, and HAAFP Removals ............................... 28

Figure 4-2: MIB Removals as a result of No Pre-Oxidation, Ozonation, $\mathrm{H}_{2} \mathrm{O}_{2} / \mathrm{O}_{3} \ldots \ldots \ldots \ldots \ldots \ldots \ldots . . . . . . . .31$

Figure 4-3: Geosmin Removals as a Result of No Pre-Oxidation, Ozonation, $\mathrm{H}_{2} \mathrm{O}_{2} / \mathrm{O}_{3} \ldots \ldots \ldots \ldots . . . . .32$

Figure 4-4: Reduction (\%) of DOC, $\mathrm{UV}_{254}$ absorbance, THMFP, HAAFP .................................. 34

Figure 4-5: \% Reduction of LC-OCD fractions from settled water.............................................. 35

Figure 4-6: \% Reduction of LC-OCD fractions across biofiltration ........................................... 39

Figure 4-7: ATP concentrations on the surface of BAF, BAC, and BAC control......................... 40

Figure 7-1: Sample DOC Calibration Curve (May 2016) ………………………………............ 53

Figure 7-2: Sample Geosmin and MIB Calibration Curve (August 2016) ................................... 53

Figure 7-3: Sample THM Calibration Curve (June 2016) …………………………………....... 54

Figure 7-4: Sample HAA Calibration Curve (June 2016) ............................................................ 54

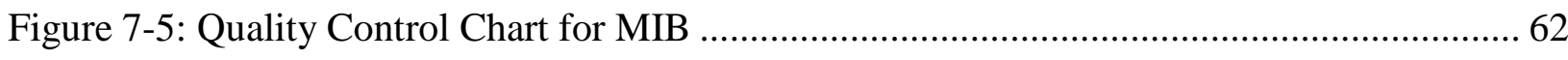

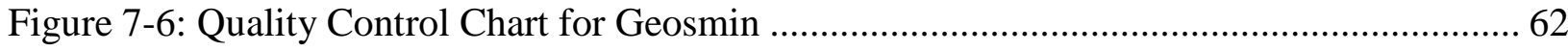

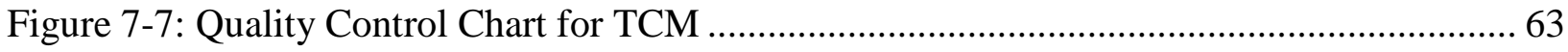

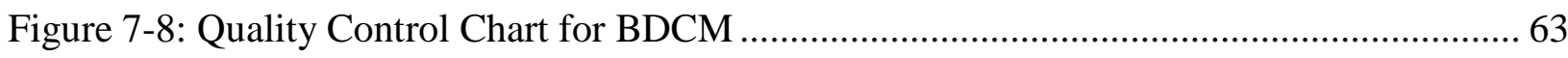

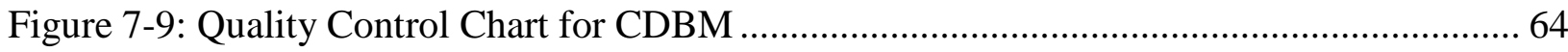

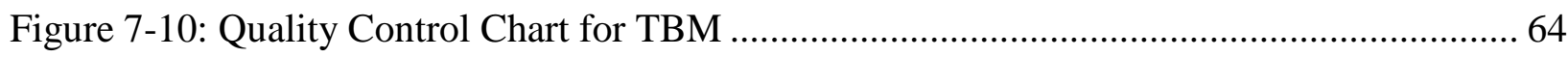

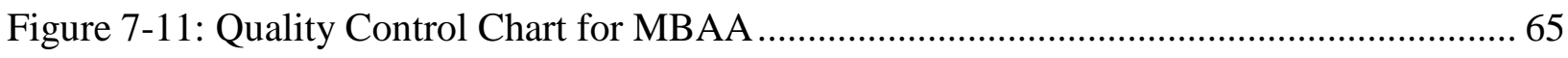

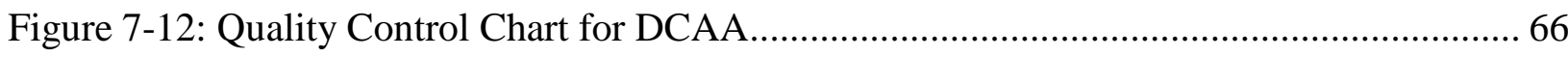

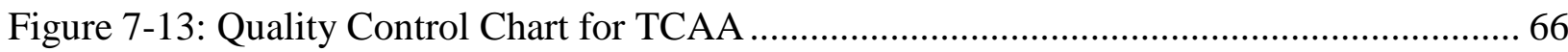

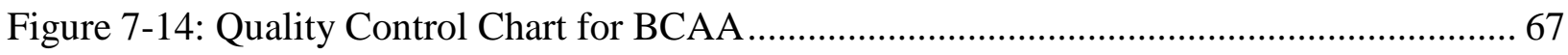

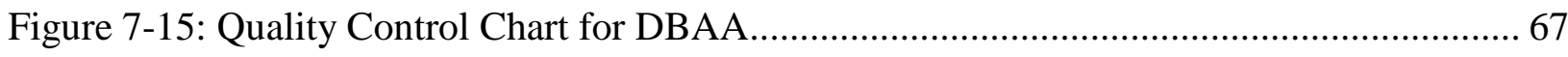

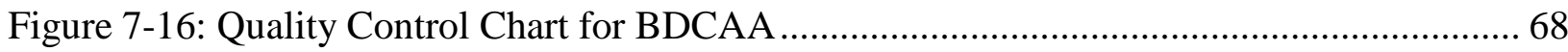

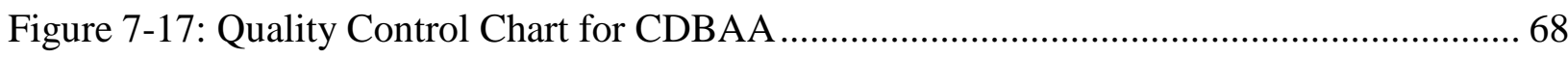




\section{NOMENCLATURE}

\begin{tabular}{|c|c|}
\hline$\%$ & Percent \\
\hline \pm & Plus/minus \\
\hline${ }^{\circ} \mathrm{C}$ & Degree(s) Celsius \\
\hline$<$ & Less than \\
\hline$>$ & More than \\
\hline$\alpha$ & Confidence level \\
\hline$\sim$ & Approximate \\
\hline $\mathrm{AOP}(\mathrm{s})$ & Advanced Oxidation Process(es) \\
\hline ATP & Adenosine tri-phosphate \\
\hline BAC & Biologically active carbon \\
\hline BAF & Biologically active anthracite \\
\hline BCAA & Bromochloroacetic acid \\
\hline BDCM & Bromodichloromethane \\
\hline BDCAA & Bromodichloroacetic acid \\
\hline $\mathrm{BDL}$ & Below Detection Limit \\
\hline BDOC & Biodegradable organic carbon \\
\hline $\mathrm{BDOC}_{\mathrm{r}}$ & Rapid biodegradable organic carbon \\
\hline $\mathrm{C}$ & Concentration \\
\hline $\mathrm{CAF}$ & Conventional anthracite filter \\
\hline $\mathrm{Cl}$ & Chlorine \\
\hline $\mathrm{cm}$ & Centimeter(s) \\
\hline $\mathrm{CO}_{3}^{2-}$ & Carbonate \\
\hline
\end{tabular}




\begin{tabular}{|c|c|}
\hline Conventional treatment & Coagulation, flocculation, settling, non-biological filtration \\
\hline CTS & Calcium thiosulphate \\
\hline $\mathrm{d}$ & diameter \\
\hline DBAA & Dibromoacetic acid \\
\hline DBCAA & Dibromochloroacetic acid \\
\hline DBCM & Dibromochloromethane \\
\hline DBP & Disinfection by-product \\
\hline DBP FP & Disinfection by-product formation potential \\
\hline DCAA & Dichloroacetic acid \\
\hline DOC & Dissolved organic carbon \\
\hline $\mathrm{EBCT}$ & Empty bed contact time \\
\hline $\mathrm{Fe}^{2+}$ & Ferrous \\
\hline FP & Formation potential \\
\hline FSP & Full-scale plant \\
\hline $\mathrm{g}$ & $\operatorname{Gram}(\mathrm{s})$ \\
\hline GAC & Granular activated carbon \\
\hline GC & Gas chromatography \\
\hline GC-MS & Gas chromatography - mass spectrometry \\
\hline GC-ECD & Gas chromatography-electron capture detection \\
\hline $\mathrm{H}_{2} \mathrm{O}_{2}$ & Hydrogen peroxide \\
\hline $\mathrm{H}_{2} \mathrm{O}_{2} / \mathrm{O}_{3}$ & Hydrogen peroxide/ozone \\
\hline $\mathrm{HO}_{2}^{-}$ & Hydroperoxide anion \\
\hline $\mathrm{HCO}_{3}^{-}$ & Bicarbonate \\
\hline
\end{tabular}




\begin{tabular}{|c|c|}
\hline HAA(s) & Haloacetic acids \\
\hline $\mathrm{L}$ & Litre(s) \\
\hline LC-OCD & Liquid chromatography-organic carbon detection \\
\hline LMW & Low molecular weight \\
\hline $\mathrm{m}$ & Meter(s) \\
\hline $\mathrm{m}^{-1}$ & $1 /$ meter(s) \\
\hline $\mathrm{m}^{2}$ & Squared meter(s) \\
\hline M & Molar concentration \\
\hline$M^{-1}$ & $1 /$ molar concentration \\
\hline MCAA & Monochloroacetic acid \\
\hline MBAA & Monobromoacetic acid \\
\hline MDL & Method detection limit \\
\hline $\mathrm{mg} / \mathrm{L}$ & Milligram(s) per liter \\
\hline $\mathrm{mg} / \mathrm{mg}$ & Milligram per milligram \\
\hline $\min$ & Minute(s) \\
\hline$\mu \mathrm{g} / \mathrm{g}$ & Microgram per grams \\
\hline MTBE & Methyl-tert -butyl-ether \\
\hline MW & Molecular weight \\
\hline NA & Not available \\
\hline N/A & Not applicable \\
\hline $\mathrm{NaOH}$ & Sodium hydroxide \\
\hline $\mathrm{Na}_{2} \mathrm{SO}_{4}$ & Sodium sulphate \\
\hline $\mathrm{ng} / \mathrm{g}$ & Nanogram(s) per gram \\
\hline
\end{tabular}




\begin{tabular}{|c|c|}
\hline $\mathrm{nm}$ & Nanometer(s) \\
\hline NOM & Natural organic matter \\
\hline ND & Not detected \\
\hline NS & Not Sampled \\
\hline NSERC & Natural Sciences and Engineering Research Council \\
\hline NTU & Nephelometric Turbidity Unit \\
\hline $\mathrm{O}_{3}$ & Ozone \\
\hline$\cdot \mathrm{OH}$ & Hydroxyl radicals \\
\hline $\mathrm{OH}^{-}$ & Hydroxide \\
\hline ORF & Ontario Research Fund \\
\hline OTC & Odour threshold concentration \\
\hline p-value & Probability value \\
\hline $\mathrm{PO}_{4}{ }^{3-}$ & Phosphate \\
\hline PWTP & Peterborough Water Treatment Plant \\
\hline PWTPP & Peterborough Water Treatment Pilot Plant \\
\hline $\mathrm{pH}$ & -log (hydrogen ions concentration) \\
\hline QA/QC & Quality assurance/quality control \\
\hline $\mathrm{R}^{2}$ & Coefficient of determination \\
\hline $\sec$ & Second(s) \\
\hline SPME & Solid phase micro-extrction \\
\hline SUVA & Specific ultraviolet absorbance (at $254 \mathrm{~nm}$ ) \\
\hline $\mathrm{T}$ & Temperature \\
\hline $\mathrm{t}$ & Student t-test value or student $t$ probability distributi \\
\hline
\end{tabular}




$\begin{array}{ll}\text { T\&O } & \text { Taste and odour } \\ \text { TBM } & \text { Tribromomethane } \\ \text { TBAA } & \text { Tribromoacetic acid } \\ \text { TCAA } & \text { Trichloroacetic acid } \\ \text { TCM } & \text { Chloroform } \\ \text { THM(s) } & \text { Trihalomethane(s) } \\ \text { THMFP } & \text { Trihalomethane formation potential } \\ \text { TOC } & \text { Total organic carbon } \\ \text { UC } & \text { Uniformity coefficient } \\ \text { USEPA } & \text { United States Environmental Protection Agency } \\ \text { UV } & \text { UV absorbance at 254 nm } \\ \text { w/w } & \text { Weight per weight }\end{array}$




\section{Introduction}

\subsection{Background}

$\mathrm{O}_{3}$ have long been used in drinking water treatment for natural organic matter (NOM) oxidation, taste and odour ( $\mathrm{T} \& \mathrm{O})$ control, color removal, and disinfection in Europe and more recently in North America (Schulz et al., 2014). The amendment of Safe Drinking Water Act by United States Environmental Protection Agency (USEPA) in response to the emerging threats to drinking water safety after 1993 Milwaukee Cryptosporidium outbreak and 2000 Walkerton's E.coli tragedy encouraged the use of incorporation of $\mathrm{O}_{3}$ as a regulatory compliance (Rice et al., 1998; Hrudey et al., 2003). High initial capital costs combined with extensive operation and maintenance have deterred municipalities in implementing such an attractive solution for extended period of time (Plumlee et al., 2014). However, the benefit of applying an advanced treatment for a purpose of serving a better-quality drinking water (in terms of aesthetics, consumer satisfaction, and regulatory standards), containing lower disinfection by-products (DBPs) have attracted municipalities to implement $\mathrm{O}_{3}$ as a pre-treatment strategy before filtration.

Although the application of $\mathrm{O}_{3}$ can achieve multiple treatment benefits, its application in bromine containing waters can produce bromate, an ozonation by-product, which has been classified by USEPA as a probable human carcinogen (USEPA, 2006). pH reduction using chemical addition can reduce bromate formation (von Gunten and Oliveras, 1998). However, such treatment strategies can impact removals of other contaminants, such as T\&O compounds with ozonation (Srinivasan and Sorial, 2011). Therefore, site-specific pilot studies should be conducted when considering ozonation.

$\mathrm{O}_{3}$ has also been used for NOM removal. $\mathrm{O}_{3}$ breaks down NOM into smaller and more biodegradable organics, which leads to microbial regrowth in distribution systems (Urfer et al., 1997). This has been associated with $\mathrm{T} \& \mathrm{O}$ issues, accelerated corrosion of water mains, and increased chlorine demands. Biofiltration can be used following ozonation to overcome the biological instability and may provide another barrier against organics removal and DBP precursor reduction (Rittmann and McCarty, 2001). However, biofiltration performance using biologically active carbon (BAC) has shown to be impacted by water temperature (Emelko et al., 2006; Moll 
et al., 1999), empty bed contact time (EBCT), and accumulation of attached microbial biomass (Elhadi et al., 2006). Because of these factors, BAC performance in terms of geosmin, MIB, as well as DBP precursor removals can vary significantly (de Vera et al., 2016; Elhadi et al., 2004; Guo et al., 2016). In addition, $\mathrm{O}_{3}$ efficiency is dependent on source water characteristics such as pH, DOC, alkalinity, and temperature (Westerhoff et al., 2006), which warrants site-specific pilot studies for optimization of $\mathrm{O}_{3}$ and biofiltration treatment.

$\mathrm{O}_{3}$ efficiency can be improved with the addition of $\mathrm{H}_{2} \mathrm{O}_{2}$ to produce hydroxyl radicals $(\cdot \mathrm{OH})$ with fast reaction rates for geosmin and $\mathrm{MIB}\left(\mathrm{K}_{\mathrm{OH}} \sim 10^{9} \mathrm{M}^{-1} \mathrm{~s}^{-1}\right)$ (Lee and von Gunten, 2016). Previous pilot studies have reported increases of 10-15\% in geosmin and MIB removals upon $\mathrm{H}_{2} \mathrm{O}_{2}$ addition (Park et al., 2015; Wang et al., 2015). However, much of the existing information regarding $\mathrm{H}_{2} \mathrm{O}_{2} / \mathrm{O}_{3}$ optimization has been based on the bench-scale studies (Chang et al., 2002; Li et al., 2012; Mizuno et al., 2011; Parinet et al., 2010). A pilot-scale study is warranted to substantiate the theoretical optimum ratio of $0.35 \mathrm{H}_{2} \mathrm{O}_{2}: \mathrm{O}_{3}(\mathrm{mg} / \mathrm{mg}$ ) (Acero and von Gunten, 2001). Below this ratio, $\mathrm{O}_{3}$ is present in excess, which favors $\mathrm{O}_{3}$ decomposition over $\cdot \mathrm{OH}$ formation. Above this ratio, $\mathrm{H}_{2} \mathrm{O}_{2}$ is present in excess, and it consumes $\mathrm{O}_{3}$, generating $\cdot \mathrm{OH}$.

\subsection{Objectives}

This study investigated the effectiveness of advanced oxidation incorporating ozone $\left(\mathrm{O}_{3}\right)$ and hydrogen peroxide/ozone $\left(\mathrm{H}_{2} \mathrm{O}_{2} / \mathrm{O}_{3}\right)$ with biofiltration to assess the following objectives:

1. Evaluate biofiltration performance with and without pre-oxidation for geosmin, 2methylisoborneol (MIB), and DBP precursor removal efficiency.

2. Compare biologically active carbon with biologically active anthracite for T\&O control and removal of organics.

3. Assess the impact of advanced oxidation as well as investigate the performance of biofiltration with respect to DBP precursor reduction. 


\subsection{Description of Chapters}

- Chapter 2: provides background information about oxidative pre-treatment, and biofiltration.

- Chapter 3: describes experimental design, analytical methods, and statistical analysis.

- Chapter 4: compares impact of $\mathrm{O}_{3}$ and $\mathrm{H}_{2} \mathrm{O}_{2} / \mathrm{O}_{3}$ advanced oxidation alone and in combination with biofiltration for the removal of geosmin, MIB, and DBP precursors.

- Chapter 5: provides conclusion and recommendation.

- Chapter 6: contains a list of references used

- Chapter 7: contains appendices for calibration curves, QA/QC charts, and raw data. 


\section{Literature Review}

\section{$2.1 \quad \mathrm{O}_{3}$ Oxidation}

$\mathrm{O}_{3}$ reacts by two mechanisms - direct $\mathrm{O}_{3}$ or with hydroxyl radical $(\cdot \mathrm{OH})$ reaction (von Gunten, 2003). Direct $\mathrm{O}_{3}$ reaction is selective and occurs with electron-rich moieties mainly double bonds, aromatic phenols and amine functional groups, whereas hydroxyl radical oxidation is nonselective and has fast reaction rates with organics (Acero and von Gunten, 2001). As, advanced oxidation processes (AOPs) are based on enhanced formation of $\cdot \mathrm{OH}$, peroxide $\left(\mathrm{H}_{2} \mathrm{O}_{2}\right)$ addition can be cost efficient way for converting an ozone treatment into an AOP based treatment (Park et al., 2015). In this process, $\cdot \mathrm{OH}$ are generated by complex radical chain reaction, which consumes two $\mathrm{O}_{3}$ and one $\mathrm{H}_{2} \mathrm{O}_{2}$ to produce two $\cdot \mathrm{OH}$ (Hoigné and Bader, 1979). The overall reaction is shown in equation 2.1 .

$$
\mathrm{H}_{2} \mathrm{O}_{2}+2 \mathrm{O}_{3} \rightarrow 2 \cdot \mathrm{OH}+3 \mathrm{O}_{2}
$$

At the Peterborough Water Treatment Pilot Plant (PWTPP), $\mathrm{O}_{3}$ and $\mathrm{H}_{2} \mathrm{O}_{2} / \mathrm{O}_{3}$ advanced oxidation is applied prior to biofiltration for organics removal and disinfection by-product (DBP) precursor reduction.

\subsection{1 $\mathrm{O}_{3}$ and $\mathrm{H}_{2} \mathrm{O}_{2} / \mathrm{O}_{3}$ Advanced Oxidation in Water Treatment}

Geosmin and 2-methylisoborneol (MIB) have been typically reported as the two common T\&O compounds that are seasonally detected in source water supplies (Bruce and William, 2000). As a result of poor removal efficiency of these compounds through conventional treatment $(<20 \%)$ combined with their low odour threshold concentrations $(\sim 10 \mathrm{ng} / \mathrm{L})$, their occurrence in finished water is concern to municipalities (Srinivasan and Sorial, 2011). In recent years, $\mathrm{O}_{3}$ and $\mathrm{H}_{2} \mathrm{O}_{2} / \mathrm{O}_{3}$ have been increasingly applied to achieve multiple treatment objectives, including removal of $\mathrm{T} \& \mathrm{O}$ causing compounds. $\mathrm{O}_{3}$ dose of $1-3 \mathrm{mg} / \mathrm{L}$ and a minimum contact time of 10 to $15 \mathrm{~min}$ is typically used for the removal of geosmin and MIB for the concentrations present in natural water conditions (Park et al., 2007; Westerhoff et al., 2006). Although $\mathrm{O}_{3}$ has showed capability of oxidizing geosmin and $\mathrm{MIB}$, presence of $\mathrm{O}_{3}$ initiators, promoters, and scavengers determine the 
availability of $\mathrm{O}_{3}$ and $\bullet \mathrm{OH}$ for reaction. A list of common initiators, promoters and scavengers for $\mathrm{O}_{3}(\mathrm{or} \cdot \mathrm{OH})$ decomposition is shown in Table 2-1.

Table 2-1: Typical Initiators, Promoters, Scavengers for $\mathrm{O}_{3}$ Decomposition (Adapted and Modified from Sonntag and Gunten, (2012))

\begin{tabular}{|l|l|l|}
\hline Initiator & Promoter & Scavenger \\
\hline $\mathrm{OH}^{-}$ & humic acid & $\mathrm{HCO}_{3}{ }^{-} / \mathrm{CO}_{3}{ }^{2-}$ \\
\hline $\mathrm{H}_{2} \mathrm{O}_{2} / \mathrm{HO}_{2}^{-}$ & primary \& secondary alcohols & organics, $\mathrm{PO}_{4}{ }^{3-}$ \\
\hline $\mathrm{Fe}^{2+}$ & aryl-R & tertiary-butyl alcohol \\
\hline
\end{tabular}

Several studies investigated the impact of different experimental parameters $\left(\mathrm{O}_{3}\right.$ dose, $\mathrm{pH}$, temperature) to optimize $\mathrm{O}_{3}$ and $\mathrm{H}_{2} \mathrm{O}_{2} / \mathrm{O}_{3}$ advanced oxidation treatment process for geosmin and MIB removal. The $\mathrm{O}_{3}$ reaction mechanism with $\mathrm{NOM}$ was strongly dependent on $\mathrm{pH}$. At acidic water $\mathrm{pH}$ (5-7), organics were predominantly oxidized by $\mathrm{O}_{3}$, but at alkaline $\mathrm{pH}(7.5-9), \mathrm{O}_{3}$ decomposes into $\cdot \mathrm{OH}$, which becomes available for oxidation reactions. The influence of $\mathrm{pH}$ on $\mathrm{O}_{3}$ efficiency for geosmin and MIB removal was evaluated by several authors. Liang et al. (2007) investigated the impact of three $\mathrm{pH}\left(5\right.$ vs. 7 vs. 9) on $\mathrm{O}_{3}$ and observed higher geosmin (61\% vs. $90 \%$ vs. $99 \%$ ) and MIB (55\% vs. $86 \%$ vs. $98 \%$ ) removals with higher pH. Similar removal patterns were observed by others (Yuan et al., 2013; Westerhoff et al., 2006).

Previous studies have also reported impact of water temperature on the $\mathrm{O}_{3}$ efficiency (Knol et al., 2015). Increasing the temperature increases activation energy, thereby improving $\mathrm{O}_{3}$ efficiency (Gardoni et al., 2012). Elovitz et al. (2000) observed increased rate of $\mathrm{O}_{3}$ depletion (initial $\mathrm{O}_{3}$ dose $=1.0 \mathrm{mg} / \mathrm{L}$ ) when water temperature was increased from 5 to $35^{\circ} \mathrm{C}$. In contrast, rate of $\cdot \mathrm{OH}$ depletion was not observed to be impacted with increased temperature.

Another important parameter that can impact the efficiency is applied $\mathrm{O}_{3}$ dose (Gardoni et al., 2012; Lee et al., 2012). Higher applied $\mathrm{O}_{3}$ dose result in higher treatment costs that were associated with $\mathrm{O}_{3}$ generation and chemical addition for quenching the residual. Therefore it is necessary to optimize $\mathrm{O}_{3}$ dose. Previous studies have reported (40-70\%) geosmin and (30-60\%) MIB removals when applied with different $\mathrm{O}_{3}$ dose of $1.5-2 \mathrm{mg} / \mathrm{L}$ with a contact time of 8-10 min 
(Bruce and William, 2000; Carlson et al., 2007; Park et al., 2007). The impact of pH, temperature, and water matrix from previous studies is shown in Table 2-2.

Table 2-2: Summary of $\mathrm{O}_{3}$ Studies Characterizing the Impact of Water Matrix on Geosmin and MIB Oxidation

\begin{tabular}{|c|c|c|c|}
\hline Reference & $\begin{array}{l}\text { Study scale, } \\
\text { water matrix }\end{array}$ & $\begin{array}{l}\text { Experimental } \\
\text { conditions }\end{array}$ & Observed Removals \\
\hline $\begin{array}{l}\text { Yuan et al. } \\
\text { (2013) }\end{array}$ & $\begin{array}{l}\text { Bench-scale } \\
\text { Synthetic water }\end{array}$ & $\begin{array}{l}\mathrm{O}_{3}=4.2 \mathrm{mg} / \mathrm{L} ; \\
\mathrm{pH}=5.4,7.3,9.1\end{array}$ & $\begin{array}{l}\text { Higher geosmin }(>12 \%) \text { and MIB } \\
(>40 \%) \text { removals observed in } \\
\text { alkaline }(\mathrm{pH}=9) \text { conditions } \\
\text { compared to acidic conditions } \\
(\mathrm{pH}=5.4)\end{array}$ \\
\hline $\begin{array}{l}\text { Liang et al. } \\
\text { (2007) }\end{array}$ & $\begin{array}{l}\text { Bench-scale } \\
\text { Surface water }\end{array}$ & $\begin{array}{l}\mathrm{O}_{3}=0.35 \mathrm{mg} / \mathrm{L} \\
\mathrm{pH}=5,7,9 ; \\
\mathrm{TOC}=3 \mathrm{mg} / \mathrm{L}\end{array}$ & $\begin{array}{l}\text { GSM and MIB removals varied } \\
\text { from } 61 \% \text { to } 99 \% \text { and } 55 \% \text { to } \\
98 \% \text { when pH was increased } \\
\text { from } 5 \text { to } 9\end{array}$ \\
\hline $\begin{array}{l}\text { Westerhoff } \\
\text { et al. (2006) }\end{array}$ & $\begin{array}{l}\text { Bench-scale } \\
\text { Pure water and } \\
\text { surface water }\end{array}$ & $\begin{array}{l}\mathrm{O}_{3}=3 \mathrm{mg} / \mathrm{L} ; \\
\mathrm{pH}=8.0 ; \\
\mathrm{H}_{2} \mathrm{O}_{2} / \mathrm{O}_{3}=0.05(\mathrm{w} / \mathrm{w}) \\
\text { TOC }=4.9 \mathrm{mg} / \mathrm{L} ; \\
\text { Alkalinity }=150 \mathrm{mg} / \mathrm{L} \\
\text { as } \mathrm{CaCO}_{3}\end{array}$ & $\begin{array}{ll}\text { - } & \text { Direct oxidation by } \mathrm{O}_{3} \text { resulted in } \\
\text { low geosmin/MIB oxidation } \\
(<30 \%) \\
\text { - } \mathrm{H}_{2} \mathrm{O}_{2} \text { addition improved MIB } \\
\text { removal by } 24 \% \text { (from } 74 \% \text { to } \\
99 \% \text { ) }\end{array}$ \\
\hline $\begin{array}{l}\text { Acero et al. } \\
(2001)\end{array}$ & $\begin{array}{l}\text { Bench-scale } \\
\text { Ground and } \\
\text { surface water }\end{array}$ & $\begin{array}{l}\mathrm{O}_{3}=1 \mathrm{mg} / \mathrm{L} \\
\mathrm{pH}=7.0 \\
\mathrm{H}_{2} \mathrm{O}_{2} / \mathrm{O}_{3}=0.0,0.19 \\
0.34 .0 .70(\mathrm{w} / \mathrm{w}) \\
\mathrm{TOC}=3.2 \mathrm{mg} / \mathrm{L}\end{array}$ & $\begin{array}{l}\text { - } \% \text { pCBA elimination for } \\
\text { respective } \mathrm{H}_{2} \mathrm{O}_{2} / \mathrm{O}_{3} \text { ratios }=49 \% \text {, } \\
72 \%, 76 \%, 78 \% \\
\text { - Optimum } \mathrm{H}_{2} \mathrm{O}_{2} / \mathrm{O}_{3}(\mathrm{w} / \mathrm{w})=0.2- \\
0.3 \text { for maximum } \cdot \mathrm{OH} \text { formation }\end{array}$ \\
\hline $\begin{array}{l}\text { Elovitz et al. } \\
(2000)\end{array}$ & $\begin{array}{l}\text { Bench-scale } \\
\text { Pure water and } \\
\text { Lake water }\end{array}$ & $\begin{array}{l}\mathrm{O}_{3}=1 \mathrm{mg} / \mathrm{L} \\
\mathrm{pH}=6-8 \\
\mathrm{~T}=5-35^{\circ} \mathrm{C}\end{array}$ & $\begin{array}{l}\text { Increase in } \mathrm{pH} \& \mathrm{Temp} \text {. resulted } \\
\text { in increased rate of } \mathrm{O}_{3} \text { depletion } \\
\text { - Increase in alkalinity resulted in } \\
\text { increased rate of } \cdot \mathrm{OH} \text { depletion }\end{array}$ \\
\hline
\end{tabular}

Initial geosmin and MIB concentration $=100 \mathrm{ng} / \mathrm{L}$

$\mathrm{O}_{3}$ efficiency can be improved with the addition of $\mathrm{H}_{2} \mathrm{O}_{2}$ to produce hydroxyl radicals $(\cdot \mathrm{OH})$ with fast reaction rates for geosmin and $\mathrm{MIB}\left(\mathrm{K}_{\mathrm{OH}} \sim 10^{9} \mathrm{M}^{-1} \mathrm{~s}^{-1}\right)$ (Lee and von Gunten, 2016; Peter and von Gunten, 2007). Previous pilot studies have reported increases of 10-15\% in geosmin and MIB removals upon $\mathrm{H}_{2} \mathrm{O}_{2}$ addition (Glaze et al., 1990; Park et al., 2015; Wang et al., 2015). In addition, few previous studies reported varying $\mathrm{H}_{2} \mathrm{O}_{2} / \mathrm{O}_{3}$ ratio for optimal geosmin and MIB reduction with changing source waters. Optimal $\mathrm{H}_{2} \mathrm{O}_{2} / \mathrm{O}_{3}$ ratio ranging 0.1 to $0.2(\mathrm{mg} / \mathrm{mg})$ and 0.1 to 0.3 were reported by Ferguson et al (1990), while investigating two different source waters. 


\section{2 $\mathrm{O}_{3}$ and $\mathrm{H}_{2} \mathrm{O}_{2} / \mathrm{O}_{3}$ Prior to Biofiltration for Organics Removal}

\subsubsection{DOC Removal}

$\mathrm{O}_{3}$ and $\mathrm{H}_{2} \mathrm{O}_{2} / \mathrm{O}_{3}$ can achieve partial removal of dissolved organic carbon (DOC) by transforming larger molecular weight organics into lower molecular weight. Previous studies reported 3-10\% DOC removal when applied with $\mathrm{O}_{3}$ doses of 1-3 mg/L (Volk et al. 1997; Siddiqui et al. 1997). Further, $\mathrm{O}_{3}$ oxidation increases hydrophilic content present in the NOM, thereby decreasing the DOC content in the hydrophobic fraction (Treguer et al., 2010). The impact of peroxide addition on DOC reduction is ambiguous as few studies have shown no impact, whereas others have showed enhanced DOC reduction (Zha et al., 2016). Lamsal et al. (2010) reported DOC reduction of $6 \%$ and $10 \%$ when treated with $\mathrm{O}_{3}$ and $\mathrm{H}_{2} \mathrm{O}_{2} / \mathrm{O}_{3}$ advanced oxidation. Ozonation has also shown to improve the biodegradability of organics by transforming them into low molecular weight aldehydes and carboxylic acids that result in increased formation of rapid biodegradable organic carbon $\left(\mathrm{BDOC}_{\mathrm{r}}\right)\left(\right.$ Carlson et al 2001). These $\mathrm{BDOC}_{\mathrm{r}}$ formed can then be preferentially removed by biofiltration (Black and Berube 2014, Hozalski et al. 1999).

\subsubsection{DBP Precursor Removal}

Ozonation of water can result in reduction of trihalomethane (THM) and haloacetic acid (HAA) formation potentials (Chaiket et al. 2002). Previous studies with low ozone dose (0.5-1.0 $\mathrm{mg} / \mathrm{mg}$ DOC) did not observe significant (1-5\%) reductions in THM FP \& HAA FP when compared with conventional treatment (15-30\%) (Carlson and Amy 2001; McKie et al. 2015). Whereas, higher $\mathrm{O}_{3}$ dose (1.5-2.0 mg/mg DOC) reported reductions ranging from 30-60\% for both THM FP and HAA FP (Karnik et al. 2005, Vasyukova et al. 2013). This suggest that ozonation when combined with biofiltration may be effective treatment process for overall reductions in DBP precursors, but its applicability may be dependent on $\mathrm{O}_{3}$ dose optimization. Therefore, further research is needed to elucidate its applicability while optimising for organics removal and DBP formation potential reductions. Previous studies investigating the impact of $\mathrm{O}_{3}$ and $\mathrm{H}_{2} \mathrm{O}_{2} / \mathrm{O}_{3}$ oxidation on biofiltration have been summarized in Table 2-3. 
Table 2-3: Impact of $\mathrm{O}_{3}$ and $\mathrm{H}_{2} \mathrm{O}_{2} / \mathrm{O}_{3}$ Oxidation on Biofiltration

\begin{tabular}{|c|c|c|c|}
\hline Reference & $\begin{array}{l}\text { Scale, Source, } \\
\text { Filter media, \& } \\
\text { EBCT(min) }\end{array}$ & $\begin{array}{l}\text { O3: } \mathrm{DOC} \\
\text { ratio or } \\
\mathrm{H}_{2} \mathrm{O}_{2} / \mathrm{O}_{3} \text { ratio }\end{array}$ & Observed Removals (\%) \\
\hline Carlson et al. (2001) & $\begin{array}{l}\text { Pilot - scale, River } \\
\text { water, Anthracite, } \\
\text { EBCT (5.4) }\end{array}$ & $0.6: 1$ & DOC (10-15\%) \\
\hline Chaiket et al. (2002) & $\begin{array}{l}\text { Pilot-scale, River } \\
\text { water, GAC-sand, } \\
\text { Anthracite-sand }\end{array}$ & $1: 1$ & $\begin{array}{l}\text { DOC (18\%) } \\
\mathrm{UV}_{254}(16-61 \%)\end{array}$ \\
\hline $\begin{array}{l}\text { Black \& Bèrubè } \\
(2014)\end{array}$ & $\begin{array}{l}\text { Bench-scale, Tap } \\
\text { water, GAC media, } \\
\text { EBCT }(20)\end{array}$ & $\begin{array}{l}1: 1 \\
2: 1\end{array}$ & $\begin{array}{l}\text { DOC }(\sim 3 \%) \\
\text { BDOC }(13 \%) \\
\text { SUVA }(28 \%) \\
\end{array}$ \\
\hline $\begin{array}{l}\text { Pharand et al. } \\
\text { (2015) }\end{array}$ & $\begin{array}{l}\text { Full-scale, River } \\
\text { water, Anthracite- } \\
\text { sand, EBCT (38) }\end{array}$ & $0.5: 1$ & DOC $(15 \%)$ \\
\hline Irabelli et al. (2008) & $\begin{array}{l}\text { Pilot-scale Detroit } \\
\text { River DOC }(3.4 \\
\text { mg/L) }\end{array}$ & $\begin{array}{l}\mathrm{H}_{2} \mathrm{O}_{2} / \mathrm{O}_{3} \text { ratio } \\
(0.1,0.2,0.35 \\
\mathrm{mg} / \mathrm{mg}) \mathrm{O}_{3} \\
\text { dose }(2.0 \mathrm{mg} / \mathrm{L}) \\
\end{array}$ & $\begin{array}{l}\text { DOC: } \mathrm{H}_{2} \mathrm{O}_{2} / \mathrm{O}_{3}(45 \%), \mathrm{O}_{3}(40 \%) \\
\mathrm{H}_{2} \mathrm{O}_{2} / \mathrm{O}_{3} \text { observed no impact on } \\
\text { THM and HAA FP reduction } \\
\text { compared to } \mathrm{O}_{3}\end{array}$ \\
\hline Lamsal et al. (2011) & $\begin{array}{l}\text { Bench-scale French } \\
\text { River DOC }(2.8 \\
\text { mg/L) }\end{array}$ & $\begin{array}{l}\mathrm{H}_{2} \mathrm{O}_{2}(23 \\
\mathrm{mg} / \mathrm{L}) \mathrm{O}_{3}(4.0 \\
\mathrm{mg} / \mathrm{L})\end{array}$ & $\begin{array}{l}\mathrm{DOC}: \mathrm{O}_{3}(6 \%), \mathrm{H}_{2} \mathrm{O}_{2} / \mathrm{O}_{3}(10 \%) \\
\mathrm{H}_{2} \mathrm{O}_{2} / \mathrm{O}_{3} \text { observed decreased } \\
\text { THM and HAA formation } \\
\text { potential compared to } \mathrm{O}_{3}\end{array}$ \\
\hline
\end{tabular}

\subsection{Research Gaps}

Preozonation $\left(\mathrm{O}_{3}\right.$ dose $\left.=1-2 \mathrm{mg} / \mathrm{L}\right)$ can be an effective treatment technology in removing geosmin (50-70\%) and MIB (50-70\%). However, water quality factors such as $\mathrm{pH}$, organic content, alkalinity, and temperature have shown to influence removals. In addition, selection of $\mathrm{O}_{3}$ dose also play an important role in oxidizing these compounds. Use of $\mathrm{H}_{2} \mathrm{O}_{2} / \mathrm{O}_{3} \mathrm{AOP}$ have shown to improve geosmin and MIB removal efficiencies by 10-15\% (Park et al., 2015; Li et al., 2010a; Mizuno et al., 2011). For maximum removals, optimal $\mathrm{H}_{2} \mathrm{O}_{2} / \mathrm{O}_{3}$ ratio for each water matrix should be tested (Acero et al., 2001). Elevated $\mathrm{H}_{2} \mathrm{O}_{2}$ concentration can rapidly decompose $\mathrm{O}_{3}$ into hydroxyl radicals, which react with organics and bicarbonates (Glaze et al. 1990). As a result, the effectiveness on removing geosmin and MIB is impacted. Acero et al. (2011) found that $\mathrm{H}_{2} \mathrm{O}_{2} / \mathrm{O}_{3}$ ratio of 0.34 resulted in optimum decomposition of a test compound, pCBA. The study observed no significant difference in pCBA decomposition when $\mathrm{H}_{2} \mathrm{O}_{2} / \mathrm{O}_{3}$ ratios was elevated from 0.34 to 
0.70. In 1990, Ferguson et al. observed nearly $10 \%$ decrease in geosmin removals when $\mathrm{H}_{2} \mathrm{O}_{2} / \mathrm{O}_{3}$ ratio was increased from 0.2 to 0.3 at an ozone dose of $2.0 \mathrm{mg} / \mathrm{L}$. Further, when $\mathrm{H}_{2} \mathrm{O}_{2} / \mathrm{O}_{3}$ is applied prior to biofiltration, synergistic effects could result in high removals than when used as a standalone treatments. Therefore, site-specific pilot-studies need to be conducted to optimize selection of $\mathrm{H}_{2} \mathrm{O}_{2} / \mathrm{O}_{3}$ ratios. 


\section{Materials and Methods}

\subsection{Experimental Configuration}

\subsubsection{Pilot Plant Configuration}

The Peterborough Water Treatment Plant (PWTP) is located on the Otonabee River and has a total capacity of 104 MLD. The pilot-plant was located within PWTP and consisted of a biofiltration and an ozone pilot; details of these pilots are provided in section 3.1.2 and 3.1.3, respectively. Pilot-scale studies were conducted using full-scale plant (FSP) settled water from the PWTP post coagulation, flocculation, and settling. The details of the raw and pilot plant influent water quality is provided in the Table $3-1$.

Table 3-1: Summary of Raw and Pilot Plant Influent (Settled) Water Quality

\begin{tabular}{|c|c|c|}
\hline Parameter & Raw Water & Settled Water \\
\hline $\mathrm{pH}$ & $8.0-8.2$ & $7.1-7.3$ \\
\hline Temperature $\left({ }^{\circ} \mathrm{C}\right)$ & $9-23$ & $9-22$ \\
\hline Turbidity $(\mathrm{NTU})$ & $0.332-0.775$ & $0.127-0.185$ \\
\hline DOC $(\mathrm{mg} / \mathrm{L})$ & $5.0-5.2$ & $3.0-3.3$ \\
\hline $\mathrm{UV}_{254}\left(\mathrm{~cm}^{-1}\right)$ & $0.10-0.11$ & $0.05-0.06$ \\
\hline Alkalinity $(\mathrm{mg} / \mathrm{L} \mathrm{as} \mathrm{CaCO} 3)$ & $67-79$ & $15-24$ \\
\hline GSM $(\mathrm{ng} / \mathrm{L})$ & $17-24$ & $11-20$ \\
\hline MIB $(\mathrm{ng} / \mathrm{L})$ & $13-21$ & $69-85$ \\
\hline THM FP $(\mu \mathrm{g} / \mathrm{L})$ & $156-184$ & $75-108$ \\
\hline HAA FP $(\mu \mathrm{g} / \mathrm{L})$ & $95-157$ & \\
\hline
\end{tabular}

\subsubsection{Biofiltration Pilot}

The biofiltration pilot consist of six parallel filter columns. These columns were operated in parallel at an EBCT of 10 min to match full-scale conditions. Three filters contained $50 \mathrm{~cm}$ of sand (effective size $\left(\mathrm{d}_{10}\right)=0.5$, uniformity coefficient $(\mathrm{UC})=1.8$ ) and $50 \mathrm{~cm}$ of biological 
exhausted GAC (Filtrasorb® 300 Calgon Carbon; Pittsburgh, PA) which had been in operation for 12 years and was assumed to be exhausted in terms of adsorptive capacity. The remaining three filters contained $50 \mathrm{~cm}$ of sand $\left(\mathrm{d}_{10}=0.5, \mathrm{UC}=1.8\right)$ and $50 \mathrm{~cm}$ of anthracite $\left(\mathrm{d}_{10}=0.85, \mathrm{UC}=\right.$ 1.8), which was obtained from the full-scale PWTP. All filters were operated at constant head and declining flow rate, with a water level maintained at $90 \mathrm{~cm}$ above the media. In order to maintain conditions conducive to biological filtration, five of the filters were backwashed with their individual (unchlorinated) effluent, while the conventional filter was backwashed with chlorinated water (chlorine residual $=1.5 \mathrm{mg} / \mathrm{L}$ ) from the FSP.

\subsubsection{Ozone and $\mathrm{H}_{2} \mathrm{O}_{2} / \mathrm{O}_{3}$ Pilot}

The $\mathrm{O}_{3}$ pilot consisted of two parallel trains ( 4 contactors of $65 \mathrm{~L}$ each; 2 contactors connected in series), supplied with full-scale settled water, and operated at a flow rate of $11 \mathrm{~L} / \mathrm{min}$ to achieve an $\mathrm{O}_{3}$ contact time of 12 minutes. Based on $\mathrm{O}_{3}$ demand tests conducted using settled water, $2 \mathrm{mg} / \mathrm{L} \mathrm{O}_{3}$ was applied. The selected dose corresponded to a $\mathrm{O}_{3}$ :DOC ratio of 0.625 , and within an operational range of $\mathrm{O}_{3}$ dosages $\left(\mathrm{O}_{3}: \mathrm{DOC}=0.5\right.$ to 1$)$ for optimal organics removal (Schulz, 2014; Zimmermann et al., 2011). For geosmin and MIB spiking trials, an influent concentration of $100 \mathrm{ng} / \mathrm{L}$ was targeted (Ferguson et al., 1990; Liang et al., 2014). The compounds were spiked continuously for 24 hours to simulate transient T\&O events using a Masterflex L/S pump. $\mathrm{H}_{2} \mathrm{O}_{2}$ was added immediately prior to $\mathrm{O}_{3}$ to obtain mass $\mathrm{H}_{2} \mathrm{O}_{2}: \mathrm{O}_{3}$ ratios of $0.1: 1,0.2: 1$, 0.35:1, and 0.5:1 mg/mg. Residual oxidants were quenched at the exit of the $\mathrm{O}_{3}$ pilot using calcium thiosulphate (CTS) at a molar ratio of CTS: $\mathrm{O}_{3}=4: 1$.

\subsubsection{Experimental Design}

This study was divided into four experimental conditions as presented in Figure 3-1. In the first condition, geosmin, MIB, and DBP precursor removals were evaluated across the conventional and biological filters with two different media (BAF vs. BAC) without the use of pre-oxidation. In the second condition, the impact of $0.1 \mathrm{H}_{2} \mathrm{O}_{2} / \mathrm{O}_{3}$ and $\mathrm{O}_{3}$ were compared as standalone treatments and as pre-treatments to BAF and BAC. In the third condition, the impact of $0.2 \mathrm{H}_{2} \mathrm{O}_{2} / \mathrm{O}_{3}$ was compared to $\mathrm{O}_{3}$. In the fourth condition, two AOP treatments $(0.35$ and 0.5 $\mathrm{H}_{2} \mathrm{O}_{2} / \mathrm{O}_{3}$ ) were evaluated in parallel. 


\section{Condition 1}

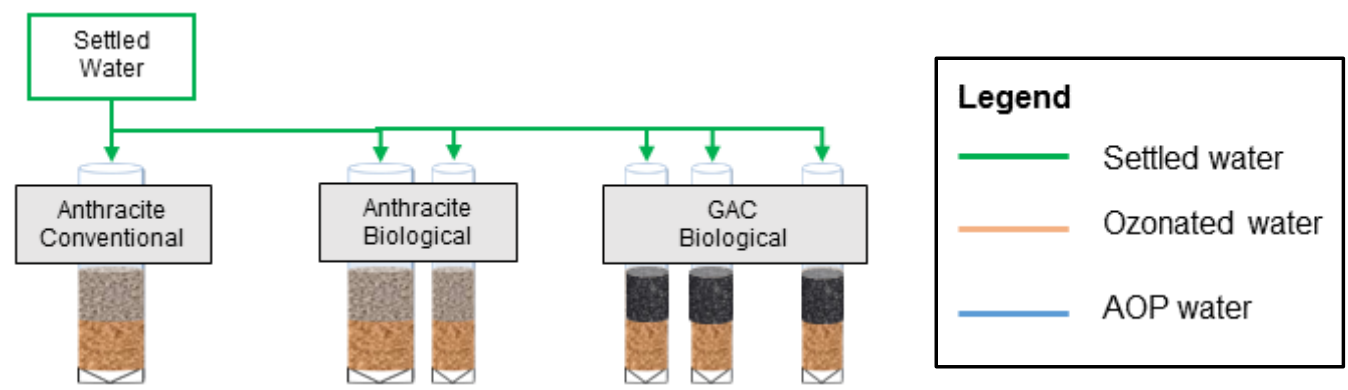

Condition 2

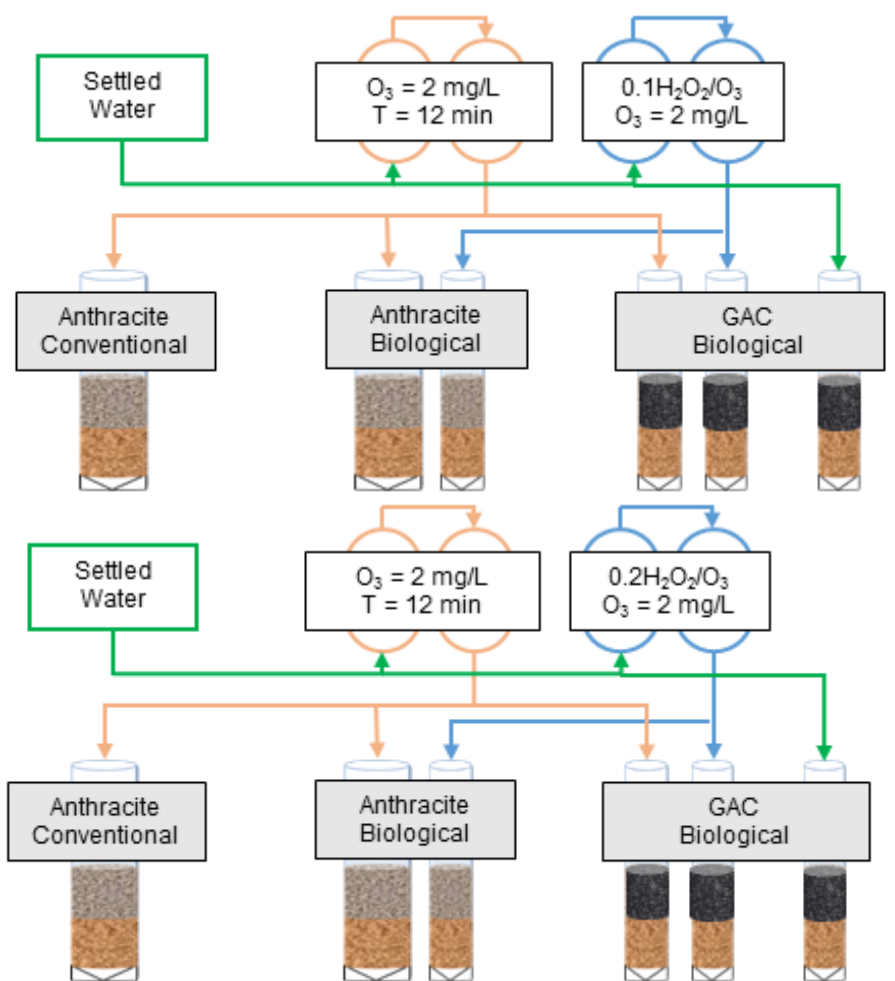

Condition 4

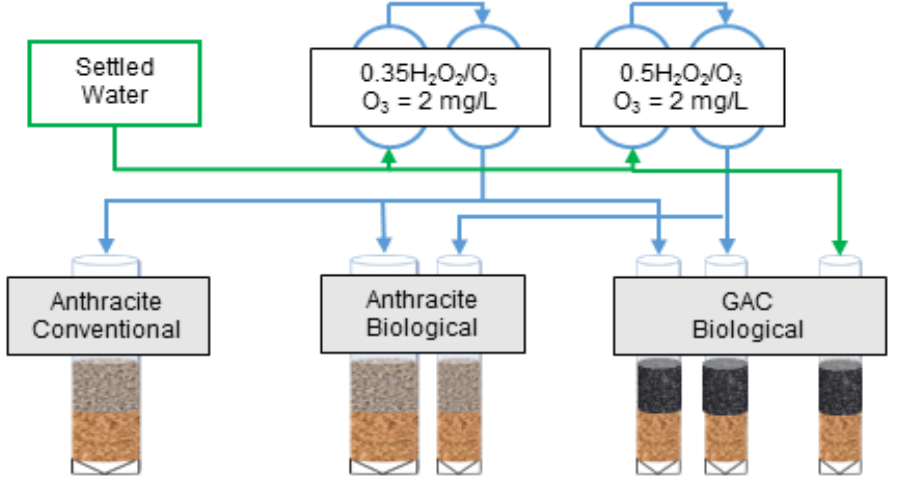

Figure 3-1: Pilot Plant Schematic for Experimental Condition 1, 2, 3, and 4 


\subsubsection{Spike and Sampling Procedure}

In total, four spike/sampling events were conducted during the months of September, October, and November. Geosmin and MIB samples were collected prior to and immediately after each treatment step to determine removal efficiency. For the condition 1 (when no pre-oxidation was applied), the T\&O compounds were spiked into the settled water line immediately prior to each filter. For conditions 2, 3 and 4, T\&O compounds were spiked prior to ozonation.

\subsection{Analytical Methods}

\subsubsection{ATP Analysis}

Adenosine triphosphate (ATP) analysis was conducted using a Luminultra analysis kit (DSA-100C). Media samples were obtained from the top 5-10 cm of the biofilter and analyzed as per the manufacturer's instructions provided in Appendix Table 7-1.

\subsubsection{Dissolved Organic Carbon}

DOC was measured based on standard method 5310 D using an O-I Corporation Model 1010 Analytical TOC Analyzer with a Model 1051 Vial Multi-Sampler (APHA, 2005). Samples were filtered into $40 \mathrm{~mL}$ amber vials through a $0.45 \mu \mathrm{m}$ glass fiber filter, and acidified to $\mathrm{pH} \leq 2$ using concentrated sulfuric acid if samples were not analyzed immediately after preparation. The vials were sealed with Teflon ${ }^{\circledR}$-lined septum screw caps and stored at $4{ }^{\circ} \mathrm{C}$. All samples were prepared on the day of collection and tested within 7 days. A summary of the instrument conditions are presented in Table 3-2. DOC concentrations were quantified using anhydrous potassium hydrogen phthalate (KHP) in Milli-Q® water as a calibration solution.

The calibration solutions were prepared at a concentration of $10 \mathrm{mg} / \mathrm{L}$ and diluted by the instrument to concentrations of $0,0.625,1.25,2.5$ and $5 \mathrm{mg} / \mathrm{L}$ for a 6-point calibration curve. A $10 \mathrm{mg} / \mathrm{L}$ calibration sample was prepared, diluted and analyzed before each sample set. A sample calibration curve is shown in Appendix Figure 7-1. Check standards $(C=5 \mathrm{mg} / \mathrm{L})$ were tested after every 10 samples, and at the end of every sample set. Additionally, a minimum of three blank samples were tested after calibration, and before every check standard sample. The reagent list is shown in Table 3-3 and sample analysis procedure is presented in Appendix Table 7-2 
Table 3-2: DOC Analyzer Conditions

\begin{tabular}{|l|l|}
\hline Parameter & Description \\
\hline Acid volume & $200 \mu \mathrm{L}$ of $5 \%$ phosphoric acid \\
\hline Oxidant volume & $1000 \mu \mathrm{L}$ of $100 \mathrm{~g} / \mathrm{L}$ sodium persulphate \\
\hline Sample volume & $15 \mathrm{~mL}$ \\
\hline Rinses per sample & 1 \\
\hline Volume per rinse & $15 \mathrm{~mL}$ \\
\hline Replicates per sample & 3 \\
\hline Reaction time (min:sec) & TIC 2:00; TOC 2:30 \\
\hline Detection time (min:sec) & TIC 2:40; TOC 2:00 \\
\hline Purge gas & Nitrogen \\
\hline Loop size & $5 \mathrm{~mL}$ \\
\hline
\end{tabular}

Table 3-3: DOC Analysis Reagents

\begin{tabular}{|l|l|}
\hline Reagent & Supplier and purity \\
\hline Milli-Q® water & Prepared in the laboratory \\
\hline Sulphuric acid, $\mathrm{H}_{2} \mathrm{SO}_{4}$ & VWR International, 98\%+ \\
\hline Sodium persulphate, $\mathrm{Na}_{2}\left(\mathrm{SO}_{4}\right)$ & Sigma Aldrich, 98\%+, anhydrous \\
\hline Potassium hydrogen phthalate (KHP), $\mathrm{C}_{8} \mathrm{H}_{5} \mathrm{KO}_{4}$ & Sigma Aldrich, 98\%+ \\
\hline Phosphoric acid, $\mathrm{H}_{3} \mathrm{PO}_{4}$ & Caledon, $>85 \%$ \\
\hline
\end{tabular}




\subsubsection{Geosmin and MIB}

Geosmin (CAS\# 16423-19-1) and MIB (CAS\# 2371-42-8) were purchased from Dalton Pharma Services in Toronto. Samples were extracted using the solid phase micro-extraction (SPME) fiber and analyzed using Gas Chromatography (Varian 3800) with Mass Spectroscopy (Varian 400) operated in electron ionization (EI) mode according to Standard Method 6040D. Details pertaining to the sample extraction, preparation, calibration, and analysis procedure are presented in Appendix Table 7-3. Sample calibration curve for both geosmin and MIB are presented in Appendix Figure 7-2. Check standards $(\mathrm{C}=60 \mathrm{ng} / \mathrm{L})$ were tested after every 10 samples, and at the end of every sample set. A blank was tested before every check standard.

\subsubsection{UV 254}

$\mathrm{UV}_{254}$ is a measure of ultraviolet absorbance at wavelengths of $254 \mathrm{~nm}$, and can be used to approximate the concentration of organic materials in a water sample. Samples were placed in 1 cm quartz cell (Hewlett Packard, Mississagua) and measured using a CE 3055 Single Beam Cecil UV/Visible Spectrophotometer (Cambridge, England). The device was zeroed with Milli-Q® water. The cells were rinsed with Milli-Q ${ }^{\circledR}$ water twice between sampling and rinsed again with the sample water before analysis to minimize contamination.

\subsubsection{LC-OCD}

Liquid chromatography-organic carbon detection (LC-OCD) characterized the organic compounds found in raw and treated water samples. LC-OCD identifies five different fractions of DOC including: biopolymers, humic substances, building blocks, low molecular weight acids, and low molecular weight neutrals (Huber et al., 2011).

Water samples were filtered using a $0.45 \mu \mathrm{m}$ glass fiber filter (Gelman Supor, Gelman Sciences, Ann Arbor, MI) and collected in $40 \mathrm{~mL}$ amber glass vials with Teflon ${ }^{\circledR}$ lined silicon septa and screw caps (VWR International, Mississauga, ON). The samples were stored at $4^{\circ} \mathrm{C}$ until being shipped to the University of Waterloo (Waterloo, ON) for analysis. Based on a method by Huber et al. (2011), the samples are first separated chromatographically using a weak cation exchange column (250 mm x $20 \mathrm{~mm}$, Tosoh, Japan). The mobile phase used was a phosphate buffer exposed to UV irradiation in an annular UV reactor, delivered at a flow rate of $1.1 \mathrm{~mL} / \mathrm{min}$ 
to an autosampler (MLE, Dresden, Germany, 1 mL injection volume). Chromatographic separation was followed by $\mathrm{UV}_{254}$ detection (UVD), and organic carbon detection (OCD). The solution was acidified to form carbonic acid from carbonates at the OCD inlet. Total DOC for each sample was measured using a column bypass. Calibration was completed using a potassium hydrogen phthalate (KHP) solution. Data processing and acquisition was completed using a custom ChromCALC software package (Karlsruhe, Germany).

\subsubsection{Disinfection By-Product Formation Test}

For DBP formation potential, uniform formation condition (UFC) test was employed where samples were chlorinated in duplicate to achieve a free chlorine target residual of $1.5 \pm 0.5 \mathrm{mg} / \mathrm{L}$ after $24 \pm 2$ hours at $20^{\circ} \mathrm{C}$ and $\mathrm{pH}$ was not adjusted in order to match the full-scale. If the residual chlorine concentration was correct after 24 hours, the disinfectant in each sample was quenched with $20 \mathrm{mg}$ of $\mathrm{L}$-ascorbic acid. The bottles were then acidified to $\mathrm{pH} 2$ with $\mathrm{H}_{2} \mathrm{SO}_{4}$ and stored in the dark at $4{ }^{\circ} \mathrm{C}$ until extraction.

\subsubsection{Trihalomethanes (THMs)}

Trihalomethane analysis was conducted to quantify the concentration of four compounds: chloroform (trichloromethane; TCM), bromodichloromethane (BDCM), dibromochloromethane (DBCM), and bromoform (tribromomethane; TBM). A liquid-liquid extraction with gas chromatography was performed based on Standard Method 6232 B (APHA, 2005). The analysis was conducted at the University of Toronto drinking water research laboratory (Toronto, Ontario) using a Hewlett Packard 5890 Series II Plus gas chromatograph (Mississauga, Ontario) equipped with an electron capture detector (GC-ECD) and a DB 5.625 capillary column (Agilent 30 Technologies Canada Inc., Mississauga, Ontario). A THM stock solution (2000 $\mu \mathrm{g} / \mathrm{mL})$ was used to create an intermediate solution $(20 \mathrm{mg} / \mathrm{L})$. This intermediate was used to generate calibration standards of $0,5,10,20,40,60,80,100 \mu \mathrm{g} / \mathrm{L}$. Sample calibration curve of all the compounds is shown in Appendix Figure 7-3. The instrument conditions and required reagents are presented in Table 3-4 and Table 3-5, respectively. 
Table 3-4: THM Instrument Conditions

\begin{tabular}{|l|l|}
\hline Parameter & Description \\
\hline Injector Temperature & $200^{\circ} \mathrm{C}$ \\
\hline Detector Temperature & $300^{\circ} \mathrm{C}$ \\
\hline & $40^{\circ} \mathrm{C}$ for 4.0 min \\
Temperature Program & $4{ }^{\circ} \mathrm{C} /$ min temperature ramp to $95^{\circ} \mathrm{C}$ \\
& $60^{\circ} \mathrm{C} / \mathrm{min}$ temperature ramp to $200^{\circ} \mathrm{C}$ \\
\hline Carrier Gas & Helium \\
\hline Flow Rate & $1.2 \mathrm{~mL} / \mathrm{min}$ at $35^{\circ} \mathrm{C}$ \\
\hline
\end{tabular}

Table 3-5: THM Reagent Compounds

\begin{tabular}{|l|l|}
\hline Reagent & Source \\
\hline Milli-Q® water & Prepared in the laboratory \\
\hline $\begin{array}{l}\text { Concentrated trihalomethane stock for } \\
\text { calibration }\end{array}$ & $\begin{array}{l}\text { Supelco, } 2000 \mu \mathrm{g} / \mathrm{mL} \text { in methanol } \\
(48140-\mathrm{U})\end{array}$ \\
\hline Sodium sulphate $\left[\mathrm{Na}_{2} \mathrm{SO}_{4}\right]$ & Sigma Aldrich, ACS Grade \\
\hline Methyl-tert-butyl-ether (MTBE) & Fluka, $>99.8 \%$ \\
\hline
\end{tabular}

\subsubsection{Haloacetic Acids (HAAs)}

The analysis of haloacetic acids (HAAs) involved quantifying the following 9 compounds: monochloroacetic acid (MCAA), monobromoacetic acid (MBAA), dichloroacetic acid (DCAA), trichloroacetic acid (TCAA), bromochloroacetic acid (BCAA), dibromoacetic acid (DBAA), bromodichloroacetic acid (BDCAA), dibromochloroacetic acid (DBCAA), and tribromoacetic acid (TBAA). The analysis was completed using a liquid-liquid extraction and a gas chromatograph based on Standard Method 6251 B (APHA, 2005). The analyses were completed at the University of Toronto drinking water research laboratory (Toronto, Ontario) using a Hewlett Packard 5890 Series II Plus gas chromatograph (Mississauga, Ontario) paired with an electron capture detector (GC-ECD) and a DB 5.625 capillary column (Agilent Technologies Canada Inc., Mississauga, Ontario). Details pertaining to the analysis reagents and instrument conditions is presented in Table 3-6 and Table 3-7, respectively. 
Table 3-6: HAA Reagent Compounds

\begin{tabular}{|c|c|}
\hline Reagent & Source \\
\hline Diethyl ether $\left[\mathrm{C}_{2} \mathrm{H}_{5} \mathrm{OCH}_{2} \mathrm{CH}_{2} \mathrm{OCH}_{2} \mathrm{CH}_{2} \mathrm{OH}\right]$ & Sigma Aldrich, $99+\%$ \\
\hline $\begin{array}{l}\text { N-Methyl-N-nitroso-p-toluene sulfonamide } \\
\text { (Diazald) } \\
{\left[\mathrm{CH}_{3} \mathrm{C}_{6} \mathrm{H}_{4} \mathrm{SO}_{2} \mathrm{~N}\left(\mathrm{CH}_{3}\right) \mathrm{NO}\right]}\end{array}$ & Sigma Aldrich, $99+\%$ \\
\hline Potassium Hydroxide (KOH) & BDH, $85.0+\%$, ACD Grade \\
\hline Sulphuric acid $\left[\mathrm{H}_{2} \mathrm{SO}_{4}\right]$ & E.M. Science, $98+\%$ \\
\hline Haloacetic acids concentrated stock & EPA 552.2 Acids Calibration Mix in MTBE \\
\hline Sodium sulphate $\left[\mathrm{Na}_{2} \mathrm{SO}_{4}\right]$ & Sigma Aldrich, ACS Grade \\
\hline Methyl-tert-butyl-ether (MTBE) & Sigma Aldrich, $>99.8 \%$ \\
\hline
\end{tabular}

Table 3-7: HAA Instrument Conditions

\begin{tabular}{|l|l|}
\hline Parameter & Description \\
\hline Injector Temperature & $200^{\circ} \mathrm{C}$ \\
\hline Detector Temperature & $300^{\circ} \mathrm{C}$ \\
\hline & $35^{\circ} \mathrm{C}$ for 10.0 min \\
& $\begin{array}{l}2.5^{\circ} \mathrm{C} / \text { min temperature ramp to } 65^{\circ} \mathrm{C} \\
10^{\circ} \mathrm{C} / \mathrm{min} \text { temperature ramp to } 85^{\circ} \mathrm{C} \\
20^{\circ} \mathrm{C} / \mathrm{min} \text { temperature ramp to } 205^{\circ} \mathrm{C}, \text { hold for } 7 \text { minutes }\end{array}$ \\
\hline Temperature Program & Helium \\
\hline Carrier Gas & $1.2 \mathrm{~mL} / \mathrm{min}$ at $35^{\circ} \mathrm{C}$ \\
\hline
\end{tabular}




\subsection{Statistical Analysis}

All comparisons between treatments were conducted using a paired Student t-test (95\% significance level). A two-tailed test was used where the objective was to identify whether a difference existed between two treatments (e.g. comparison of two control biofilters), while a single-tailed test was used to determine whether a particular treatment performed better than the other treatment strategy (e.g. comparison of two pre-oxidation strategies $\mathrm{O}_{3}$ and $\mathrm{H}_{2} \mathrm{O}_{2} / \mathrm{O}_{3}$ ) as

described by McKie et al. (2015). Reported p-values indicate the level at which difference between two treatments were statistically significant. 


\section{Ozone/Peroxide Advanced Oxidation in Combination with Biofiltration for Taste and Odour Control and Organics Removal}

\subsection{Introduction}

Geosmin and 2-methylisoborneol (MIB) have typically been reported as the most common taste and odour $(\mathrm{T} \& \mathrm{O})$ causing compounds and are seasonally detected in drinking water sources as a result of anthropogenic or biogenic factors (Srinivasan and Sorial, 2011). Removal of these compounds by conventional treatment is low (geosmin: $<20 \%$; MIB: $<15 \%$ ) and their presence in finished water is a major concern to water treatment utilities (Olsen et al., 2016; Parinet et al., 2010).

Treatment strategies designed to remove geosmin and MIB from source waters have been intensively studied (Antonopoulou et al., 2014; Srinivasan and Sorial, 2011). Adsorption by granular activated carbon (GAC) has proven to be effective for the removal of these compounds, however it's efficiency is dependent on media adsorptive capacity (Gillogly et al., 1999; Ho and Newcombe, 2010). Fortunately, when the adsorptive capacity of GAC is exhausted, filters can be operated in a biological mode and continue to remove geosmin (44-87\%) and MIB (32-51\%), resulting in significant capital cost savings associated with media regeneration or replacement (Elhadi et al., 2004; Zhu et al., 2010). In addition, BAC has been recognized for its ability to reduce biodegradable organic matter (Carlson and Amy, 2001) and disinfection by-product (DBP) precursors (Zha et al., 2016). However, BAC performance is impacted by water temperature (Emelko et al., 2006; Moll et al., 1999), empty bed contact time (EBCT), and accumulation of attached microbial biomass (Elhadi et al., 2006). Because of these factors, BAC performance in terms of geosmin, MIB, as well as DBP precursor removals can vary significantly (de Vera et al., 2016; Elhadi et al., 2004; Guo et al., 2016).

Application of $\mathrm{O}_{3}$ prior to biofiltration has been shown to be effective for the removal of geosmin, MIB, and DBP precursors (Klausen and Grønborg, 2010; Park et al., 2015; Sánchez-Polo et al., 2006; Yan et al., 2010). An investigation of $\mathrm{O}_{3}$-biofiltration treatment at full-scale by Nerenberg et al. (2000) reported MIB removals of $36-54 \%$ by ozonation $\left(1.3 \mathrm{mg} / \mathrm{L} \mathrm{O}_{3}\right)$ followed by $26-46 \%$ removal across biofiltration (17 min EBCT). Chaiket et al. (2002) reported reductions 
of $18 \%$ dissolved organic carbon (DOC), $61 \% \mathrm{UV}_{254}$ absorbance, $17 \%$ trihalomethane formation potential (THMFP), and 19\% haloacetic acid formation potential (HAAFP) when treated with 3 $\mathrm{mg} / \mathrm{L} \mathrm{O}_{3}$ followed by BAC (5 min EBCT). It is important to note that $\mathrm{O}_{3}$ efficiency is dependent on source water characteristics such as pH, DOC, alkalinity, and temperature (Westerhoff et al., 2006), and can be improved with the addition of $\mathrm{H}_{2} \mathrm{O}_{2}$ to produce hydroxyl radicals $(\cdot \mathrm{OH})$ with fast reaction rates for geosmin and $\operatorname{MIB}\left(\mathrm{K}_{\mathrm{OH}} \sim 10^{9} \mathrm{M}^{-1} \mathrm{~s}^{-1}\right)$ (Lee and von Gunten, 2016; Peter and von Gunten, 2007). Previous pilot studies have reported increases of 10-15\% in geosmin and MIB removals upon $\mathrm{H}_{2} \mathrm{O}_{2}$ addition (Glaze et al., 1990; Park et al., 2015; Wang et al., 2015). However, much of the existing information regarding $\mathrm{H}_{2} \mathrm{O}_{2} / \mathrm{O}_{3}$ optimization has been based on the benchscale studies (Li et al., 2012; Mizuno et al., 2011; Parinet et al., 2010; Westerhoff et al., 2006; Yuan et al., 2013; Zhou et al., 2011). A pilot-scale study is warranted to substantiate the theoretical optimum of $0.35 \mathrm{H}_{2} \mathrm{O}_{2}: \mathrm{O}_{3}(\mathrm{mg} / \mathrm{mg}$ ) proposed by Acero and von Gunten, (2001). Below this ratio, $\mathrm{O}_{3}$ is present in excess, which favors $\mathrm{O}_{3}$ decomposition over $\cdot \mathrm{OH}$ formation. Above this ratio, $\mathrm{H}_{2} \mathrm{O}_{2}$ is present in excess, which it consumes $\mathrm{O}_{3}$, generating $\cdot \mathrm{OH}$.

$\mathrm{H}_{2} \mathrm{O}_{2} / \mathrm{O}_{3}$ mass ratios of $0.1: 1,0.2: 1,0.35: 1$, and 0.5:1 were compared to $\mathrm{O}_{3}$ alone to better understand the removal of geosmin, MIB, and organics at pilot-scale. The impact of pre-oxidation on subsequent biofiltration performance was also assessed with respect to the same analytes, as well as organic carbon removal (measured as DOC, $\mathrm{UV}_{254}$ ), DBP precursor removal (including precursors to THMs and HAAs), and filter media adenosine triphosphate (ATP). Liquid chromatography-organic carbon detection (LC-OCD) was performed to further characterize the impact of each treatment process and to explore potential relationships between the organic fractions (humics or low molecular weight compounds) and DBP precursor removal.

\subsection{Materials and Methods}

\subsubsection{Source Water}

Pilot-scale biofiltration studies were conducted using water from Otonabee River in Peterborough, Ontario. As the PWTP typically observes geosmin (15-22 ng/L) and MIB (10-20 ng/L) during September to November (PWTP, 2015), pilot-scale studies were conducted during 
these months using full-scale plant (FSP) settled water obtained post coagulation, flocculation, and settling. Typical pilot influent water quality during the study is shown in Table 4-1.

Table 4-1: Pilot influent (settled) water quality

\begin{tabular}{|l|c|c|c|}
\hline Parameter & September & October & November \\
\hline $\mathrm{pH}$ & $7.3-7.4$ & $7.2-7.3$ & $7.2-7.3$ \\
\hline Temperature $\left({ }^{\circ} \mathrm{C}\right)$ & $20-24$ & $16-17$ & $9-10$ \\
\hline Turbidity $(\mathrm{NTU})$ & $0.165-0.185$ & $0.127-0.143$ & $0.118-0.138$ \\
\hline DOC $(\mathrm{mg} / \mathrm{L})$ & $3.2-3.4$ & $3.1-3.3$ & $3.2-3.3$ \\
\hline $\mathrm{UV}_{254}\left(\mathrm{~cm}^{-1}\right)$ & $0.056-0.058$ & $0.052-0.054$ & $0.051-0.053$ \\
\hline Alkalinity $\left(\mathrm{mg} / \mathrm{L}\right.$ as $\left.\mathrm{CaCO}_{3}\right)$ & $60-62$ & $59-60$ & $57-60$ \\
\hline Geosmin $(\mathrm{ng} / \mathrm{L})$ & $15-23$ & $17-21$ & $11-16$ \\
\hline MIB $(\mathrm{ng} / \mathrm{L})$ & $18-20$ & $11-15$ & BDL \\
\hline THM FP $(\mu \mathrm{g} / \mathrm{L})$ & 73.4 & 68.7 & 85.5 \\
\hline HAA FP $(\mu \mathrm{g} / \mathrm{L})$ & 74.6 & 103.8 & 108.2 \\
\hline
\end{tabular}

$\mathrm{BDL}=$ Below Detection Limit $($ Geosmin $=5.7 \mathrm{ng} / \mathrm{L} ; \mathrm{MIB}=7.1 \mathrm{ng} / \mathrm{L})$

\subsubsection{Pilot Plant Design and Operation}

Six filter columns were operated in parallel at an EBCT of $10 \mathrm{~min}$ to mimic full-scale conditions Table 4-2. Three filters contained $50 \mathrm{~cm}$ of sand (effective size $\left(\mathrm{d}_{10}\right)=0.5$, uniformity coefficient $(\mathrm{UC})=1.8$ ) and $50 \mathrm{~cm}$ of biological exhausted GAC (Filtrasorb® 300 Calgon Carbon; Pittsburgh, PA) which had been in operation for 12 years and was assumed to be exhausted in terms of adsorptive capacity. The remaining three filters contained $50 \mathrm{~cm}$ of sand $\left(\mathrm{d}_{10}=0.5, \mathrm{UC}=\right.$ $1.8)$ and $50 \mathrm{~cm}$ of anthracite $\left(\mathrm{d}_{10}=0.85, \mathrm{UC}=1.8\right)$, which was obtained from the full-scale PWTP. All filters were operated at constant head and declining flow rate. In order to maintain conditions conducive to biological filtration, five of the filters were backwashed with their individual (unchlorinated) effluent, while the conventional filter was backwashed with chlorinated water (chlorine residual $=1.5 \mathrm{mg} / \mathrm{L}$ ) from the FSP. All filters were backwashed three times a week, 
allowing for $50 \%$ filter bed expansion for 8 minutes followed by 4 minutes of slow backwash (20\% fluidization) to maintain proper media layer separation (Azzeh et al., 2015).

Table 4-2: Pilot plant configuration depicting operating conditions for each experimental phase

\begin{tabular}{|l|l|l|l|l|l|l|}
\hline & & & & & \\
& &
\end{tabular}

$\mathrm{CAF}=$ conventional anthracite filter; $\mathrm{BAF}=$ biologically active anthracite filter; $\mathrm{BAC}=$ biologically active carbon; $\mathrm{AOP}=$ advanced oxidation process

\subsubsection{Analytical Methods}

Geosmin and MIB samples were extracted using a solid phase micro-extraction (SPME) fiber and analyzed using Gas Chromatography (Varian 3800) with Mass Spectroscopy (Varian 
400) operated in electron ionization (EI) mode according to Standard Method 6040D (APHA, 2012). Complete details are presented in Section 3.2.3.

DOC was measured using a persulfate wet oxidation method as described in Section 3.2.2. A CE 3055 Single Beam Cecil UV/Visible Spectrophotometer (Cambridge, England) with $1 \mathrm{~cm}$ quartz crystal cuvette (Hewlett Packard, Mississauga) was used for measuring ultraviolet absorbance at $254 \mathrm{~nm}\left(\mathrm{UV}_{254}\right)$ and details are presented in Section 3.2.4. Organics were characterized using liquid chromatography - organic carbon detection (LC-OCD), allowing classification into five fractions including: biopolymers (proteins and polysaccharides), humic substances, building blocks, low molecular weight (LMW) acids, and LMW neutrals. LC-OCD analyses were conducted at the University of Waterloo (Waterloo, ON) according to a method described by Huber et al. (2011) and presented in Section 3.2.5.

Uniform formation condition (UFC) test was employed for DBP analysis, where samples were chlorinated in duplicate to achieve a free chlorine target residual of $1.5 \pm 0.5 \mathrm{mg} / \mathrm{L}$ following $24 \pm 2$ hours at $20^{\circ} \mathrm{C}$; without $\mathrm{pH}$ correction (APHA, 2012). Free chlorine residuals were measured as per Standard Methods 4500-Cl G (APHA, 2012), quenched using L-ascorbic acid. Liquid-liquid extraction and gas chromatography were used to analyze four THMs (chloroform, bromodichloromethane, dibromochloromethane, and bromoform) and nine HAAs (monochloroacetic acid, monobromoacetic acid, dichloroacetic acid, trichloroacetic acid, bromochloroacetic acid, dibromoacetic acid, bromodichloroacetic acid, dibromochloroacetic acid, and tribromoacetic acid) as per Standard Method 6232 B and 6251, respectively (APHA, 2012). Complete details pertaining to quantification of THMs and HAAs can be found in Section 3.2.7 and Section 3.2.8, respectively.

ATP was measured to quantify the bacterial biomass on the filter media surface $(5-10 \mathrm{~cm})$ using a LuminUltra Deposit Surface Analysis Kit (DSA-100C, Fredricton, NB) as per the manufacturer's instructions and is presented in Section 3.2.1.

\subsubsection{Statistical Methods}

All comparisons between treatments were conducted using a paired Student t-test (95\% significance level). A two-tailed test was used where the objective was to identify whether a 
difference existed between two treatments (e.g. comparison of two control biofilters), while a single-tailed test was used to determine whether a particular treatment performed better than the other treatment strategy (e.g. comparison of two pre-oxidation strategies $\mathrm{O}_{3}$ and $\mathrm{H}_{2} \mathrm{O}_{2} / \mathrm{O}_{3}$ ) as described by McKie et al. (2015). Reported p-values indicate the level at which difference between two treatments were statistically significant.

\subsection{Results and Discussion}

\subsubsection{Geosmin and MIB Removal by Conventional and Biological Filtration}

Geosmin and MIB were spiked at a target concentration of $100 \mathrm{ng} / \mathrm{L}$ immediately prior to the pilot filters. Removals across the conventional anthracite filter (CAF), biological anthracite filter (BAF), and biologically active carbon filter (BAC) are shown in Table 4-3. BAC removed $84 \%$ geosmin and $80 \% \mathrm{MIB}$, whereas BAF removed $82 \%$ geosmin and $65 \% \mathrm{MIB}$, while the CAF removed $20 \%$ geosmin and $8 \%$ MIB. This comparison between conventional and biological anthracite filters provides a good indication that biological degradation was responsible for geosmin and MIB removals.

During the study, geosmin and MIB were present in the full-scale plant (FSP) which allowed us to measure their removals across the conventional anthracite filter. It was found that 21 ng/L geosmin and $20 \mathrm{ng} / \mathrm{L}$ MIB were present in the FSP filter influent and the FSP CAF removed $28 \%$ geosmin and 17\% MIB. It should be noted that FSP CAF effluent concentrations were above odour threshold concentration (OTC $=10 \mathrm{ng} / \mathrm{L}$ ) (Olsen et al., 2016), underscoring the need for an additional treatment barrier to mitigate taste and odour events. Overall, these removals at the FSP are in agreement with published values, where less than $20 \%$ geosmin and MIB removals have been reported with conventional treatment (Newcombe et al., 2010; Srinivasan and Sorial, 2011). Consistent with the literature, geosmin was observed to be more readily degraded than MIB (Elhadi et al., 2006; Ho et al., 2007, 2002). Some authors have suggested that the planar structure of geosmin allows for easier biotransformation (Ho et al., 2002; Persson et al., 2006). Since these compounds were not removed below the $10 \mathrm{ng} / \mathrm{L}$ by biofiltration alone, pre-oxidation strategies were applied to enhance overall removals. 
Table 4-3: Geosmin and MIB removals (\%) across conventional and biological filters with anthracite and granular activated carbon media for pilot- and full-scale filters

\begin{tabular}{|l|c|c|c|c|c|c|}
\hline & \multicolumn{3}{|c|}{ Geosmin (ng/L) } & \multicolumn{3}{c|}{ MIB (ng/L) } \\
\hline Filters & Influent & Effluent & Removal (\%) & Influent & Effluent & Removal (\%) \\
\hline CAF & $85 \pm 7.3$ & $68 \pm 5.5$ & $20 \pm 1.4$ & $98 \pm 1.1$ & $90 \pm 7$ & $8 \pm 1.1$ \\
\hline BAF & $95 \pm 2.8$ & $17 \pm 6.5$ & $82 \pm 1.3$ & $100 \pm 1.6$ & $36 \pm 8.3$ & $65 \pm 1.2$ \\
\hline BAC & $92 \pm 5.7$ & $15 \pm 6.3$ & $84 \pm 1.4$ & $93 \pm 8.1$ & $18 \pm 1.2$ & $80 \pm 1.2$ \\
\hline $\begin{array}{l}\text { FSP } \\
\text { CAF }\end{array}$ & $21 \pm 3.2$ & $15 \pm 0.2$ & $28 \pm 1.1$ & $20 \pm 3.7$ & $17 \pm 1.8$ & $17 \pm 1.3$ \\
\hline
\end{tabular}

$\pm \mathrm{SD}=$ one standard deviation; $\mathrm{n}=3 ; \mathrm{CAF}=$ conventional anthracite filter; $\mathrm{BAF}=$ biologically active anthracite filter; BAC = biologically active carbon; FSP = Full-scale Plant

\subsubsection{Impact of Pre-Oxidation and Temperature on Geosmin and MIB Removal}

$\mathrm{O}_{3}$ was applied at a constant dose of $2 \mathrm{mg} / \mathrm{L}\left(0.5 \mathrm{mg} / \mathrm{L} \mathrm{O}_{3}\right.$ residual $)$ and at two water temperatures $\left(16^{\circ} \mathrm{C}\right.$ and $\left.10^{\circ} \mathrm{C}\right) . \mathrm{O}_{3}$ efficiency was observed to change as a function of temperature, resulting in a significant decrease $(\mathrm{p}<0.05)$ in geosmin and MIB removal (Table 4-4). Geosmin and MIB removals decreased from $70 \%$ to $45 \%$ and $55 \%$ to $40 \%$, at $16^{\circ} \mathrm{C}$ and $10^{\circ} \mathrm{C}$, respectively (Figure 4-1). The decrease in geosmin (25\%) and MIB (15\%) removal at $10^{\circ} \mathrm{C}$ was attributed to temperature, since the source water quality did not change with respect to DOC (3.1-3.3 mg/L) or $\mathrm{UV}_{254}\left(0.051-0.058 \mathrm{~cm}^{-1}\right)$. A bench-scale study by Elovitz et al. (2000) also showed a strong dependence between $\mathrm{O}_{3}$ reaction rates and temperature. The authors reported an $87 \%$ decrease in the first-order ozone decay rate from $4.4 \times 10^{-3} \mathrm{~s}^{-1}$ to $6 \times 10^{-4} \mathrm{~s}^{-1}$ for a temperature decrease from $25^{\circ} \mathrm{C}$ to $5^{\circ} \mathrm{C}$. In contrast, the authors reported a negligible effect when considering $\cdot \mathrm{OH}$ exposure, highlighting the benefit of $\cdot \mathrm{OH}$ oxidation in seasonally impacted waters. As $\cdot \mathrm{OH}$ concentration cannot be measured directly, the reduction rate of an $\mathrm{O}_{3}$-resistant probe compound (para-chlorobenzoic acid, pCBA) was used to calculate the $\mathrm{R}_{\mathrm{CT}}$ (Acero and von Gunten, 2001; Elovitz et al., 2000) and understand geosmin and MIB kinetics with respect to temperature.

$$
R_{C T}=\frac{\int \cdot O H d t}{\int O_{3} d t} \approx \frac{[\cdot O H]}{\left[O_{3}\right]}
$$

where $\mathrm{R}_{\mathrm{CT}}$ is defined as $\cdot \mathrm{OH}$ to $\mathrm{O}_{3}$ exposure ratios 
Table 4-4: Statistical comparison between treatment processes using paired T-tests $(\mathrm{p}<0.05)$

\begin{tabular}{|c|c|c|c|c|c|c|}
\hline \multicolumn{7}{|c|}{ MIB Removal } \\
\hline & $\mathrm{T}=16^{\circ} \mathrm{C}$ & $\mathrm{T}=10^{\circ} \mathrm{C}$ & $\mathrm{T}=16^{\circ} \mathrm{C}$ & & $\mathrm{T}=10^{\circ} \mathrm{C}$ & \\
\hline Treatments & $\mathrm{O}_{3}$ & $\mathrm{O}_{3}$ & $0.1 \mathrm{H}_{2} \mathrm{O}_{2} / \mathrm{O}_{3}$ & $0.2 \mathrm{H}_{2} \mathrm{O}_{2} / \mathrm{O}_{3}$ & $0.35 \mathrm{H}_{2} \mathrm{O}_{2} / \mathrm{O}_{3}$ & $0.5 \mathrm{H}_{2} \mathrm{O}_{2} / \mathrm{O}_{3}$ \\
\hline $\mathrm{O}_{3}{ }^{\mathrm{a}}$ & 1 & & & & & \\
\hline $\mathrm{O}_{3}$ & 0.000 & 1 & & & & \\
\hline $0.1 \mathrm{H}_{2} \mathrm{O}_{2} / \mathrm{O}_{3}{ }^{\mathrm{a}}$ & 0.000 & NA & 1 & & & \\
\hline $0.2 \mathrm{H}_{2} \mathrm{O}_{2} / \mathrm{O}_{3}$ & NA & 0.000 & 0.000 & 1 & & \\
\hline $0.35 \mathrm{H}_{2} \mathrm{O}_{2} / \mathrm{O}_{3}$ & NA & 0.000 & 0.091 & 0.001 & 1 & \\
\hline $0.5 \mathrm{H}_{2} \mathrm{O}_{2} / \mathrm{O}_{3}$ & NA & 0.000 & 0.920 & 0.000 & 0.063 & 1 \\
\hline \multicolumn{7}{|c|}{ Geosmin Removal } \\
\hline $\mathrm{O}_{3}{ }^{\mathrm{a}}$ & 1 & & & & & \\
\hline $\mathrm{O}_{3}$ & 0.000 & 1 & & & & \\
\hline $0.1 \mathrm{H}_{2} \mathrm{O}_{2} / \mathrm{O}_{3}{ }^{\mathrm{a}}$ & 0.143 & NA & 1 & & & \\
\hline $0.2 \mathrm{H}_{2} \mathrm{O}_{2} / \mathrm{O}_{3}$ & NA & 0.000 & 0.008 & 1 & & \\
\hline $0.35 \mathrm{H}_{2} \mathrm{O}_{2} / \mathrm{O}_{3}$ & NA & 0.076 & 0.037 & 0.211 & 1 & \\
\hline $0.5 \mathrm{H}_{2} \mathrm{O}_{2} / \mathrm{O}_{3}$ & NA & 0.014 & 0.124 & 0.937 & 0.136 & 1 \\
\hline
\end{tabular}

p-values representing the level of significance of the difference between two treatments $(\alpha=0.05)$

Bold indicates a significant difference between two sampling points. $\mathrm{NA}=$ Not Available. $\mathrm{T}=$ Temperature. Note temperature for all trials was $10^{\circ} \mathrm{C}$ except for two at $16^{\circ} \mathrm{C}$ as denoted by a

Westerhoff et al. (2006) quantified $\mathrm{O}_{3}$ and $\cdot \mathrm{OH}$ reaction rate kinetics for $\mathrm{MIB}$ and geosmin for a range of water qualities at bench-scale. The authors also compared the impact of temperature at a fixed $\mathrm{O}_{3}$ dose and reported $\mathrm{R}_{\mathrm{CT}}$ to decrease with a decreased temperature when considering surface waters. By lowering the temperature, geosmin and MIB oxidation rates decreased. However, $\mathrm{H}_{2} \mathrm{O}_{2}$ addition stabilizes the oxidation performance by increasing ozone decay and producing more $\cdot \mathrm{OH}$ (Elovitz et al., 2000). As such, $\mathrm{H}_{2} \mathrm{O}_{2}$ addition improved geosmin and MIB removal efficiencies in cold water condition $\left(10^{\circ} \mathrm{C}\right)$ (Figure 4-1). 


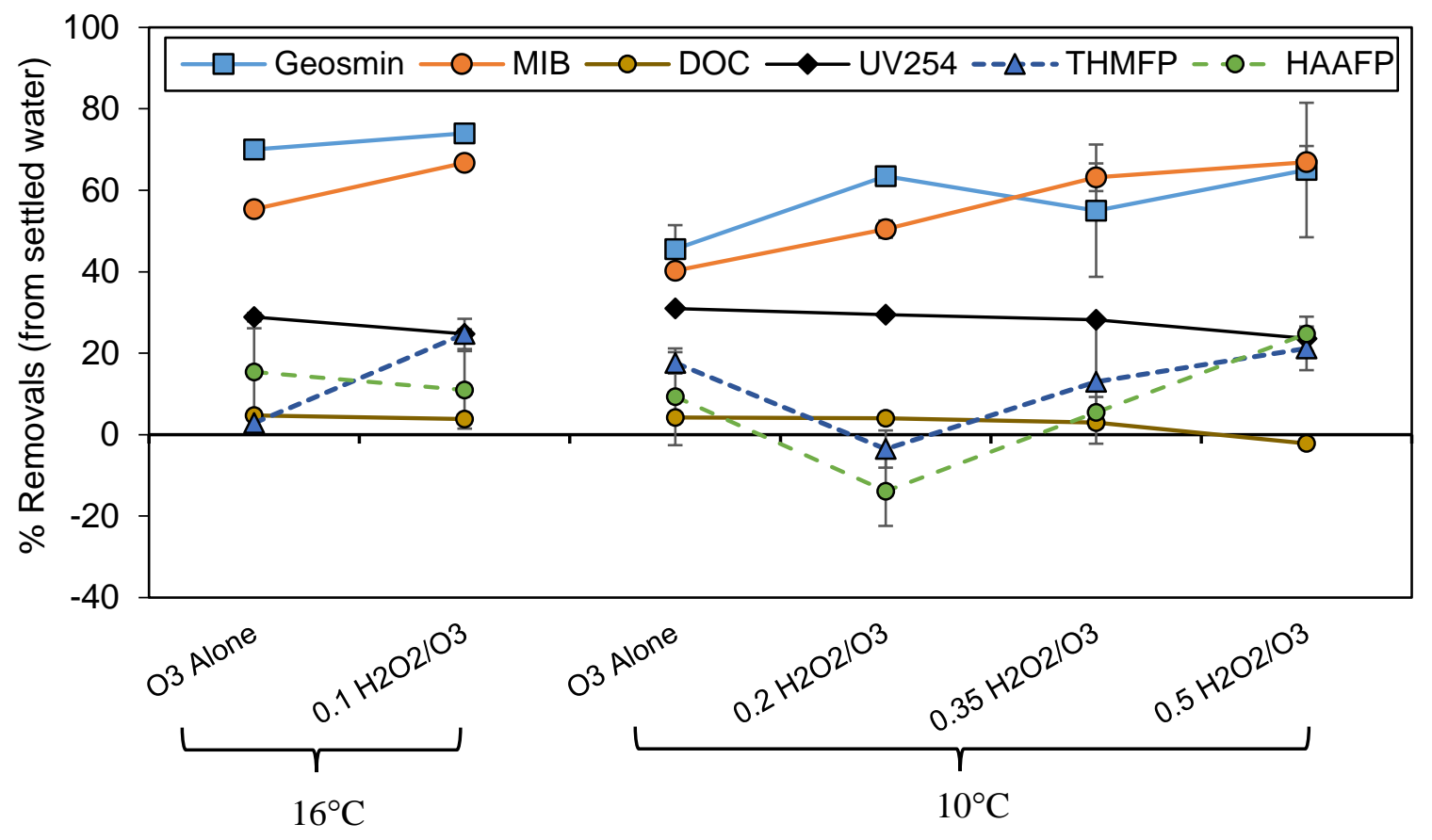

Figure 4-1: Geosmin, MIB, DOC, $\mathrm{UV}_{254}$, THMFP, and HAAFP removals (from settled water) following exposure to $2 \mathrm{mg} / \mathrm{L} \mathrm{O}_{3}$ and a range of $\mathrm{H}_{2} \mathrm{O}_{2} / \mathrm{O}_{3}$ dose $(\mathrm{mg} / \mathrm{mg})$. Vertical bars represent mean absolute deviation of experiments (geosmin, MIB, DOC, and $\mathrm{UV}_{254} \mathrm{n}=3$, THMFP and HAAFP: $\mathrm{n}=2$ )

The addition of $\mathrm{H}_{2} \mathrm{O}_{2}$ at ratios of $0.1,0.2,0.35$, and $0.5 \mathrm{mg} / \mathrm{mg} \mathrm{H}_{2} \mathrm{O}_{2} / \mathrm{O}_{3}$ statistically improved ( $\mathrm{p}<0.05$ ) MIB removals by $11 \%, 10 \%, 23 \%$, and 26\%, respectively, compared to $\mathrm{O}_{3}$ alone (Figure 4-1). These results are consistent with pilot-studies by Ferguson et al. (1990) who reported a 10-20\% improvement in geosmin and MIB removal efficiency when a $0.2 \mathrm{H}_{2} \mathrm{O}_{2} / \mathrm{O}_{3}\left(\mathrm{O}_{3}\right.$ dose $=2 \mathrm{mg} / \mathrm{L}$ ) was applied. A pilot study by Park et al. (2015) reported 7-10\% increment in MIB removal with $0.42 \mathrm{H}_{2} \mathrm{O}_{2} / \mathrm{O}_{3}$ treatment compared to $\mathrm{O}_{3}$ alone when tested at four different $\mathrm{O}_{3}$ doses $0.5,1,1.5,2 \mathrm{mg} / \mathrm{L} \mathrm{O}$ ). In the present study, addition of $0.1 \mathrm{H}_{2} \mathrm{O}_{2}$ and $0.35 \mathrm{H}_{2} \mathrm{O}_{2}$ improved MIB removal by $11 \%$ and $23 \%$, respectively, compared to $\mathrm{O}_{3}$. However, 0.35 and $0.5 \mathrm{H}_{2} \mathrm{O}_{2} / \mathrm{O}_{3}(\mathrm{mg} / \mathrm{mg})$ were not statistically different $(\mathrm{p}=0.063)$ in terms of MIB $(\sim 3 \%)$ removal; $0.35 \mathrm{H}_{2} \mathrm{O}_{2} / \mathrm{O}_{3}$ was identified as an optimal ratio for MIB reduction. Similar results were also observed by others in a bench-scale $\mathrm{H}_{2} \mathrm{O}_{2} / \mathrm{O}_{3}$ study, where an optimal ratio between 0.19 and $0.34 \mathrm{mg} / \mathrm{mg}$ for the $\cdot \mathrm{OH}$ model compound, pCBA, was identified (Acero and von Gunten, 2001). 
Consistent with the above results, MIB is more susceptible to $\cdot \mathrm{OH}$ oxidation than $\mathrm{O}_{3}$. During warmer water temperatures $\left(\mathrm{T}>16^{\circ} \mathrm{C}\right)$; effective MIB removals can be achieved with 1.5$2 \mathrm{mg} / \mathrm{L} \mathrm{O} 3$ and low $\mathrm{H}_{2} \mathrm{O}_{2} / \mathrm{O}_{3}$ ratios (0.1-0.3 mg/mg). During colder conditions $\left(10^{\circ} \mathrm{C}\right)$, effective MIB reduction requires higher $\mathrm{H}_{2} \mathrm{O}_{2} / \mathrm{O}_{3}$ ratios $(0.2-0.5 \mathrm{mg} / \mathrm{mg})$.

Addition of $\mathrm{H}_{2} \mathrm{O}_{2}$ to $\mathrm{O}_{3}$ also improved geosmin removals by $18 \%, 10 \%$, and $21 \%$, but did not result in statistically different $\left(\mathrm{p}>0.05\right.$ ) reductions at $0.2,0.35$, and $0.5 \mathrm{H}_{2} \mathrm{O}_{2} / \mathrm{O}_{3}$ ratios, respectively, indicating that at $10^{\circ} \mathrm{C}$, an optimal ratio of $0.2 \mathrm{H}_{2} \mathrm{O}_{2} / \mathrm{O}_{3}$ can provide the most effective geosmin removal (64\%). Park et al. (2015) reported an average 10-20\% improvement in geosmin removal when $\mathrm{O}_{3}$ dose was varied from 0.5 to $2 \mathrm{mg} / \mathrm{L}$ at a fixed $0.42 \mathrm{H}_{2} \mathrm{O}_{2} / \mathrm{O}_{3}$ ratio. Wang et al. (2015) reported $91 \%$ and $94 \%$ geosmin removals at 0.2 and $0.4 \mathrm{H}_{2} \mathrm{O}_{2} / \mathrm{O}_{3}$ ratios $\left(\mathrm{O}_{3}\right.$ dose $\left.=2 \mathrm{mg} / \mathrm{L}\right)$, identifying $0.2 \mathrm{H}_{2} \mathrm{O}_{2} / \mathrm{O}_{3}$ as an optimal ratio for geosmin removal. Therefore, at warmer temperatures $\left(\mathrm{T}=16^{\circ} \mathrm{C}\right)$, effective geosmin removals can be achieved for $1.5-2 \mathrm{mg} / \mathrm{L} \mathrm{O}_{3}$, however in colder water temperatures $\left(10^{\circ} \mathrm{C}\right)$, addition of $0.1-0.2 \mathrm{H}_{2} \mathrm{O}_{2} / \mathrm{O}_{3}$ is required to match the results of $\mathrm{O}_{3}$ alone at $16^{\circ} \mathrm{C}$.

\subsubsection{Impact of Pre-Oxidation and Temperature on MIB and Geosmin Biodegradation}

Similar to pre-oxidation, temperature significantly impacted $(\mathrm{p}<0.05)$ MIB and geosmin removals across BAC (Table 4-5). For example, the BAC control (no pre-oxidation) removed 85\%, $60 \%$, and $46 \% \mathrm{MIB}$ at $22^{\circ} \mathrm{C}, 16^{\circ} \mathrm{C}$, and $10^{\circ} \mathrm{C}$, respectively (Figure 4-2 and Figure 4-3, respectively). A decrease in BAC ATP was also observed between $22^{\circ} \mathrm{C}$ and $10^{\circ} \mathrm{C}$ from $530 \mathrm{ng}$ ATP/g BAC to $151 \mathrm{ng}$ ATP/g BAC. As such, the decrease in MIB and geosmin removals across BAC may be due to lowered bacterial biomass (Moll et al., 1999). Bench-scale studies by Elhadi et al. (2004) reported a 40\% decrease in geosmin and MIB removals ( $<$ < 0.05) across exhausted $\mathrm{GAC} /$ sand filters operated at water temperatures of $20^{\circ} \mathrm{C}$ vs $8^{\circ} \mathrm{C}$. In the present study, at $22^{\circ} \mathrm{C}$, BAC alone may serve as a suitable treatment technology for MIB and geosmin treatment however for lower temperatures, an additional treatment process would be required to achieve reductions to < $10 \mathrm{ng} / \mathrm{L}$. Application of $\mathrm{O}_{3}(2 \mathrm{mg} / \mathrm{L})$ prior to BAC improved overall MIB removal by $20 \%$ and $15 \%$ at $16^{\circ} \mathrm{C}$ and $10^{\circ} \mathrm{C}$, respectively. 
Table 4-5: Statistical Comparison of Treatment Processes Using Paired T-Tests

\begin{tabular}{|c|c|c|c|c|c|c|c|c|}
\hline \multicolumn{2}{|c|}{ Treatments compared } & $\begin{array}{l}\text { Geosmin } \\
\text { Removal }\end{array}$ & $\begin{array}{c}\text { MIB } \\
\text { Removal }\end{array}$ & SUVA & $\mathbf{U} \mathbf{V}_{254}$ & DOC & THMFP & HAAFP \\
\hline Control BAC & CAF & 0.001 & 0.000 & 0.629 & $\mathbf{0 . 0 0 7}$ & 0.000 & 0.865 & 0.074 \\
\hline Control BAC & BAF & 0.525 & 0.004 & 0.987 & 0.094 & 0.019 & 0.237 & 0.173 \\
\hline Control BAC & $\mathrm{BAC}$ & 0.674 & 0.066 & 0.615 & 0.158 & 0.108 & 0.194 & 0.260 \\
\hline Control BAC & $2 \mathrm{mg} / \mathrm{L} \mathrm{O}_{3}-\mathrm{BAF} @ 16^{\circ} \mathrm{C}$ & 0.001 & 0.006 & 0.001 & 0.001 & 0.007 & 0.015 & 0.448 \\
\hline Control BAC & $2 \mathrm{mg} / \mathrm{L} \mathrm{O}_{3}-\mathrm{BAF} @ 10^{\circ} \mathrm{C}$ & 0.103 & 0.002 & 0.000 & 0.000 & 0.096 & 0.030 & 0.614 \\
\hline Control BAC & $2 \mathrm{mg} / \mathrm{L} \mathrm{O}_{3}-\mathrm{BAC} @ 16^{\circ} \mathrm{C}$ & 0.001 & 0.001 & 0.001 & 0.000 & 0.006 & 0.590 & 0.022 \\
\hline Control BAC & $2 \mathrm{mg} / \mathrm{L} \mathrm{O}_{3}-\mathrm{BAC} @ 10^{\circ} \mathrm{C}$ & 0.011 & 0.000 & 0.000 & 0.000 & 0.101 & 0.046 & 0.202 \\
\hline Control BAC & $0.1 \mathrm{H}_{2} \mathrm{O}_{2} / \mathrm{O}_{3}-\mathrm{BAC}$ & 0.000 & 0.001 & 0.002 & 0.001 & 0.001 & 0.011 & 0.229 \\
\hline Control BAC & $0.2 \mathrm{H}_{2} \mathrm{O}_{2} / \mathrm{O}_{3}-\mathrm{BAC}$ & 0.001 & 0.000 & 0.000 & 0.000 & 0.263 & 0.101 & 0.559 \\
\hline Control BAC & $0.35 \mathrm{H}_{2} \mathrm{O}_{2} / \mathrm{O}_{3}-\mathrm{BAC}$ & 0.027 & 0.143 & 0.228 & 0.006 & 0.022 & 0.214 & 0.501 \\
\hline Control BAC & $0.5 \mathrm{H}_{2} \mathrm{O}_{2} / \mathrm{O}_{3}-\mathrm{BAC}$ & 0.061 & 0.039 & 0.211 & 0.006 & 0.019 & 0.778 & 0.349 \\
\hline $0.1 \mathrm{H}_{2} \mathrm{O}_{2} / \mathrm{O}_{3}-\mathrm{BAC}$ & $0.2 \mathrm{H}_{2} \mathrm{O}_{2} / \mathrm{O}_{3}-\mathrm{BAC}$ & 0.047 & 0.001 & 0.273 & 0.266 & 0.821 & 0.061 & 0.010 \\
\hline $0.1 \mathrm{H}_{2} \mathrm{O}_{2} / \mathrm{O}_{3}-\mathrm{BAC}$ & $0.35 \mathrm{H}_{2} \mathrm{O}_{2} / \mathrm{O}_{3}-\mathrm{BAC}$ & 0.000 & $\mathbf{0 . 0 0 3}$ & 0.727 & 0.321 & 0.125 & 0.015 & 0.005 \\
\hline $0.1 \mathrm{H}_{2} \mathrm{O}_{2} / \mathrm{O}_{3}-\mathrm{BAC}$ & $0.5 \mathrm{H}_{2} \mathrm{O}_{2} / \mathrm{O}_{3}-\mathrm{BAC}$ & 0.005 & 0.019 & 0.609 & 0.257 & 0.080 & 0.008 & 0.311 \\
\hline $0.2 \mathrm{H}_{2} \mathrm{O}_{2} / \mathrm{O}_{3}-\mathrm{BAC}$ & $0.35 \mathrm{H}_{2} \mathrm{O}_{2} / \mathrm{O}_{3}-\mathrm{BAC}$ & 0.000 & 0.198 & 0.352 & 0.028 & 0.137 & 0.913 & 0.037 \\
\hline $0.2 \mathrm{H}_{2} \mathrm{O}_{2} / \mathrm{O}_{3}-\mathrm{BAC}$ & $0.5 \mathrm{H}_{2} \mathrm{O}_{2} / \mathrm{O}_{3}-\mathrm{BAC}$ & 0.001 & 0.079 & 0.275 & 0.026 & 0.084 & 0.097 & 0.034 \\
\hline $0.35 \mathrm{H}_{2} \mathrm{O}_{2} / \mathrm{O}_{3}-\mathrm{BAC}$ & $0.5 \mathrm{H}_{2} \mathrm{O}_{2} / \mathrm{O}_{3}-\mathrm{BAC}$ & 0.274 & 0.002 & 0.927 & 0.824 & 0.438 & 0.056 & 0.123 \\
\hline
\end{tabular}

p-values representing the level of significance of the difference between two treatments $(\alpha=0.05)$

Bold indicates a significant difference between two sampling points 


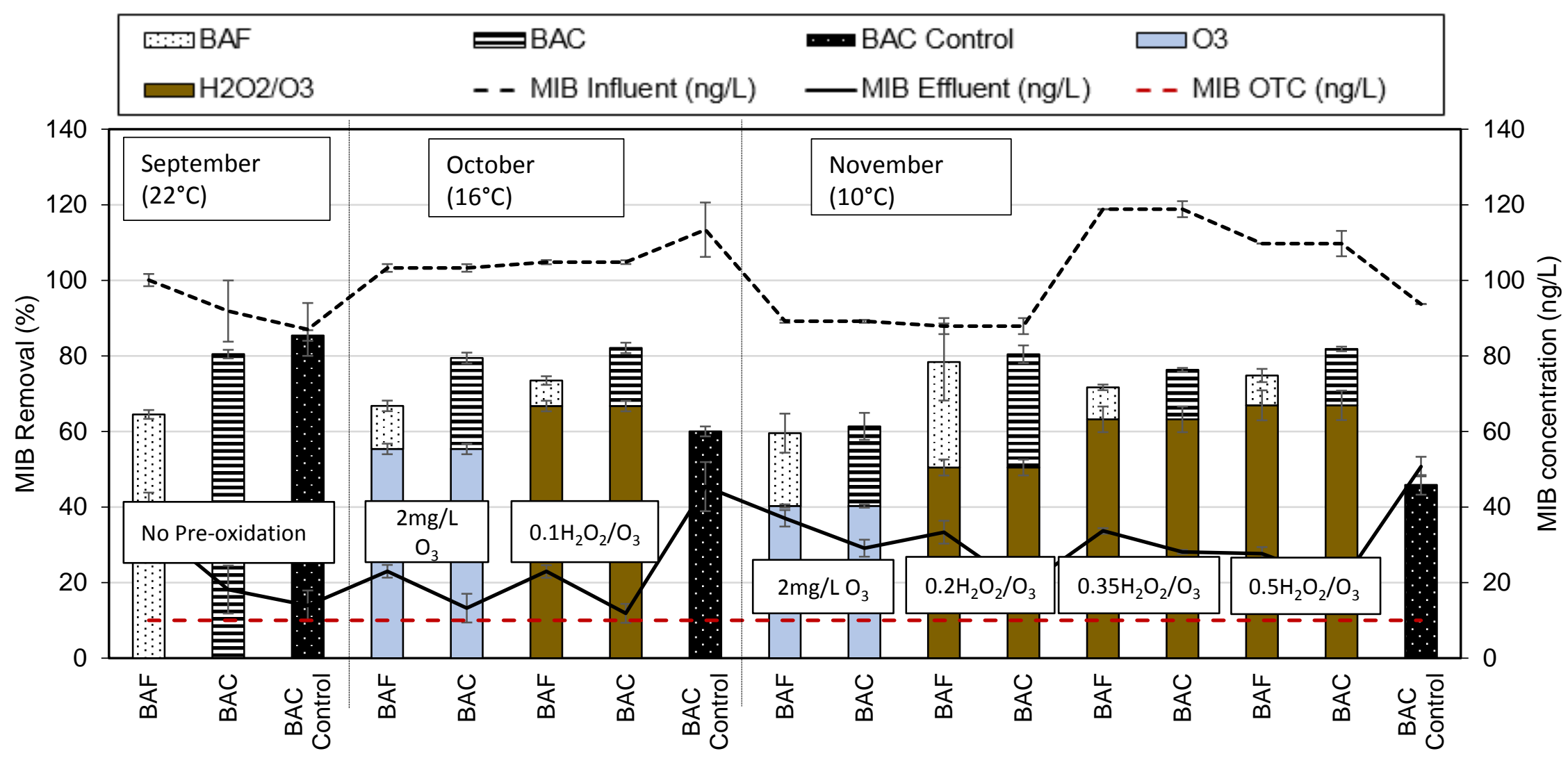

Figure 4-2: $\mathrm{MIB}$ removal as a result of: no pre-oxidation, ozonation, $\mathrm{H}_{2} \mathrm{O}_{2} / \mathrm{O}_{3}$ alone and in combination with subsequent biofiltration. Transferred ozone dose $=2 \pm 0.1 \mathrm{mg} / \mathrm{L}$; ozone contact time $=12 \mathrm{~min}$; EBCT $=10 \mathrm{~min}$. Vertical bars represent one standard deviation ( $\mathrm{n}=3$ for each experiment). OTC $=$ Odour threshold concentration $(10 \mathrm{ng} / \mathrm{L})$. 


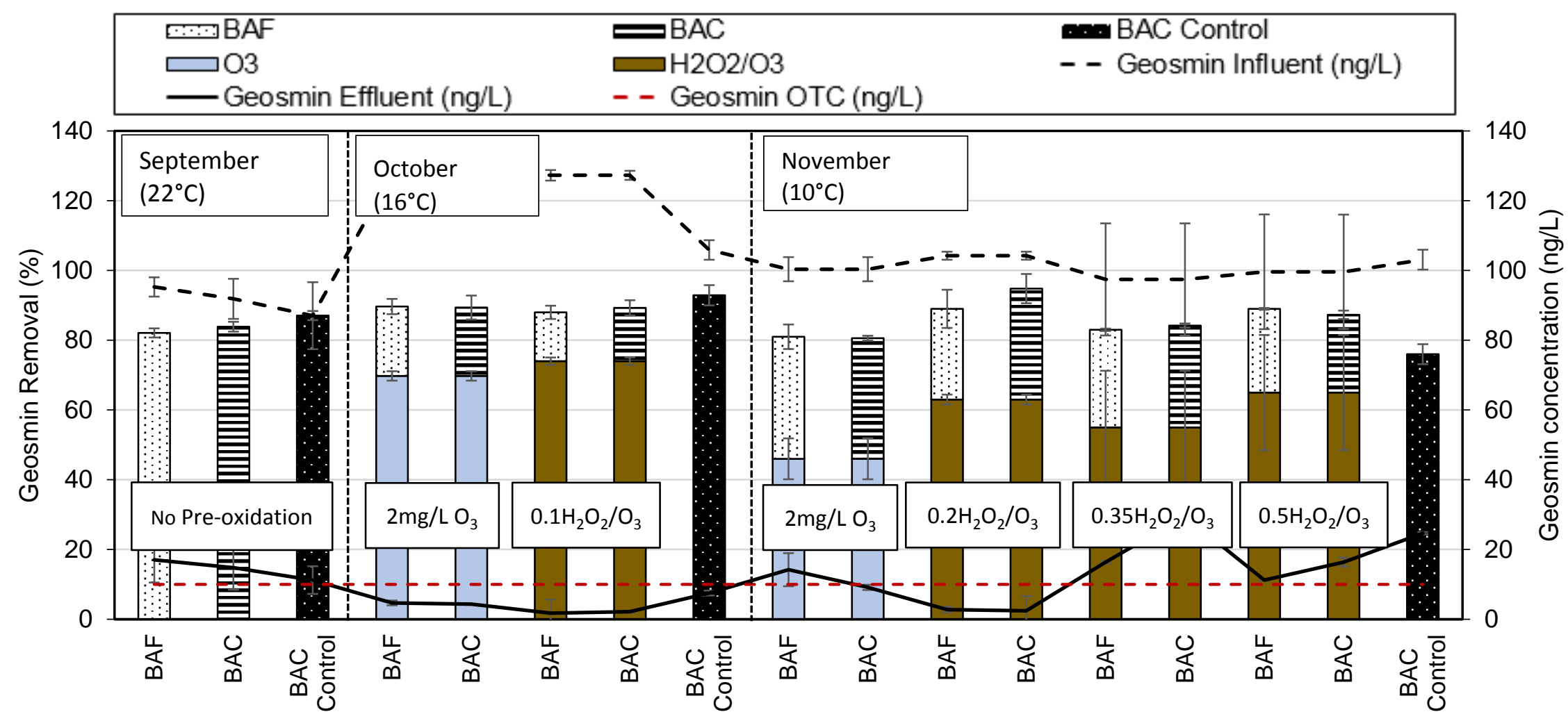

Figure 4-3: Geosmin removal as a result of: no pre-oxidation, ozonation, $\mathrm{H}_{2} \mathrm{O}_{2} / \mathrm{O}_{3}$ alone and in combination with subsequent biofiltration. Transferred ozone dose $=2 \pm 0.1 \mathrm{mg} / \mathrm{L}$; ozone contact time $=12 \mathrm{~min} ; \mathrm{EBCT}=10 \mathrm{~min}$. Vertical bars represent one standard deviation $(\mathrm{n}=3$ for each experiment). OTC $=$ Odour threshold concentration $(10 \mathrm{ng} / \mathrm{L})$. 


\subsubsection{Impact of Pre-Oxidation Organics Removal}

\section{Pre-Oxidation and Biofiltration Impacts on DOC and $U V_{254}$ Reduction}

$\mathrm{O}_{3}(2 \mathrm{mg} / \mathrm{L})$ and three $\mathrm{H}_{2} \mathrm{O}_{2} / \mathrm{O}_{3}$ ratios $(0.1,0.2,0.35)$ had little impact $(\mathrm{p}>0.05)$ on DOC removal $(4 \pm 1 \%)$, however $\mathrm{UV}_{254}$ absorbance significantly reduced by $28 \pm 3 \%$ (Figure 4-4), indicating transformation of aromatic organic compounds to low molecular weight aliphatic products (Lautenschlager et al., 2014; Ramseier and von Gunten, 2009).

Pre-oxidation with $\mathrm{O}_{3}$ and $\mathrm{H}_{2} \mathrm{O}_{2} / \mathrm{O}_{3}$ improved biofiltration performance in terms of DOC reduction (Figure 4-4). BAC preceded with $\mathrm{O}_{3}(2 \mathrm{mg} / \mathrm{L})$ and $0.1 \mathrm{H}_{2} \mathrm{O}_{2} / \mathrm{O}_{3}$ reduced DOC by $11 \%$ and $12 \%$, compared to a $6 \%$ reduction across the BAC control. BAF operated with the same oxidation conditions showed $10 \%$ and $9 \%$ DOC reduction, respectively, compared to a $3 \%$ decrease for the BAF control. Increasing the $\mathrm{H}_{2} \mathrm{O}_{2} / \mathrm{O}_{3}$ ratio from 0.1 to 0.5 resulted in a small decrease in DOC (2\%-4\%) for both BAC and BAF (Figure 4-4). Temperature decreased during this period impacting biofiltration performance. DOC reduction across the BAC control decreased (1-3\%) during cold water temperatures $\left(10^{\circ} \mathrm{C}\right)$.

\section{Impact of Pre-Oxidation on NOM Characterization}

LC-OCD was used to characterize changes in NOM structure following pre-oxidation and biofiltration. Humic substances contributed on average $65 \%$ of the total DOC, followed by building blocks (15\%), LMW neutrals (12\%), and biopolymers (8\%) for this source water, which is similar to other water sources in the region (Zheng et al., 2014). Biopolymers represent the largest sized fraction (molecular weight $(\mathrm{MW})>10,000 \mathrm{~g} / \mathrm{mol}$ ) and are composed of polysaccharide- and protein-like molecules. Humic substances represent a mix of polycarboxylic acids and substituted phenols (MW = 500-1200 g/mol). Building blocks represent polycarboxylic acids (MW = 350-500 g/mol); LMW neutrals represent amino acids, aldehydes, and ketones (MW $=<350 \mathrm{~g} / \mathrm{mol}$ ) (Huber et al., 2011). 


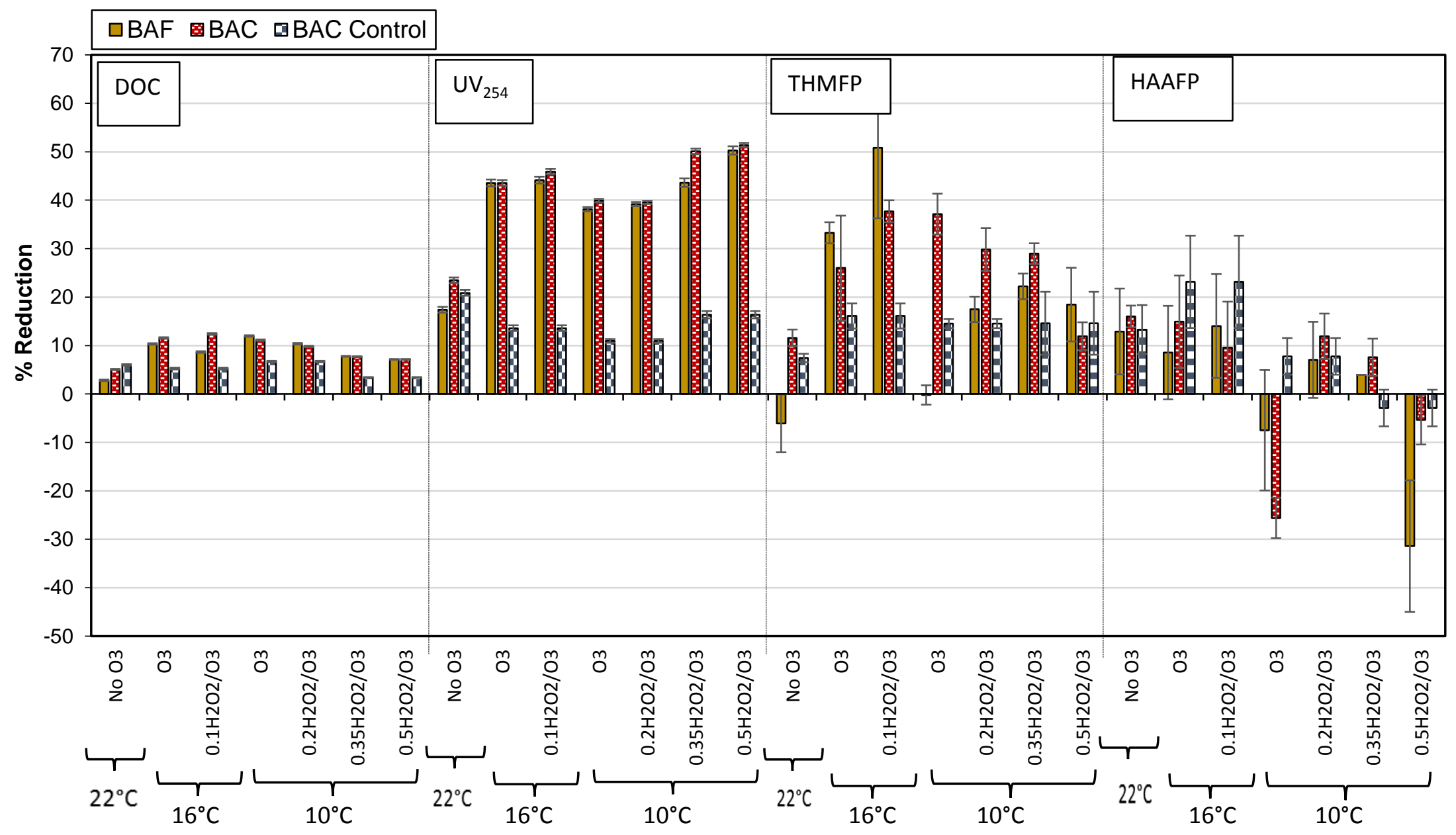

Figure 4-4: Reduction (\%) of (a) dissolved organic carbon (DOC) (b) $\mathrm{UV}_{254}$ absorbance, (c) THMFP, (d) HAAFP as a function of $\mathrm{O}_{3}$ and $\mathrm{O}_{3} / \mathrm{H}_{2} \mathrm{O}_{2}$ pre-treatment for BAF and BAC filters. Vertical bars for DOC and $\mathrm{UV}_{254}$ represent 1 standard deviation (n=3); Vertical bars for THMFP and HAAFP represent mean absolute deviation. 
Pre-oxidation with $\mathrm{O}_{3}$ and $\cdot \mathrm{OH}$ decreased biopolymers as a function of $\mathrm{H}_{2} \mathrm{O}_{2} / \mathrm{O}_{3}$ ratios (Figure 4-5). $\mathrm{H}_{2} \mathrm{O}_{2} / \mathrm{O}_{3}$ ratio was directly related $\left(\mathrm{R}^{2}=0.89\right)$ with biopolymer removal (increase from $-2 \%$ to $12 \%$ ). Biopolymers were observed to preferentially react with $\cdot \mathrm{OH}$ rather than $\mathrm{O}_{3}$. These results are consistent with those reported by other advanced oxidation studies using $\mathrm{UV} / \mathrm{H}_{2} \mathrm{O}_{2}$ (Sarathy and Mohseni, 2007; Black and Bérubé, 2014). When considering humic substances, $\mathrm{O}_{3}$ achieved a $20 \%$ reduction, likely resulting in an increase to building blocks (28\% increase) (Zietzschmann et al., 2015). No distinct trend was observed with respect to humic substances and $\mathrm{H}_{2} \mathrm{O}_{2} / \mathrm{O}_{3}$ oxidation. $\mathrm{H}_{2} \mathrm{O}_{2} / \mathrm{O}_{3}$ oxidation generally achieved higher LMW neutral reductions (range $1 \%$ to $15 \%$ ) when compared to $\mathrm{O}_{3}(6 \%)$.
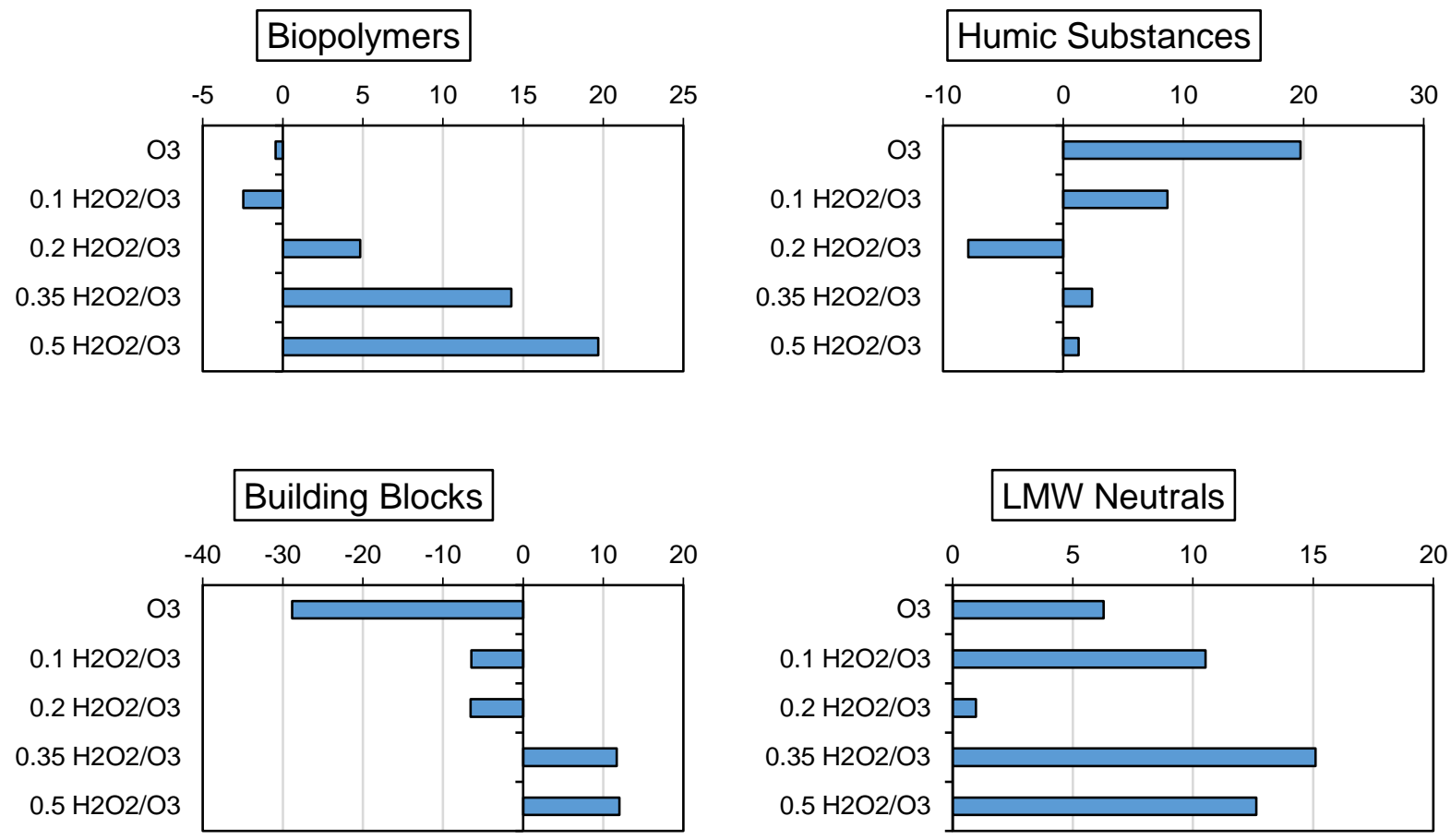

Figure 4-5: \% Reduction of LC-OCD fractions from settled water 


\subsubsection{Pre-Oxidation and Biofiltration for DBP Formation Reduction}

Statistically significant $(\mathrm{p}<0.05)$ reductions for THMFP and HAAFP from settled water were observed when considering the control BAC, with an average reduction of $13 \%$ (range $8 \%$ to $16 \%$ ) and $10 \%$ (range $-3 \%$ to $23 \%$ ), respectively (Figure 4-4). Further, the observed THM FP and HAA FP across BAC were lower than those for the conventional filter (Appendix Table 7-6), supporting the effectiveness of biodegradation for reduction of THM and HAA precursors.

Although $\mathrm{O}_{3}$ had little impact on DOC reduction (4\%), it reduced THMFP and HAAFP by an average of $10 \%$ (range $3 \%$ to $18 \%$ ) and $12 \%$ (range $9 \%$ to $15 \%$ ), respectively (Figure $4-1$ ). These reductions can be attributed to oxidation of aromatic constituents into aliphatic products (Swietlik et al., 2004), which contain fewer halogenation sites and therefore result in lower THMFP and HAAFP (Westerhoff et al., 2004). This is also reflected by a large reduction (37\%) in specific UV absorbance at $254 \mathrm{~nm}$ (SUVA) (from $1.58 \mathrm{~L} / \mathrm{mg}$-cm to $0.99 \mathrm{~L} / \mathrm{mg}$-cm) after ozonation of settled water. These results are in agreement with the DBP reductions reported by de Vera et al., (2015) and Vasyukova et al. (2013) but in contrast with those by Zha et al. (2016), where authors reported an adverse effect on DBPFP, especially on HAAFP after $\mathrm{O}_{3}(2 \mathrm{mg} / \mathrm{L})$ preoxidation. The difference in the latter's HAAFP is attributed to an increased concentration of MCAA from $14 \mu \mathrm{g} / \mathrm{L}$ to $139 \mu \mathrm{g} / \mathrm{L}$ after ozonation, which is most likely due to the generation of newer halogenation sites in relation to the formation of aldehydes, ketones, and alcohols after incomplete ozonation (Kleiser and Frimmel, 2000). A bench-scale study by Karnik et al. (2005) reported slower reaction of HAA precursors with $\mathrm{O}_{3}$ and suggested a longer contact time for improved reduction.

When considering a low $(0.1) \mathrm{H}_{2} \mathrm{O}_{2} / \mathrm{O}_{3}$ ratio, significant $(\mathrm{p}<0.05)$ THMFP reductions were observed for settled (25\%) and ozonated (22\%) water, respectively. However, an increase in $\mathrm{H}_{2} \mathrm{O}_{2} / \mathrm{O}_{3}$ ratio from 0.2 to 0.5 did not have a significant impact on THMFP reductions when compared to both the settled and ozonated waters. This could be explained by LC-OCD fraction reductions. A strong correlation between building blocks and total THMFP concentrations $\left(\mathrm{R}^{2}=\right.$ 0.86) was observed but only for chlorinated waters following $\mathrm{H}_{2} \mathrm{O}_{2} / \mathrm{O}_{3}$ treatment. As building blocks have been identified by others as potential THM precursors (Fabris et al., 2008; Vasyukova et al., 2013), an increasing building blocks $(28 \%)$ due to $\mathrm{O}_{3}$ were consistent with higher THMFP 
compared to $0.1 \mathrm{H}_{2} \mathrm{O}_{2} / \mathrm{O}_{3}$. These correlations suggest low molecular weight polycarboxylic acids (represented by building blocks) to be THM precursors. Similar association of building blocks can be inferred with THMFP and other $\mathrm{H}_{2} \mathrm{O}_{2} / \mathrm{O}_{3}$ ratios (Figure 4-5). Only a $0.5 \mathrm{H}_{2} \mathrm{O}_{2} / \mathrm{O}_{3}$ ratio observed 17\% lower HAAFP than $\mathrm{O}_{3}$ (Table S3), likely due to a reduction in biopolymers (Figure 4-5). Biopolymers were moderately correlated with $\operatorname{HAAFP}\left(\mathrm{R}^{2}=0.54\right.$ and 0.60$)$ in chlorinated waters after pre-oxidation $\left(\mathrm{O}_{3}\right.$ combined with $\mathrm{H}_{2} \mathrm{O}_{2} / \mathrm{O}_{3}$ and $\mathrm{H}_{2} \mathrm{O}_{2} / \mathrm{O}_{3}$ alone, respectively), indicating high molecular weight biopolymers to be HAA precursors. Further, we are not aware of any prior studies that have investigated the impact of four $\mathrm{H}_{2} \mathrm{O}_{2} / \mathrm{O}_{3}$ ratios on LC-OCD fractions for identifying THM and HAA precursors and therefore its impact is worth investigating in different source waters.

$\mathrm{O}_{3}$ prior to both $\mathrm{BAF}$ and $\mathrm{BAC}$ reduced THMFP (average reduction of $17 \%$ and $32 \%$, respectively) when compared with $13 \%$ for the BAC control (Figure 4-4). The slightly improved removal for BAC vs BAF can be attributed to higher biodegradation (Dussert and Tramposch, 1997). $\mathrm{H}_{2} \mathrm{O}_{2} / \mathrm{O}_{3}$ prior to $\mathrm{BAF}$ and $\mathrm{BAC}$ also improved THMFP by an average of $25 \%$ and $26 \%$, respectively. However, no statistically different $(\mathrm{p}>0.05)$ results for either BAF or BAC were observed after pre-oxidation with $\mathrm{O}_{3}$ and $\mathrm{H}_{2} \mathrm{O}_{2} / \mathrm{O}_{3}$ (Table 4-5). To some extent, these results corroborate findings by Black and Bérubé (2014), who reported no significant impact on the biodegradation rate of NOM using BAC after pre-oxidation with $\mathrm{O}_{3}$ and UV AOP.

Application of $\mathrm{O}_{3}$ and $\mathrm{H}_{2} \mathrm{O}_{2} / \mathrm{O}_{3}$ prior to both $\mathrm{BAF}$ and $\mathrm{BAC}$ resulted in no statistical difference ( $p>0.05)$ in HAAFP reductions when compared with the BAC control (Table 4-5). In addition, no discernible trend was observed in the performance of BAF, BAC, and the BAC control in reducing HAAFP at colder conditions $\left(10^{\circ} \mathrm{C}\right)$ (Figure 4-4). The relatively low reduction of HAAFPs at low temperature can be attributed to poor biodegradability of HAA precursors (Kim, 2009), likely biopolymers. Similar impact on biopolymer biodegradation across biofilters (with $\mathrm{O}_{3}$ pre-oxidation) was reported by Pharand et al., (2015) when temperature decreased below $10^{\circ} \mathrm{C}$. As such, these removals may be enhanced by increasing the biofilter EBCT (de Vera et al., 2016; Seredyńska-Sobecka et al., 2006).

Monitoring NOM fractions using LC-OCD provided deeper insight regarding organic matter behavior over a wide molecular weight range. Treatment-specific correlations were examined between various organic fractions and THMFP as well as HAAFP (Table 4-6). A strong 
correlation between building blocks and total THMFP concentrations $\left(\mathrm{R}^{2}=0.86\right)$ was observed but only for chlorinated waters following $\mathrm{H}_{2} \mathrm{O}_{2} / \mathrm{O}_{3}$ treatment. These results are in agreement with Vasyukova et al. (2013), who reported building blocks to be correlated with THMFP $\left(\mathrm{R}^{2}=0.77\right)$ in chlorinated waters of treatments including pre-ozonation. Similarly, biopolymers were moderately correlated with HAAFP $\left(\mathrm{R}^{2}=0.54\right.$ and 0.60$)$ in chlorinated waters after pre-oxidation ( $\mathrm{O}_{3}$ combined with $\mathrm{H}_{2} \mathrm{O}_{2} / \mathrm{O}_{3}$ and $\mathrm{H}_{2} \mathrm{O}_{2} / \mathrm{O}_{3}$ alone, respectively). These correlations suggest low molecular weight polycarboxylic acids (represented by building blocks) and high molecular weight biopolymers to be THM and HAA precursors. Further, we are not aware of any prior studies that have investigated the impact of four $\mathrm{H}_{2} \mathrm{O}_{2} / \mathrm{O}_{3}$ ratios on LC-OCD fractions for identifying THM and HAA precursors and therefore its impact is worth investigating in different source waters.

Table 4-6: R-squared values for linear correlations between DBP precursors and various organic fractions from LC-OCD analysis

\begin{tabular}{|l|l|c|c|c|c|}
\hline \multicolumn{2}{|l|}{} & Biopolymers & $\begin{array}{l}\text { Humic } \\
\text { substances }\end{array}$ & $\begin{array}{l}\text { Building } \\
\text { blocks }\end{array}$ & $\begin{array}{l}\text { LMW } \\
\text { neutrals }\end{array}$ \\
\hline \multirow{2}{*}{$\mathrm{H}_{2} \mathrm{O}_{2} / \mathrm{O}_{3}$ AOP $(\mathrm{n}=4)$} & THMFP & 0.25 & 0.11 & $\mathbf{0 . 8 6}$ & 0.46 \\
\cline { 2 - 6 } & HAAFP & $\mathbf{0 . 6 0}$ & 0.04 & 0.19 & 0.01 \\
\hline $\begin{array}{l}\text { Preoxidation }\left(\mathrm{O}_{3}+\right. \\
\mathrm{H}_{2} \mathrm{O}_{2} / \mathrm{O}_{3} \text { AOP) }(\mathrm{n}=6)\end{array}$ & THMFP & 0.24 & 0.10 & 0.19 & 0.31 \\
\cline { 2 - 6 } & HAAFP & $\mathbf{0 . 5 4}$ & 0.05 & 0.17 & 0.07 \\
\hline $\begin{array}{l}\text { Biofiltration (with } \\
\text { pre-oxidation) }(n=16)\end{array}$ & THMFP & 0.00 & 0.00 & 0.50 & $\mathbf{0 . 6 7}$ \\
\cline { 2 - 6 } & HAAFP & 0.09 & 0.08 & 0.21 & $\mathbf{0 . 6 6}$ \\
\hline $\begin{array}{l}\text { Pre-oxidation + } \\
\text { Biofiltration (n=22) }\end{array}$ & THMFP & 0.00 & 0.02 & 0.14 & 0.19 \\
\cline { 2 - 6 } & HAAFP & 0.08 & 0.11 & 0.33 & 0.44 \\
\hline
\end{tabular}

Bold values represent R-squared > 0.5

Correlations between LMW neutrals and THM and HAA formation potentials after biofiltration (with pre-oxidation) $\left(\mathrm{R}^{2}=0.67\right.$ and 0.66 , respectively) were observed, indicating that these fractions play a role in THM and HAA formation potentials. These results suggest that biofiltration (with pre-oxidation) metabolized LMW neutrals thus, reducing the overall THM and HAA formation potentials (Figure 4-6). 


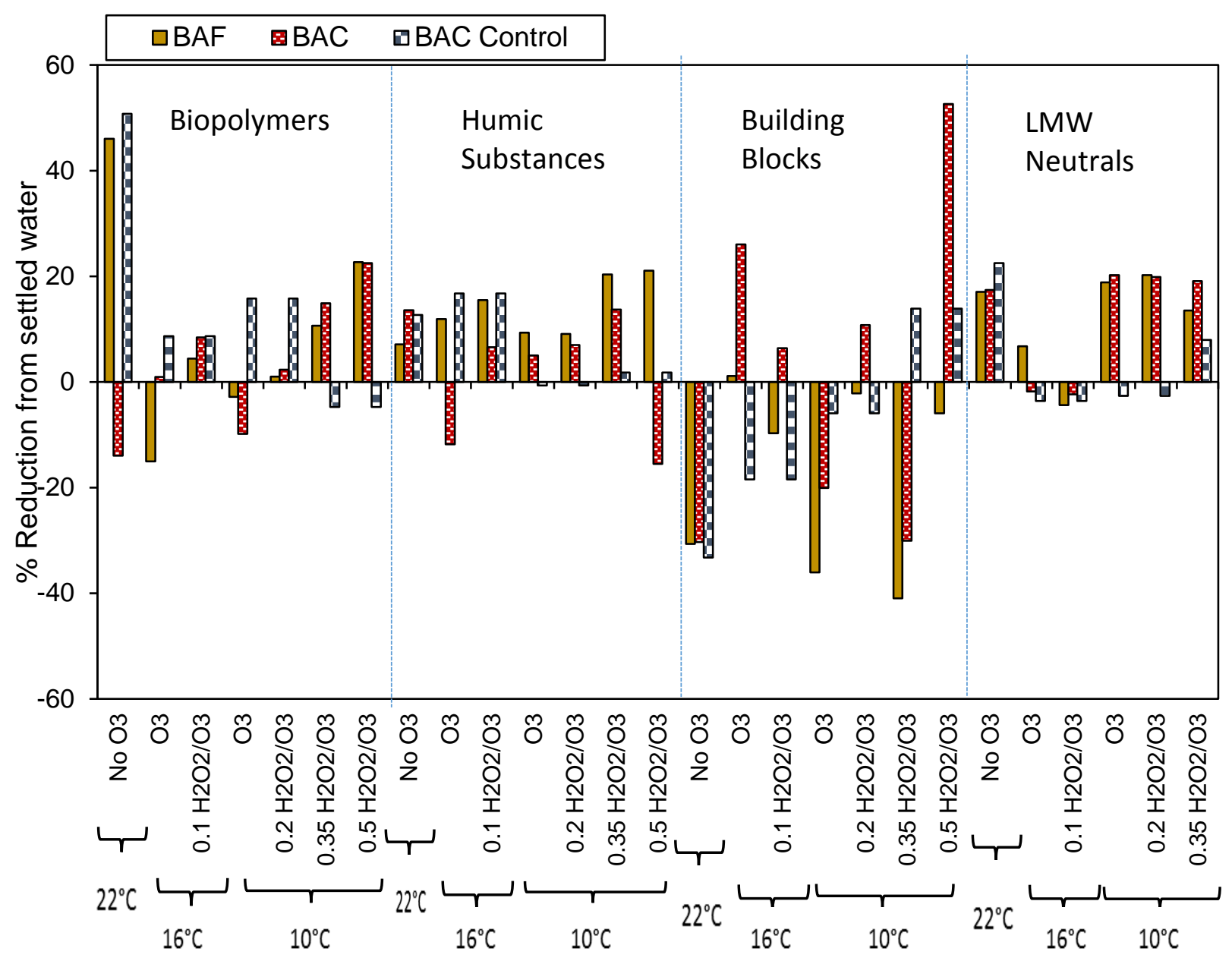

Figure 4-6: \% Reduction of LC-OCD fractions across biofiltration

\subsubsection{Filter Media ATP Analysis}

ATP levels on filter media were measured to estimate the active biomass in the top 5-10 $\mathrm{cm}$ of the filters (Velten et al., 2011). ATP values of control BAC reached its peak value in early August $(765 \mathrm{ng} / \mathrm{g}$ ) and gradually decreased during September $(530 \mathrm{ng} / \mathrm{g})$ to late November (150 $\mathrm{ng} / \mathrm{g}$ ) (Figure 4-7). The decrease in ATP is likely due to variation with respect to assimilable organics in source water that might have impacted biomass formation (Korotta-Gamage and Sathasivan, 2017). 
On supplying with ozonated water, BAC resulted in one time two-fold increase of ATP (from $240 \mathrm{ng} / \mathrm{g}$ to $475 \mathrm{ng} / \mathrm{g}$ ) (Figure 6). Further pre-oxidation using $\mathrm{O}_{3}$ and $\mathrm{H}_{2} \mathrm{O}_{2} / \mathrm{O}_{3}$ did not result in any improvement in BAC ATP, rather resulted in decreased ATP during October and November similar to those of control BAC. To some extent, these BAC ATP values followed an opposite trend when compared to the literature values, where studies have reported accelerated biomass formation after pre-ozonation (Magic-Knezev and van der Kooij, 2004; Pharand et al., 2014). This could be attributed to decelerated biomass formation in winter compared to summer (van der Wielen and van der Kooij, 2010). Additionally, there was no significant impact of pre-oxidation on BAF ATP. Further, BAF ATP values remained steady from August till November, which is likely due to formation of consistent biomass at the surface. Despite reduced ATP of BAC and control BAC, there was no significant impact on DOC reduction for the conditions tested in this study (Table S1), warranting further research with regard to role of viable biomass in degrading organics.

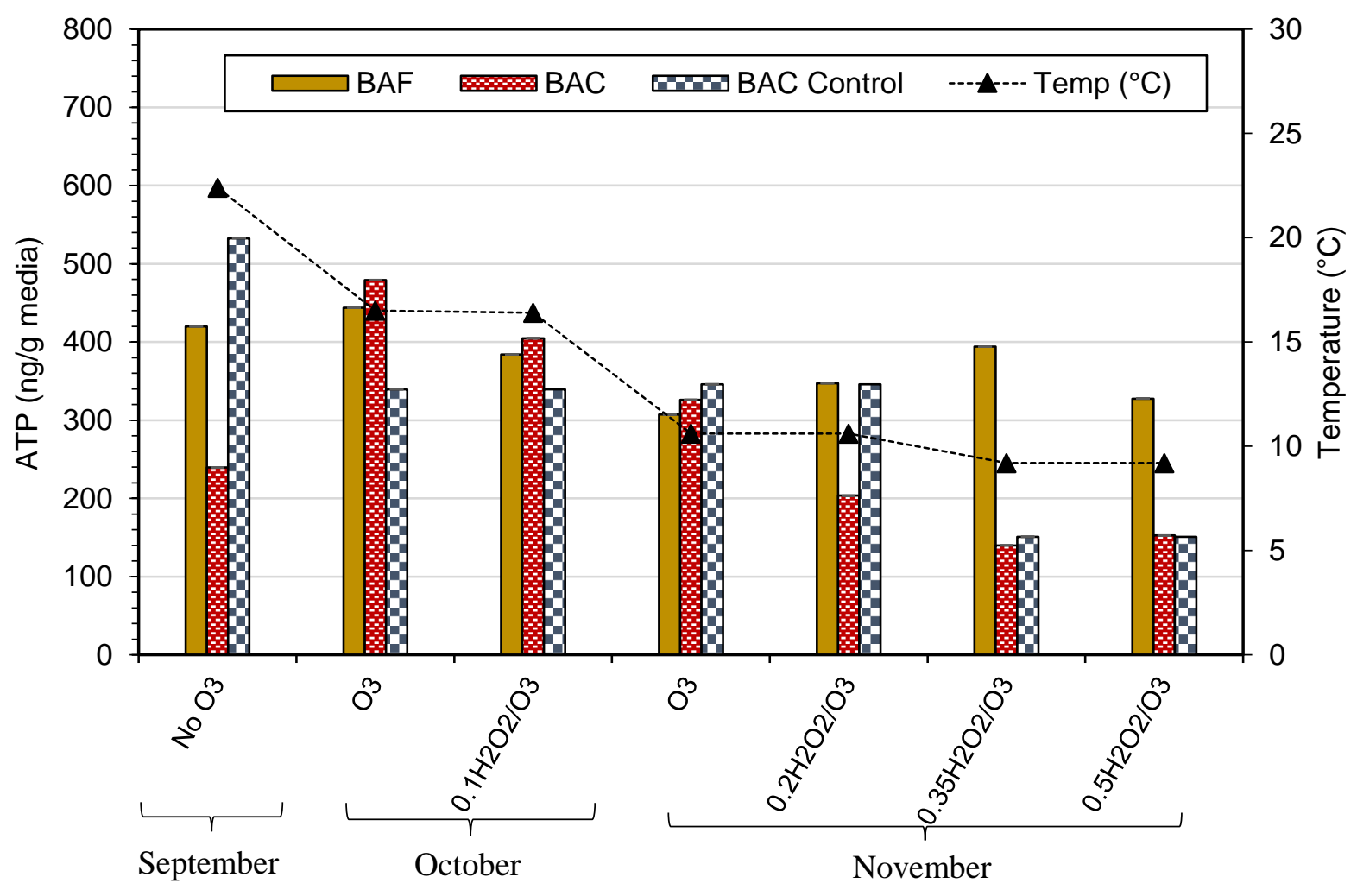

Figure 4-7: ATP concentrations on the surface of BAF, BAC, and BAC control 


\subsection{Summary}

This pilot study evaluated the effectiveness of $\mathrm{O}_{3}$ and $\mathrm{H}_{2} \mathrm{O}_{2} / \mathrm{O}_{3}$ advanced oxidation in combination with biofiltration for geosmin and MIB control, organic carbon removal (DOC, $\mathrm{UV}_{254}$, and LC-OCD), and DBP (THM and HAA) formation potential reduction. This study compared two media types (biologically active carbon (BAC) and biologically active anthracite (BAF)) while investigating the impact of pre-oxidation with $\mathrm{O}_{3}(2 \mathrm{mg} / \mathrm{L})$ and varying $\mathrm{H}_{2} \mathrm{O}_{2} / \mathrm{O}_{3}$ ratios $(0.1,0.2,0.35$, and $0.5 \mathrm{mg} / \mathrm{mg})$ with respect to geosmin, MIB, and DBP precursor removal efficiency. In addition, performance of biofiltration was compared with conventional treatment while continuously operating the parallel filter trains.

Biofiltration using BAC was effective in achieving geosmin and MIB removal (>80\%) in warmer water conditions $\left(22^{\circ} \mathrm{C}\right) . \mathrm{O}_{3}$ efficiency and $\mathrm{BAC}$ biodegradation rates were significantly impacted in cold water conditions $\left(16^{\circ} \mathrm{C}\right.$ and $\left.10^{\circ} \mathrm{C}\right)$ with respect to geosmin and MIB removal. For instance, at an $\mathrm{O}_{3}$ dose of $2 \mathrm{mg} / \mathrm{L}$, geosmin and MIB removals decreased from $70 \%$ to $45 \%$ and $55 \%$ to $40 \%$ at $16^{\circ} \mathrm{C}$ and $10^{\circ} \mathrm{C}$, respectively. Similarly, MIB removals across BAC without preoxidation decreased from $85 \%$ to $46 \%$ at $22^{\circ} \mathrm{C}$ and $10^{\circ} \mathrm{C}$, respectively. Geosmin removal was sensitive to $\mathrm{O}_{3}$ oxidation and $0.2 \mathrm{H}_{2} \mathrm{O}_{2} / \mathrm{O}_{3}(\mathrm{mg} / \mathrm{mg})$ prior to $\mathrm{BAC}$ provided an additional barrier at colder water conditions $\left(10^{\circ} \mathrm{C}\right)$. At similar water temperatures, pre-oxidation using $(0.2-0.5)$ $\mathrm{H}_{2} \mathrm{O}_{2} / \mathrm{O}_{3}(\mathrm{mg} / \mathrm{mg}$ ) ratios were required to achieve effective MIB control (>80\%).

In terms of DBPFP, the application of $\mathrm{O}_{3}$ and $\mathrm{H}_{2} \mathrm{O}_{2} / \mathrm{O}_{3}$ resulted in lower DBPFP compared to conventional treatment. For instance, $\mathrm{O}_{3}$ decreased THMFP and HAAFP by an average of $10 \%$ and $12 \%$, respectively. $\mathrm{H}_{2} \mathrm{O}_{2} / \mathrm{O}_{3}$ when averaged over four ratios $(0.1,0.2,0.35$, and $0.5 \mathrm{mg} / \mathrm{mg})$ observed THMFP and HAAFP reductions of $13 \%$ and $8 \%$, respectively from settled water. Reduction in THMFP was associated with reduction in building blocks which act as THM precursors and correlated well with THMFP concentrations. Except in few instances, $\mathrm{H}_{2} \mathrm{O}_{2} / \mathrm{O}_{3}$ observed no significant difference on THM/HAAFP reductions when compared to $\mathrm{O}_{3}$. These results imply that peroxide addition is beneficial for geosmin and MIB control even in cold water conditions $\left(10^{\circ} \mathrm{C}\right)$ but we observed no significant impact on HAAFP reduction compared to $\mathrm{O}_{3}$ at the conditions that were tested. 


\section{Conclusions and Recommendations}

\subsection{Conclusions}

- Biofiltration using BAC can be an effective treatment process for geosmin and MIB removal $(>80 \%)$ at warmer water conditions $\left(22^{\circ} \mathrm{C}\right)$ but less effective at lower water temperatures $\left(16^{\circ} \mathrm{C}\right.$ and $\left.10^{\circ} \mathrm{C}\right)$.

- Application of $\mathrm{O}_{3}$ prior to biofiltration (BAC) can achieve removals to $<10 \mathrm{ng} / \mathrm{L}$ for geosmin at $16^{\circ} \mathrm{C}$ and $10^{\circ} \mathrm{C}$, but at $10^{\circ} \mathrm{C}$ the application of $0.2 \mathrm{H}_{2} \mathrm{O}_{2} / \mathrm{O}_{3}(\mathrm{mg} / \mathrm{mg})$ resulted in optimal removal for both geosmin and MIB.

- Results from this study indicate that geosmin is sensitive to $\mathrm{O}_{3}$ whereas MIB is sensitive to $\cdot \mathrm{OH}$ oxidation.

- $\mathrm{O}_{3}$ decreased THMFP and HAAFP by an average of $10 \%$ and $12 \%$, respectively whereas, $\mathrm{H}_{2} \mathrm{O}_{2} / \mathrm{O}_{3}$ values averaged over four ratios $(0.1,0.2,0.35$, and 0.5$)$ observed $13 \%$ THMFP and $8 \%$ HAAFP reductions, respectively from settled water.

- When compared to $\mathrm{O}_{3}, \mathrm{H}_{2} \mathrm{O}_{2}$ addition observed no significant difference on THMFP and HAAFP reductions except for 0.1 and $0.5 \mathrm{H}_{2} \mathrm{O}_{2} / \mathrm{O}_{3}$ ratios. These results imply that the peroxide addition is beneficial for geosmin and MIB control at cold water conditions but we observed no significant impact on HAAFP reduction.

\subsection{Recommendations}

- While $\mathrm{O}_{3}(2 \mathrm{mg} / \mathrm{L})$ and $0.2 \mathrm{H}_{2} \mathrm{O}_{2} / \mathrm{O}_{3}(\mathrm{mg} / \mathrm{mg})$ advanced oxidation observed to achieve multiple treatment objectives including T\&O control, organic and DBP (THM and HAA) precursor reduction, future studies are recommended to assess the impact of pre-oxidation in combination with biofiltration on other DBP groups such as haloacetonitriles, trihalonitromethanes, and haloketones.

- $\mathrm{O}_{3}$ treatment involves quenching of any available residual prior to biofiltration using a reducing agent. This reducing agent can impact chlorine demand during the disinfection process. Future 
studies should be designed with respect to maintaining a minimal residual by selecting the $\mathrm{O}_{3}$ dose based on settled water demand.

- To account for seasonal variability, long term DBP formation studies are suggested using $\mathrm{O}_{3}$ and $\mathrm{H}_{2} \mathrm{O}_{2} / \mathrm{O}_{3}$ advanced oxidation prior to biofiltration.

- As ozonation is a highly energy intensive process, energy consumption requirements for micropollutant oxidation is recommended for future studies.

- As $\mathrm{O}_{3}$ efficiency is dependent on temperature, $\mathrm{O}_{3}$ efficiency decreases during cold water conditions and leads to incomplete oxidation of DBP precursors, especially HAAs. Therefore, the impact of increasing the $\mathrm{O}_{3}$ contact time during cold water conditions with respect to HAAFP is recommended for future studies. 


\section{References}

Acero, J.L., Gunten, U. von, 2001. Characterization of Oxidation processes:ozonation and AOP $\mathrm{O}_{3} / \mathrm{H}_{2} \mathrm{O}_{2}$. J. Am. Water Works Assoc. 93, 90-100.

American Public Health Association (APHA), American Water Works Association (AWWA), W.E.F. (WEF), 2012. Standard Methods for the Examination of Water and Wastewater. Stand. Methods 541. doi:ISBN 9780875532356

Andreadakis, A.D., Mamais, D., Noutsopoulos, C., Kouris, N., Nikitopoulos, G., 2010. Removal of taste and odour from potable water by ozone and Powdered Activated Carbon (PAC). Int. J. Environ. Waste Manag. 5, 392-409. doi:10.1504/IJEWM.2010.032016

Antonopoulou, M., Evgenidou, E., Lambropoulou, D., Konstantinou, I., 2014. A review on advanced oxidation processes for the removal of taste and odor compounds from aqueous media. Water Res. 53, 215-234. doi:10.1016/j.watres.2014.01.028

Azzeh, J., Taylor-Edmonds, L., Andrews, R.C., 2015. Engineered biofiltration for ultrafiltration fouling mitigation and disinfection by-product precursor control. Water Sci. Technol. Water Supply 15, 124-133. doi:10.2166/ws.2014.091

Black, K.E., Bérubé, P.R., 2014. Rate and extent of NOM removal during oxidation and biofiltration. Water Res. 52, 40-50. doi:10.1016/j.watres.2013.12.017

Bruce, E., William, J., 2000. Ozone/biofiltration for removing MIB and geosmin. J. Am. Water Work. Assoc. 92, 85-95.

Carlson, K.H., Amy, G.L., 2001. Ozone and biofiltration optimization for multiple objectives. J. Am. Water Works Assoc. 93, 88-98.

Chang, E.E., Liang, C.H., Ko, Y.W., Chiang, P.C., 2002. Effect of ozone dosage for removal of model compounds by ozone/GAC treatment. Ozone Sci. Eng. 24, 357-367. doi:10.1080/01919510208901626 
de Vera, G.A., Keller, J., Gernjak, W., Weinberg, H., Farré, M.J., 2016. Biodegradability of DBP precursors after drinking water ozonation. Water Res. 106, 550-561. doi:10.1016/j.watres.2016.10.022

de Vera, G.A., Stalter, D., Gernjak, W., Weinberg, H.S., Keller, J., Farré, M.J., 2015. Towards reducing DBP formation potential of drinking water by favouring direct ozone over hydroxyl radical reactions during ozonation. Water Res. 87, 49-58. doi:10.1016/j.watres.2015.09.007

Dussert, B.W., Tramposch, W.G., 1997. Impact of Support Media on the Biological Treatment of Ozonated Drinking Water. Ozone Sci. Eng. 19, 97-108. doi:10.1080/01919519708547308

Elhadi, L.N.S., Huck, M.P., Slawson, M.R., 2006. Factors affecting the removal of geosmin and MIB in drinking water biofilters. J. AWWA 16, 381-389.

Elhadi, S.L.N., Huck, P.M., Slawson, R.M., 2004. Removal of geosmin and 2-methylisoborneol by biological filtration. Water Sci. Technol. 49, 273-280.

Elovitz, M.S., von Gunten, U., Kaiser, H.-P., 2000. Hydroxyl Radical/Ozone Ratios During Ozonation Processes. II. The Effect of Temperature, pH, Alkalinity, and DOM Properties. Ozone Sci. Eng. 22, 123-150. doi:10.1080/01919510008547216

Emelko, M.B., Huck, P.M., Coffey, B.M., Smith, E.F., 2006. Effects of media, backwash, and temperature on full-scale biological filtration. J. Am. Water Work. Assoc. 98, 61-73.

Fabris, R., Chow, C.W.K., Drikas, M., Eikebrokk, B., 2008. Comparison of NOM character in selected Australian and Norwegian drinking waters. Water Res. 42, 4188-4196. doi:10.1016/j.watres.2008.06.023

Ferguson, D.W., Mcguire, M.J., Koch, B., Wolfe, R.L., Aieta, E.M., 1990. Comparing Peroxone and ozone for controlling taste and odour compounds, disinfection by-products, and microorganisms. J. Am. Water Works Assoc. 82, 181-191.

Gardoni, D., Vailati, a., Canziani, R., 2012. Decay of Ozone in Water: A Review. Ozone Sci. Eng. 34, 233-242. doi:10.1080/01919512.2012.686354 
Glaze, W.H., Schep, R., Chauncey, W., Ruth, E.C., Zarnoch, J.J., Aieta, E.M., Tate, C.H., McGuire, M.J., 1990. Evaluating oxidants for the removal of model taste and odor compounds from a municipal water supply. J. Am. Water Work. Assoc. 82, 79-84. doi:10.2307/41292908

Gillogly, T.E.T., Snoeyink, V.L., Vogel, J.C., Wilson, C.M., Royal, E.P., 1999. Determining GAC bed life. J. AWWA 91, 98-110.

Glaze, W.H., Schep, R., Chauncey, W., Ruth, E.C., Zarnoch, J.J., Aieta, E.M., Tate, C.H., McGuire, M.J., 1990. Evaluating oxidants for the removal of model taste and odor compounds from a municipal water supply. J. Am. Water Work. Assoc. 82, 79-84. doi: $10.2307 / 41292908$

Guo, Q., Yang, K., Yu, J., Wang, C., Wen, X., Zhang, L., Yang, M., Xia, P., Zhang, D., 2016. Simultaneous removal of multiple odorants from source water suffering from septic and musty odors: Verification in a full-scale water treatment plant with ozonation. Water Res. 100, 1-6. doi:10.1016/j.watres.2016.05.017

Ho, L., Hoefel, D., Bock, F., Saint, C.P., Newcombe, G., 2007. Biodegradation rates of 2methylisoborneol (MIB) and geosmin through sand filters and in bioreactors. Chemosphere 66, 2210-2218. doi:10.1016/j.chemosphere.2006.08.016

Ho, L., Newcombe, G., 2010. Granular Activated Carbon Adsorption of 2-Methylisoborneol (MIB): Pilot- and Laboratory-Scale Evaluations. J. Environ. Eng. 136, 965-974. doi:10.1061/(ASCE)EE.1943-7870.0000231

Ho, L., Newcombe, G., Croué, J.P., 2002. Influence of the character of NOM on the ozonation of MIB and geosmin. Water Res. 36, 511-518. doi:10.1016/S0043-1354(01)00253-6

Hoigné, J., Bader, H., 1979. Ozonation of Water: “Oxidation-Competition Values” of Different Types of Waters Used in Switzerland. Ozone Sci. Eng. 1, 357-372. doi:10.1080/01919512.1979.10684571 
Hrudey, S.E., Payment, P., Huck, P.M., Gillham, R.W., Hrudey, E.J., 2003. A fatal waterborne disease epidemic in Walkerton, Ontario: Comparison with other waterborne outbreaks in the developed world. Water Sci. Technol. 47, 7-14.

Huber, S.A., Balz, A., Abert, M., Pronk, W., 2011. Characterisation of aquatic humic and nonhumic matter with size-exclusion chromatography - organic carbon detection - organic nitrogen detection (LC-OCD-OND). Water Res. 45, 879-885. doi:10.1016/j.watres.2010.09.023

Kim, J., 2009. Fate of THMs and HAAs in low TOC surface water. Environ. Res. 109, 158-165. doi:10.1016/j.envres.2008.11.003

Klausen, M.M., Grønborg, O., 2010. Pilot scale testing of advanced oxidation processes for degradation of geosmin and MIB in recirculated aquaculture. Water Sci. Technol. Water Supply 10, 217-225. doi:10.2166/ws.2010.246

Kleiser, G., Frimmel, F.H., 2000. Removal of precursors for disinfection by-products (DBPs)— differences between ozone-and OH-radical-induced oxidation. Sci. Total Environ. 256, 1-9.

Knol, A.H., Lekkerkerker-Teunissen, K., Houtman, C.J., Scheideler, J., Ried, A., Van Dijk, J.C., 2015. Conversion of organic micropollutants with limited bromate formation during the Peroxone process in drinking water treatment. Drink. Water Eng. Sci. 8, 25-34. doi:10.5194/dwes-8-25-2015

Korotta-Gamage, S.M., Sathasivan, A., 2017. A review: Potential and challenges of biologically activated carbon to remove natural organic matter in drinking water purification process. Chemosphere 167, 120-138. doi:10.1016/j.chemosphere.2016.09.097

Lautenschlager, K., Hwang, C., Ling, F., Liu, W.T., Boon, N., Köster, O., Egli, T., Hammes, F., 2014. Abundance and composition of indigenous bacterial communities in a multi-step biofiltration-based drinking water treatment plant. Water Res. 62, 40-52. doi:10.1016/j.watres.2014.05.035 
Lee, C.O., Howe, K.J., Thomson, B.M., 2012. Ozone and biofiltration as an alternative to reverse osmosis for removing PPCPs and micropollutants from treated wastewater. Water Res. 46, 1005-1014. doi:10.1016/j.watres.2011.11.069

Lee, Y., von Gunten, U., 2016. Advances in predicting organic contaminant abatement during ozonation of municipal wastewater effluent: reaction kinetics, transformation products, and changes of biological effects. Environ. Sci. Water Res. Technol. 2, 421-442. doi:10.1039/C6EW00025H

Li, X., Lin, P., Wang, J., Liu, Y., Li, Y., Zhang, X., Chen, C., 2015. Treatment technologies and mechanisms for three odorants at trace level: IPMP, IBMP, and TCA. Environ. Technol. 37, 308-315. doi:10.1080/09593330.2015.1069405

Li, Z., Hobson, P., An, W., Burch, M.D., House, J., Yang, M., 2012. Earthy odor compounds production and loss in three cyanobacterial cultures. Water Res. 46, 5165-5173. doi:10.1016/j.watres.2012.06.008

Liang, S., Maceiko, S.M., Takeguchi, W.A., Yates, R.S., 2014. Bench-scale ozonation for removing constituents of emerging concern. J. Am. Water Works Assoc. 106, 89-90. doi:10.5942/jawwa.2014.106.0063

Magic-Knezev, A., van der Kooij, D., 2004. Optimisation and significance of ATP analysis for measuring active biomass in granular activated carbon filters used in water treatment. Water Res. 38, 3971-3979. doi:10.1016/j.watres.2004.06.017

McKie, M.J., Taylor-Edmonds, L., Andrews, S.A., Andrews, R.C., 2015. Engineered biofiltration for the removal of disinfection by-product precursors and genotoxicity. Water Res. 81, 196207. doi:10.1016/j.watres.2015.05.034

Mizuno, T., Ohara, S., Nishimura, F., Tsuno, H., 2011. O3/H2O2 Process for Both Removal of Odorous Algal-Derived Compounds and Control of Bromate Ion Formation. Ozone-Science Eng. 33, 121-135. doi:10.1080/01919512.2011.548200 
Moll, D.M., Summers, R.S., Fonseca, A.C., Matheis, W., 1999. Impact of Temperature on Drinking Water Biofilter Performance and Microbial Community Structure. Environ. Sci. Technol. 33, 2377-2382. doi:10.1021/es9900757

Newcombe, G., House, J., Ho, L., Baker, P., Burch, M., 2010. Management Strategies for Cyanobacteria (Blue-Green Algae): A Guide for Water Utilities. Water Qual. Res. Aust. Research R, 101.

Olsen, B.K., Chislock, M.F., Wilson, A.E., 2016. Eutrophication mediates a common off-flavor compound, 2-methylisoborneol, in a drinking water reservoir. Water Res. 92, 228-234. doi:10.1016/j.watres.2016.01.058

Parinet, J., Rodriguez, M.J., Sérodes, J., 2010. Influence of water quality on the presence of offflavour compounds (geosmin and 2-methylisoborneol). Water Res. 44, 5847-5856. doi:10.1016/j.watres.2010.06.070

Park, G., Yu, M., Go, J., Kim, E., Kim, H., 2007. Comparison between ozone and ferrate in oxidising geosmin and 2-MIB in water. Water Sci. Technol. 55, 117-125. doi:10.2166/wst.2007.170

Park, H., Kim, T.Y., Woo, D., Cho, Y.S., 2015. Comparison of O3 + GAC, O3 + H2O2 + GAC, and GAC unit operation on natural organic matter and taste and odor causing compounds removal using a pilot plant study. Water Sci. Technol. Water Supply 15, 1383-1395. doi:10.2166/ws.2015.102

Persson, F., Heinicke, G., Uhl, W., Hedberg, T., Hermansson, M., 2006. Performance of direct biofiltration of surface water for reduction of biodegradable organic matter and biofilm formation potential. Environ. Technol. 27, 1037-45. doi:10.1080/09593332708618717

Peter, A., Von Gunten, U., 2007. Oxidation kinetics of selected taste and odor compounds during ozonation of drinking water. Environ. Sci. Technol. 41, 626-631. doi:10.1021/es061687b

Pharand, L., Van Dyke, M.I., Anderson, W.B., Huck, P.M., 2014. Assessment of biomass in drinking water Biofilters by Adenosine triphosphate. J. Am. Water Works Assoc. 106, E433E444. doi:10.5942/jawwa.2014.106.0107 
Pharand, L., Van Dyke, M.I., Anderson, W.B., Yohannes, Y., Huck, P.M., 2015. Full-scale ozone - biofiltration: Seasonally related effects on NOM removal. J. Am. Water Works Assoc. 425435. doi:10.5942/jawwa.2015.107.0121

Plumlee, M.H., Stanford, B.D., Debroux, J.-F., Hopkins, D.C., Snyder, S.A., 2014. Costs of Advanced Treatment in Water Reclamation. Ozone Sci. Eng. 36, 485-495. doi:10.1080/01919512.2014.921565

PWTP, 2015. Peterborough Utilities Commission 2015 Water Quality Report.

Ramseier, M.K., von Gunten, U., 2009. Mechanisms of Phenol Ozonation-Kinetics of Formation of Primary and Secondary Reaction Products. Ozone Sci. Eng. 31, 201-215. doi:10.1080/01919510902740477

Rice, R.G., Overbeck, P.K., 1998. Ozone and the Safe Drinking Water Act 1-22.

Sánchez-Polo, M., Salhi, E., Rivera-Utrilla, J., von Gunten, U., 2006. Combination of Ozone with Activated Carbon as an Alternative to Conventional Advanced Oxidation Processes. Ozone Sci. Eng. 28, 237-245. doi:10.1080/01919510600714170

Schulz, C.R., 2014. Designing Integrated Ozone-Biofiltration Treatment Systems. Ozone Sci. Eng. 36, 276-286. doi:10.1080/01919512.2014.904741

Seredyńska-Sobecka, B., Tomaszewska, M., Morawski, A.W., 2006. Removal of humic acids by the ozonation-biofiltration process. Desalination 198, 265-273. doi:10.1016/j.desal.2006.01.027

Sonntag, C. von, Gunten, U. von, 2012. Chemistry of ozone in water and wastewater treatment: from basic principles to applications. IWA Publishing, London, UK.

Srinivasan, R., Sorial, G.A., 2011. Treatment of taste and odor causing compounds 2-methyl isoborneol and geosmin in drinking water: A critical review. J. Environ. Sci. 23, 1-13. doi:10.1016/S1001-0742(10)60367-1 
Swietlik, J., Dabrowska, A., Raczyk-Stanisławiak, U., Nawrocki, J., 2004. Reactivity of natural organic matter fractions with chlorine dioxide and ozone. Water Res. 38, 547-58. doi:10.1016/j.watres.2003.10.034

Urfer, D., Huck, P.M., Booth, S.D.J., Coffey, B.M., 1997. Biological filtration for BOM and particle removal: a critical review. J. - AWWA 89, 83-98.

USEPA, 2006. National Primary Drinking Water Regulations: Stage 2 Disinfectants and Disinfection Byproducts Rule; Final Rule. Fed. Regist. 71, 459-464.

von Gunten, U., 2003. Ozonation of drinking water: part I. Oxidation kinetics and product formation. Water Res. 37, 1443-1467. doi:10.1016/S0043-1354(02)00457-8

von Gunten, U., Oliveras, Y., 1998. Advanced Oxidation of Bromide-Containing Waters : Bromate Formation Mechanisms. Environ. Sci. Technol. 32, 63-70. doi:10.1021/es970477j

van der Wielen, P.W.J.J., van der Kooij, D., 2010. Effect of water composition, distance and season on the adenosine triphosphate concentration in unchlorinated drinking water in the Netherlands. Water Res. 44, 4860-4867. doi:10.1016/j.watres.2010.07.016

Vasyukova, E., Proft, R., Jousten, J., Slavik, I., Uhl, W., 2013. Removal of natural organic matter and trihalomethane formation potential in a full-scale drinking water treatment plant. Water Sci. Technol. Water Supply 13, 1099-1108. doi:10.2166/ws.2013.095

Velten, S., Boller, M., Köster, O., Helbing, J., Weilenmann, H.U., Hammes, F., 2011. Development of biomass in a drinking water granular active carbon (GAC) filter. Water Res. 45, 6347-6354. doi:10.1016/j.watres.2011.09.017

Wang, J., Ried, A., Stapel, H., Zhang, Y., Chen, M., Ang, W.S., Xie, R., Duarah, A., Zhang, L., Lim, M.H., 2015. A pilot-scale investigation of ozonation and advanced oxidation processes at Choa Chu Kang Waterworks. Water Pract. Technol. 10, 43-49. doi:10.2166/wpt.2015.006

Westerhoff, P., Chao, P., Mash, H., 2004. Reactivity of natural organic matter with aqueous chlorine and bromine. Water Res. 38, 1502-1513. doi:10.1016/j.watres.2003.12.014 
Westerhoff, P., Nalinakumari, B., Pei, P., 2006. Kinetics of MIB and Geosmin Oxidation during Ozonation. Ozone Sci. Eng. 28, 277-286. doi:10.1080/01919510600892836

Yan, M., Wang, D., Ma, X., Ni, J., Zhang, H., 2010. THMs precursor removal by an integrated process of ozonation and biological granular activated carbon for typical Northern China water. Sep. Purif. Technol. 72, 263-268. doi:10.1016/j.seppur.2010.02.015

Yang, J.S., Yuan, D.X., Weng, T.P., 2010. Pilot study of drinking water treatment with GAC, O3/BAC and membrane processes in Kinmen Island, Taiwan. Desalination 263, 271-278. doi:10.1016/j.desal.2010.06.069

Yuan, B., Xu, D., Li, F., Fu, M.L., 2013. Removal efficiency and possible pathway of odor compounds (2-methylisoborneol and geosmin) by ozonation. Sep. Purif. Technol. 117, 5358. doi:10.1016/j.seppur.2013.04.029

Zha, X. song, Ma, L. ming, Wu, J., Liu, Y., 2016. The removal of organic precursors of DBPs during three advanced water treatment processes including ultrafiltration, biofiltration, and ozonation. Environ. Sci. Pollut. Res. 23, 16641-16652. doi:10.1007/s11356-016-6643-z

Zhou, B., Yuan, R., Shi, C., Yu, L., Gu, J., Zhang, C., 2011. Biodegradation of geosmin in drinking water by novel bacteria isolated from biologically active carbon. J. Environ. Sci. 23, 816823. doi:10.1016/S1001-0742(10)60458-5

Zhu, I.X., Getting, T., Bruce, D., 2010. Review of biologically active filters in drinking water applications. J. Am. Water Work. Assoc. 102, 67-77.

Zietzschmann, F., Mitchell, R.L., Jekel, M., 2015. Impacts of ozonation on the competition between organic micro-pollutants and effluent organic matter in powdered activated carbon adsorption. Water Res. 84, 153-160. doi:10.1016/j.watres.2015.07.031

Zimmermann, S.G., Wittenwiler, M., Hollender, J., Krauss, M., Ort, C., Siegrist, H., von Gunten, U., 2011. Kinetic assessment and modeling of an ozonation step for full-scale municipal wastewater treatment: Micropollutant oxidation, by-product formation and disinfection. Water Res. 45, 605-617. doi:10.1016/j.watres.2010.07.080 


\section{Appendices}

\subsection{Calibration Curves}

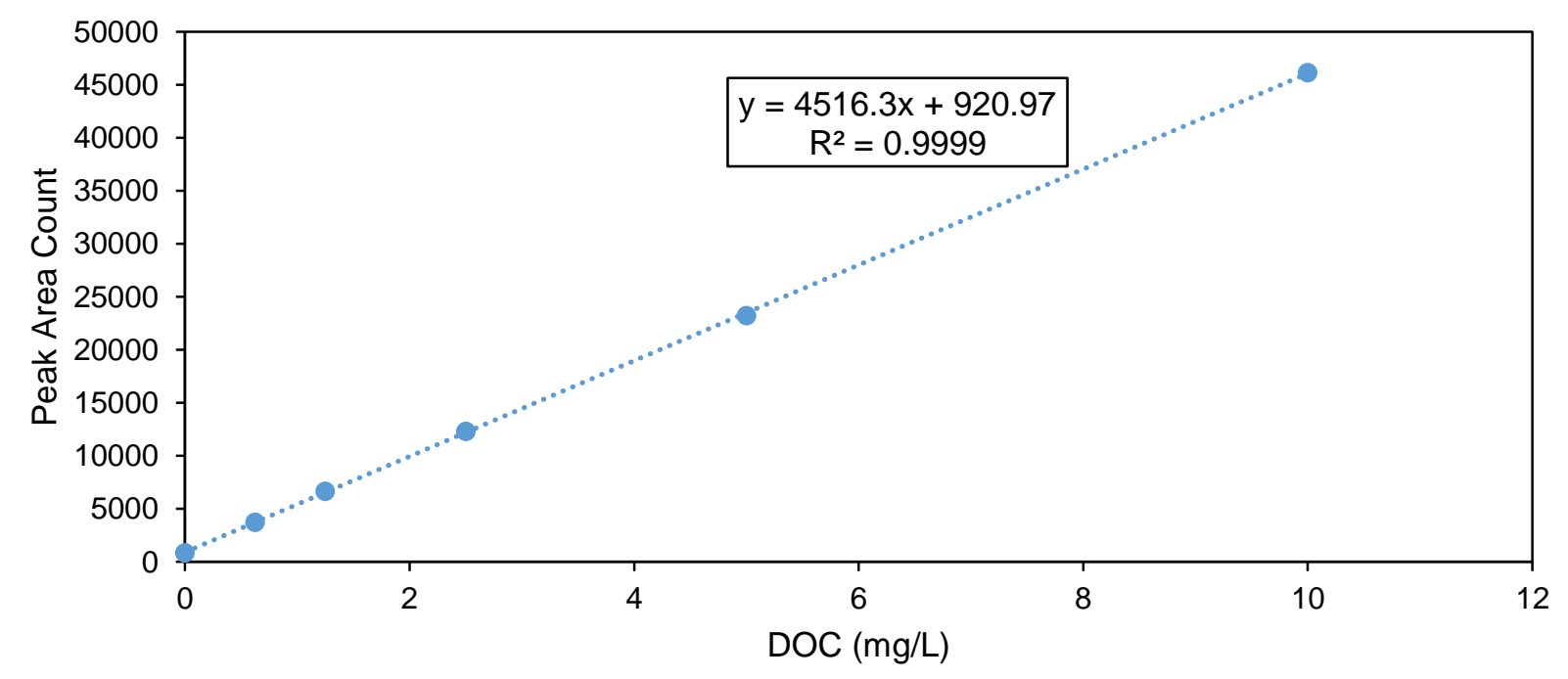

Figure 7-1: Sample DOC Calibration Curve (May 2016)

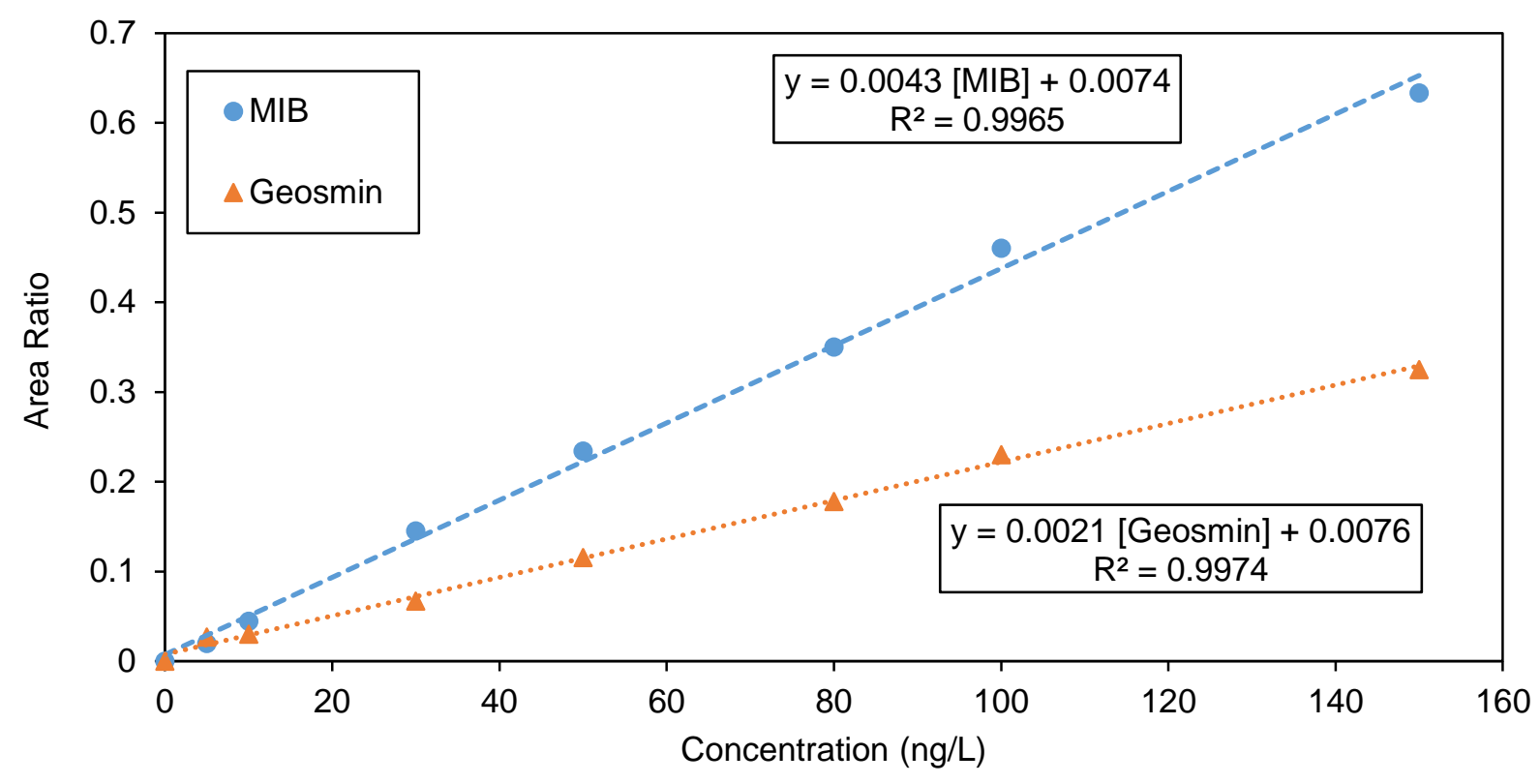

Figure 7-2: Sample Geosmin and MIB Calibration Curve (August 2016) 


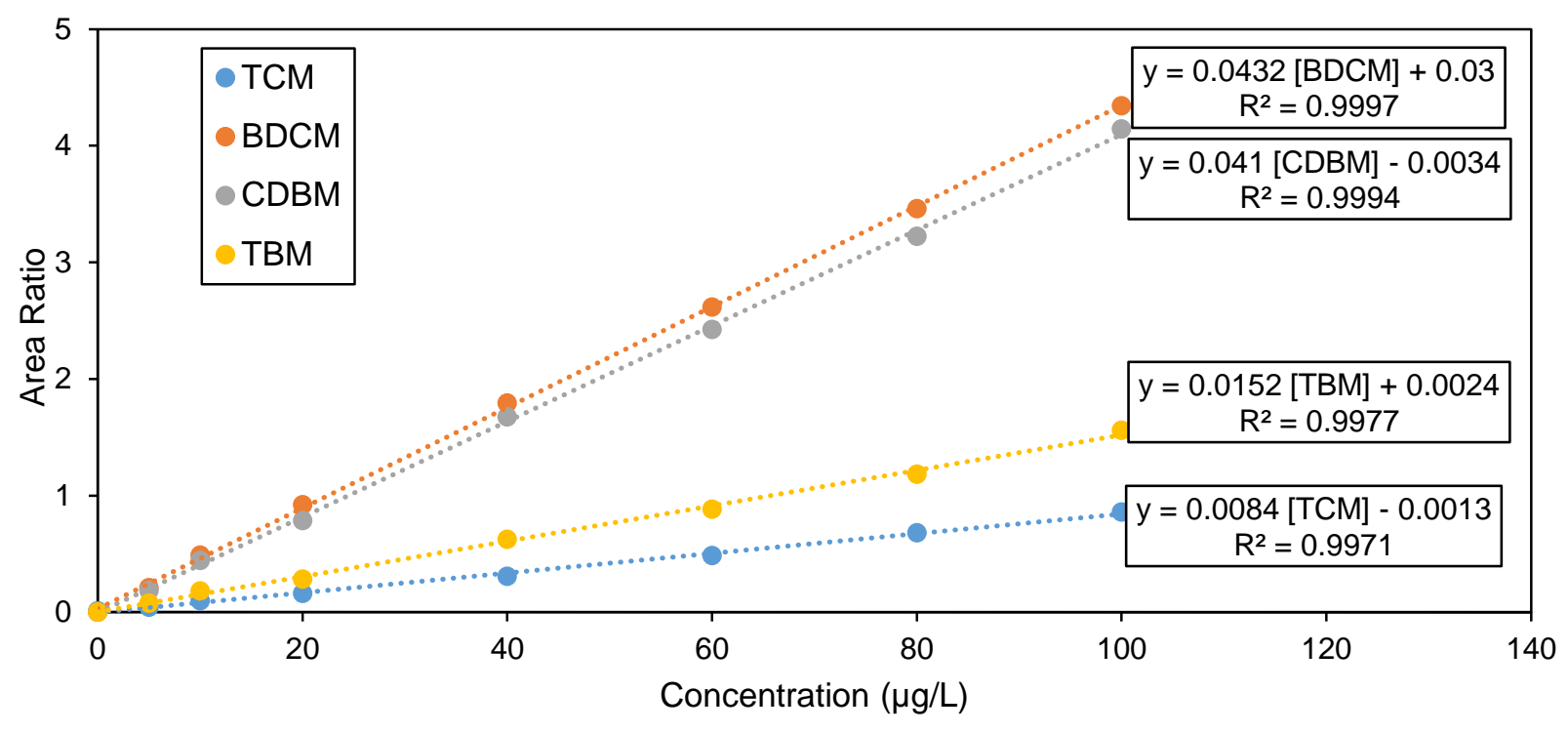

Figure 7-3: Sample THM Calibration Curve (June 2016)

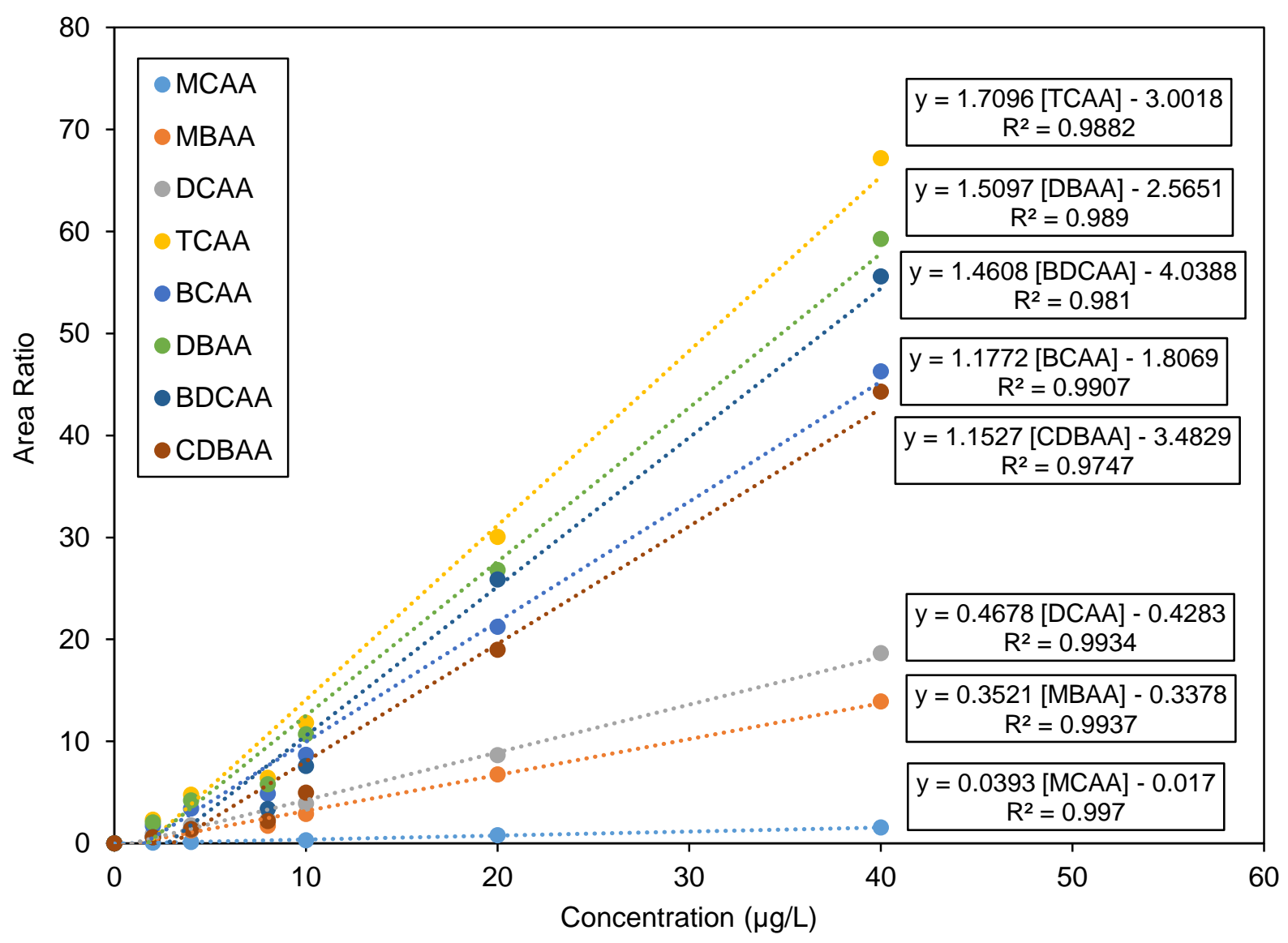

Figure 7-4: Sample HAA Calibration Curve (June 2016) 


\subsection{Standard Operating Procedure Outline}

The following tables outlines the procedure that was used for sample preparation and analysis during the study. Information for the analysis of ATP (Table 7-1), DOC (Table 7-2), geosmin and 2-methylisoborneol (MIB) (Table 7-3), trihalomethanes (THMs) (Table 7-4), haloacetic acids (HAAs) (Table 7-5).

Table 7-1: ATP Analysis Procedure

\section{Calibration}

1. Add $100 \mu \mathrm{L}$ of enzyme reagent (Luminase) and $100 \mu \mathrm{L}$ of ATP standard (Ultracheck 1) in a $12 \times 55 \mathrm{~mm}$ test tube

2. Measure the relative light units (RLU) using the luminometer (RLUstandard)

\section{Sample Analysis}

1. Weigh $1 \mathrm{~g}$ of sample and transfer to a $5 \mathrm{~mL}$ (pre-packaged) UltraLyse ${ }^{\mathrm{TM}} 7$ tube and mix

2. Wait for 5 minutes

3. Transfer $1 \mathrm{~mL}$ of the UltraLyse ${ }^{\mathrm{TM}} 7$ solution to a $9 \mathrm{~mL}$ (pre-packaged) UltraLute vial

4. After mixing the UltraLute solution, pipette $100 \mu \mathrm{L}$ to a new $12 \times 55 \mathrm{~mm}$ test tube.

5. Add $100 \mu \mathrm{L}$ of Luminase and gently swirl 5 times

6. Place the test tube into the luminometer and measure the RLU (RLU $\left.U_{\text {sample }}\right)$

7. Determine ATP concentration using the following equation:

$$
A T P\left(\frac{p g A T P}{g \text { media }}\right)=\frac{R L U_{\text {sample }}}{R L U_{\text {standard }}} \times \frac{50,000(p g A T P)}{\text { mass }_{\text {sample }}(g)}
$$


Table 7-2: DOC Analysis Procedure

\section{Blanks}

Use $40 \mathrm{~mL}$ of Milli-Q®

\section{Stock Solution}

Mix 2.13 g potassium hydrogen phthalate in $1 \mathrm{~L}$ Milli-Q ${ }^{\circledR}$ water. Store at $\mathrm{pH} \leq 2$ by acidifying with $\mathrm{H}_{2} \mathrm{SO}_{4}$.

\section{Calibration Solution (10 $\mathrm{mg} / \mathrm{L})$}

Add $1 \mathrm{~mL}$ of stock solution to $99 \mathrm{~mL}$ of Milli-Q® water.

\section{Check Standard $(2.5 \mathrm{mg} / \mathrm{L})$}

Add $250 \mu \mathrm{L}$ of stock solution to $99.75 \mathrm{~mL}$ Milli-Q® water.

\section{Samples}

Follow SOP for TOC analyzer.

Table 7-3: Geosmin and MIB Extraction and Analysis Procedure

\section{Sample Collection}

1. Add $166 \mu \mathrm{L}$ of $25 \mathrm{~g} / \mathrm{L}$ Reagent Plus ${ }^{\circledR}, \geq 99.5 \%$ sodium azide solution in $23 \mathrm{~mL}$ sampling amber vials.

2. Collect samples in these amber vials with Teflon ${ }^{\circledR}$-lined septa screw caps, ensuring that the sample is headspace free.

3. Store samples in the dark at $4^{0} \mathrm{C}$ for up to 14 days before analysis.

4. Remove from refrigerator and bring to room temperature before preparation

\section{Standard preparation}

1. Pipette $10 \mathrm{~mL}$ of Milli- ${ }^{\circledR}$ water into a sample extraction vial that contains $3.5 \mathrm{~g}$ of $\mathrm{NaCl}$.

2. Inject the appropriate volume of $10 \mu \mathrm{g} / \mathrm{L}$ combined geosmin and MIB stock solution.

3. Spike $25 \mu \mathrm{L}$ of $10 \mu \mathrm{g} / \mathrm{L}$ internal standard ( $\mathrm{d}_{3}$-geosmin) into the vial to achieve $25 \mathrm{ng} / \mathrm{L}$.

4. Repeat the above steps and prepare $0,10,30,50,80,100,150 \mathrm{ng} / \mathrm{L}$ standard solutions.

5. Do not store; analyse immediately. 
Table 7-3: Geosmin and MIB Extraction and Analysis Procedure (continued)

\section{Blank preparation}

1. Transfer $10 \mathrm{~mL}$ of Milli-Q ${ }^{\circledR}$ water into a sample extraction vial that contains $3.5 \mathrm{~g}$ $\mathrm{NaCl}$.

2. Spike $25 \mu \mathrm{L}$ of $10 \mu \mathrm{g} / \mathrm{L}$ internal standard ( $\mathrm{d}_{3}$-geosmin) into the vial to achieve $25 \mathrm{ng} / \mathrm{L}$.

3. Analyse a blank and running standard after every 10 samples.

\section{Running standard preparation (60 $\mathrm{ng} / \mathrm{L}$ of geosmin and MIB)}

1. Pipette $10 \mathrm{~mL}$ of Milli-Q ${ }^{\circledR}$ water into a sample extraction vial that contains $3.5 \mathrm{~g} \mathrm{NaCl}$.

2. Inject $30 \mu \mathrm{L}$ of geosmin, MIB combined stock solution $(10 \mu \mathrm{g} / \mathrm{L})$ into the vial.

3. Spike $25 \mu \mathrm{L}$ of $10 \mu \mathrm{g} / \mathrm{L}$ internal standard ( $d_{3}$-geosmin) into the vial to achieve $25 \mathrm{ng} / \mathrm{L}$.

\section{Sample analysis}

1. Place samples in a sample tray connected to an autosampler. Autosampler delivers the sample to an agitator. Sample is agitated for 5 minutes at $500 \mathrm{rpm}$ at $65 \pm 1{ }^{\circ} \mathrm{C}$.

2. Sample extraction and analysis is carried out with the solid phase micro-extraction (SPME) using gas chromatograph (Varian ${ }^{\circledR}$ 3800) with a Varian ${ }^{\circledR}$ ion-trap mass spectrometer operated in electron ionization (EI) mode.

3. Follow SOP for GC/MS operation conditions

Table 7-4: THM Extraction and Analysis Procedure

\section{Sample Extraction}

1. Collect samples in $20 \mathrm{~mL}$ amber vials and quench with $0.020 \mathrm{~g}$ of ascorbic acid

2. Store samples in the dark at $4^{0} \mathrm{C}$ for up to 7 days before analysis

3. Remove from refrigerator and bring to room temperature before preparation

4. Blank preparation: Transfer $20 \mathrm{~mL}$ of Milli-Q® water into $40 \mathrm{~mL}$ vial and prepare with samples.

5. Intermediate solution: Prepare $20 \mathrm{mg} / \mathrm{L}$ THM solution by adding $10 \mathrm{~mL}$ of stock solution $(2000 \mu \mathrm{g} / \mathrm{mL})$ to $990 \mathrm{~mL}$ of Milli-Q® water. 
Table 7-4: THM Extraction and Analysis Procedure (continued)

\section{Calibration solutions:}

1. Prepare by adding the corresponding amount of intermediate solution to Milli-Q® water to achieve concentrations of $0,5,10,20,40,60,100,150$, and $200 \mu \mathrm{g} / \mathrm{L}$

**Wipe the syringe tip with a Kimwipe before measuring out of the THM stock or intermediate solutions, and before adding to intermediate and calibration solutions.

\section{Standard preparation}

1. Add $40 \mu \mathrm{L}$ of intermediate solution to $20 \mathrm{~mL}$ of Milli-Q® water in a $40 \mathrm{~mL}$ vial and process with other samples. Salt and MTBE should be added after adding intermediate solution.

2. Analyze a blank and running standard after every tenth sample.

\section{Extraction}

1. Transfer the contents of each sample vial into a clean $40 \mathrm{~mL}$ vial.

2. Add 2 scoops of sodium sulphate $\left(\mathrm{Na}_{2} \mathrm{SO}_{4}\right)$ to increase extraction efficiency. Add $4 \mathrm{~mL}$ of MTBE extraction solvent and cap with a Teflon®-lined silicon septum and cap.

3. Shake vial vigorously for 30 seconds and place vial on its side. Repeat for all samples, blanks and standards. Place samples upright in a rack and shake for 2 minutes. Let stand for 10 minutes.

4. Extract $2 \mathrm{~mL}$ from the organic layer using a Pasteur pipette and place in a $1.8 \mathrm{~mL} \mathrm{GC}$ vial filled with 2 small scoops of $\mathrm{Na}_{2} \mathrm{SO}_{4}$ (no water should remain in the vial). Use a clean pipette for each sample. Fill the vial to the top and cap immediately, ensuring there is no headspace. To ensure the MTBE phase was the only one taken, freeze the vials for 2 hours and observe that only 1 phase is visible.

5. If not analyzing immediately, freeze samples for up to 21 days.

6. Analyze using a GC-ECD 
Table 7-5: HAA Extraction and Analysis Procedure

\section{Sample Preparation}

1. Collect samples in $40 \mathrm{~mL}$ amber vials. Ensure that samples are free of headspace.

2. Store samples in the dark at $4^{0} \mathrm{C}$ for up to 9 days.

3. To begin sample preparation, remove from refrigerator and bring to room temperature.

\section{Blank Solutions}

1. Transfer $40 \mathrm{~mL}$ of Milli-Q® water into $40 \mathrm{~mL}$ vials and process with other samples

\section{Calibration Solutions}

1. Collect $20 \mathrm{~mL}$ of Milli-Q® in $40 \mathrm{~mL}$ vial

2. Using a $50 \mu \mathrm{L}$ syringe and the "sandwich" technique, add $0,5,10,20,40,60,100$, and $150 \mu \mathrm{L}$ of HAA stock $(2000 \mu \mathrm{g} / \mathrm{mL}$ each $)$

**Wipe the syringe tip with a Kimwipe before measuring out of the HAA stock and before adding the stock to other solutions.

\section{Running Standards}

3. Add $50 \mu \mathrm{L}$ of working solution to $20 \mathrm{~mL}$ of Milli-Q® water, process alongside samples.

4. Include blanks and running standards after every tenth sample.

\section{Diazomethane Preparation}

5. Set up MNNG diazomethane generation apparatus on ice using a beaker filled with crushed ice and water.

6. Add $2.5 \mathrm{~mL}$ of MTBE to outer tube of generator, and cover with tin foil before placing in ice bath.

7. Add $\sim 1.25 \mathrm{~cm}$ of diazald to inner tube of generator using large end of Pasteur pipette. Add $\sim 0.5 \mathrm{~mL}$ of methanol to cover diazald by $3 \mathrm{~mm}$ and secure cap and septum. 
Table 7-5: HAA Extraction and Analysis Procedure (continued)

8. Place O-ring in glass joint. Position inside tube firmly on top and secure clamp. Ensure that the vapour exit hole is located on the opposite side of the tube from the clamp and

9. Place clamp on the spout of the beaker. Ensure the seal is tight to maximize $\mathrm{CH}_{2} \mathrm{~N}_{2}$ generation and recovery.

10. Let cool on the ice bath for $10 \mathrm{~min}$.

11. Add $600 \mu \mathrm{L}$ of $20 \% \mathrm{NaOH}$ solution dropwise to inner tube with a gas tight syringe (1 drop/5 sec). Aim drops directly into the diazald in the bottom of the inner tube. Leave the syringe in place after all of the $\mathrm{NaOH}$ is added to avoid a hole in the septum from which $\mathrm{CH}_{2} \mathrm{~N}_{2}$ may exit. Allow $\mathrm{CH}_{2} \mathrm{~N}_{2}$ to form for 30 to 45 minutes on the ice bath.

\section{Sample Extraction}

1. Transfer $20 \mathrm{~mL}$ of sample into a clean $40 \mathrm{~mL}$ vial.

2. Add $3 \mathrm{~mL}$ of sulphuric acid $\left(\mathrm{H}_{2} \mathrm{SO}_{4}\right)$. Add $6 \mathrm{~g}$ of sodium sulphate $\left(\mathrm{Na}_{2} \mathrm{SO}_{4}\right)$. Add $5 \mathrm{~mL}$ of MTBE extraction solvent and cap with a Teflon ${ }^{\circledR}-$ lined silicon septa and screw cap.

3. Shake sample for $\sim 30$ seconds and place vial on its side. Repeat for all blanks, calibration solutions and samples.

4. Place samples upright in a rack and shake for 5 minutes. Let samples stand for 15 minutes.

5. Extract $1.5 \mathrm{~mL}$ from the organic layer and place into a $1.8 \mathrm{~mL}$ GC vial using a clean pipette for each sample. Add $150 \mu \mathrm{L}$ of diazomethane to the $\mathrm{GC}$ vial (submerging the syringe tip before injection) and seal immediately.

6. If not analyzing immediately, store the samples in a freezer $\left(-20^{\circ} \mathrm{C}\right)$ for up to 21 days. Analyze using a GC-ECD. 


\subsection{Sample Quality Assurance/Quality Control Charts}

QA/QC charts were generated by analyzing 9 samples prepared at a concentration equivalent to the expected concentrations in the samples being analyzed after each new calibration. Check standards are prepared at the same concentration, and analyzed after every 10 samples. The check standards are compared to the mean and standard deviation calculated from the original 8 samples as per Standard Method 1020 (APHA, 2005). The calibration is considered unacceptable if:

- 2 consecutive measurements fall outside of the control limit (CL) of the mean \pm 3 times the standard deviation;

- 3 out of 4 consecutive measurements were outside the warning limits (WL) of the mean \pm 2 times the standard deviation;

- 5 out of 6 consecutive measurements were outside of the mean \pm the standard deviation;

- 5 out of 6 consecutive measurements exhibited an increasing or decreasing trend; or,

- 7 consecutive samples were greater, or less, than the mean

If any of these conditions were met a new calibration curve was generated and the samples were reanalyzed. 


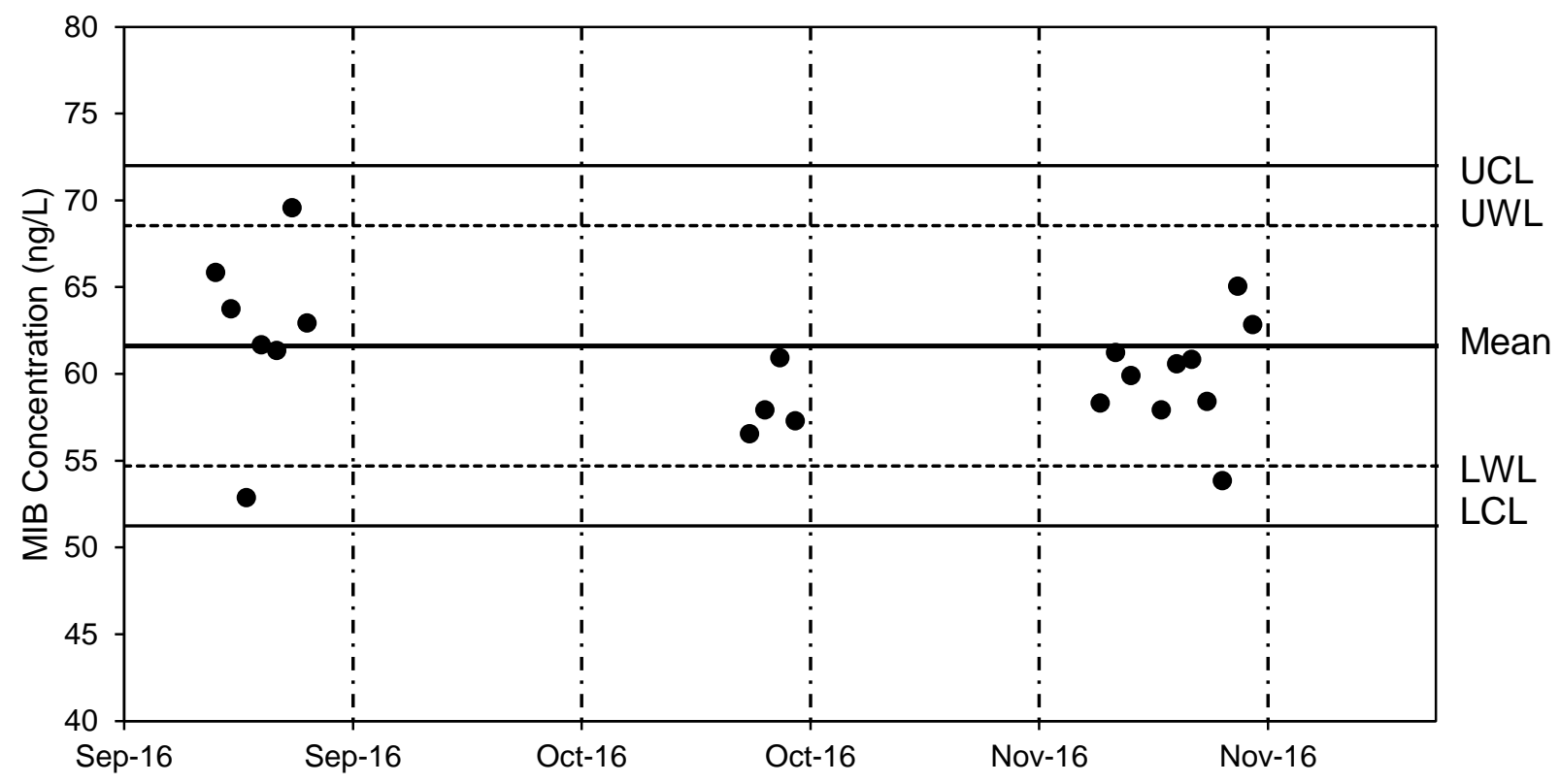

Figure 7-5: Quality Control Chart for MIB

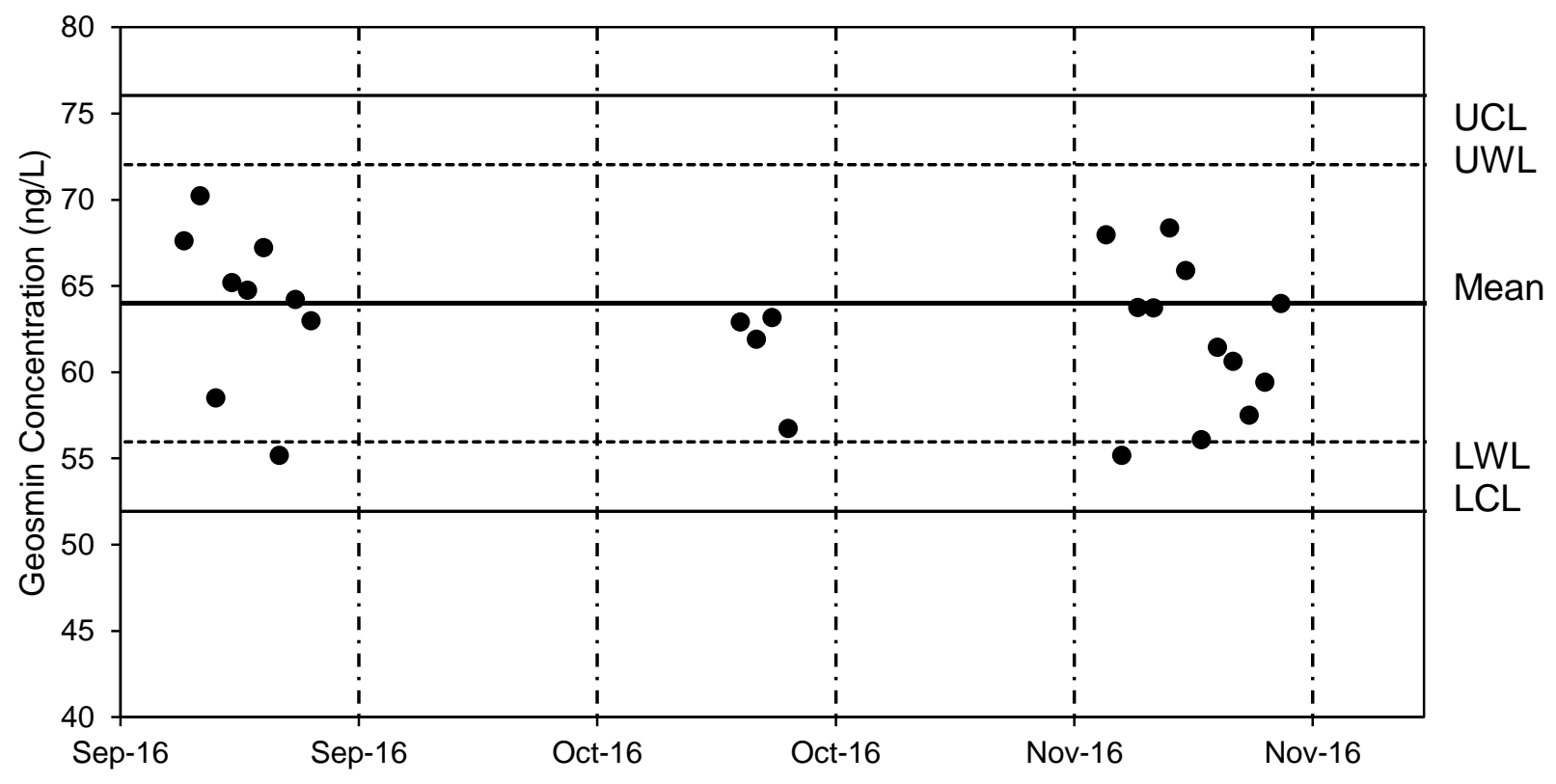

Figure 7-6: Quality Control Chart for Geosmin 


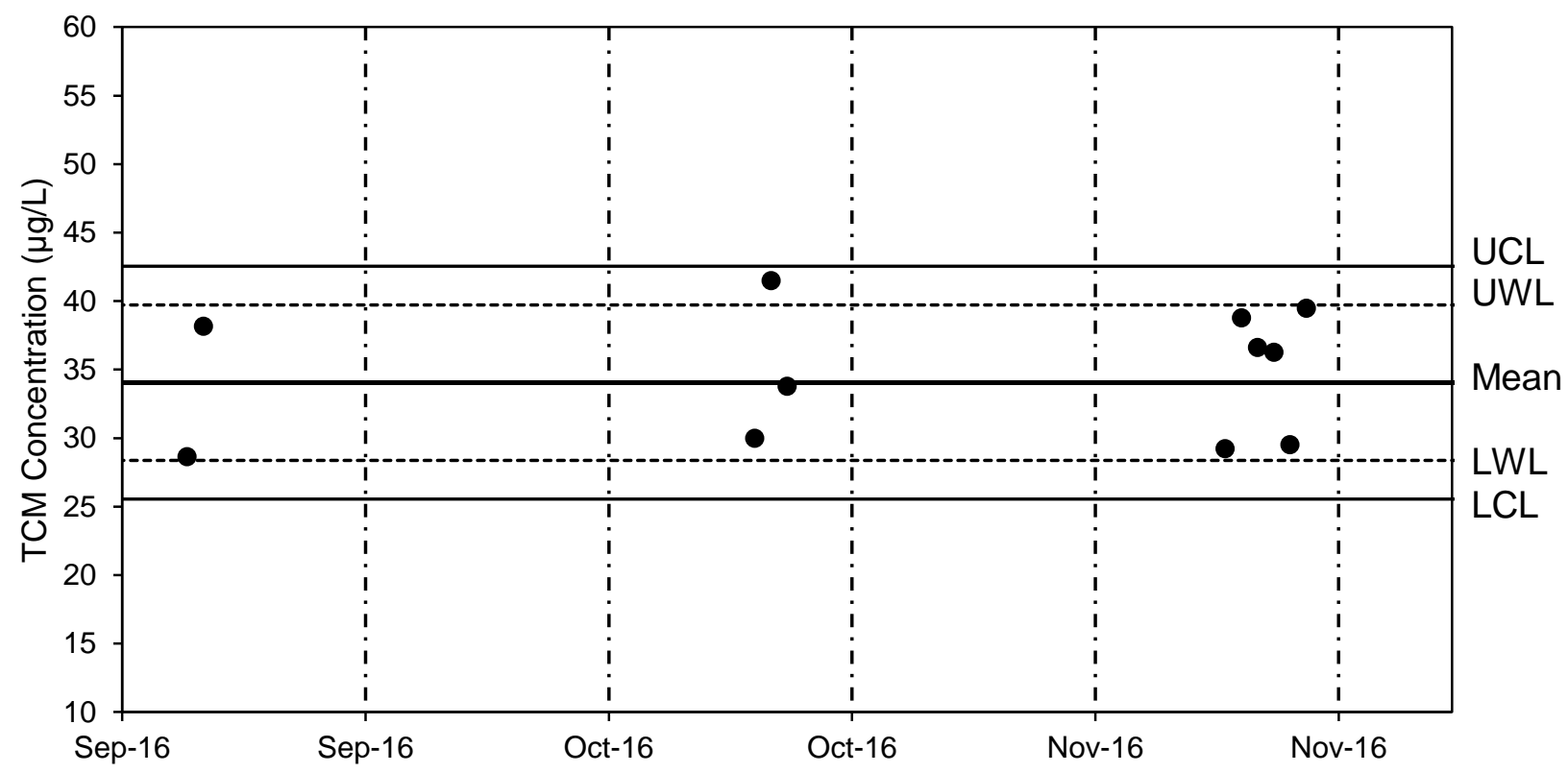

Figure 7-7: Quality Control Chart for TCM

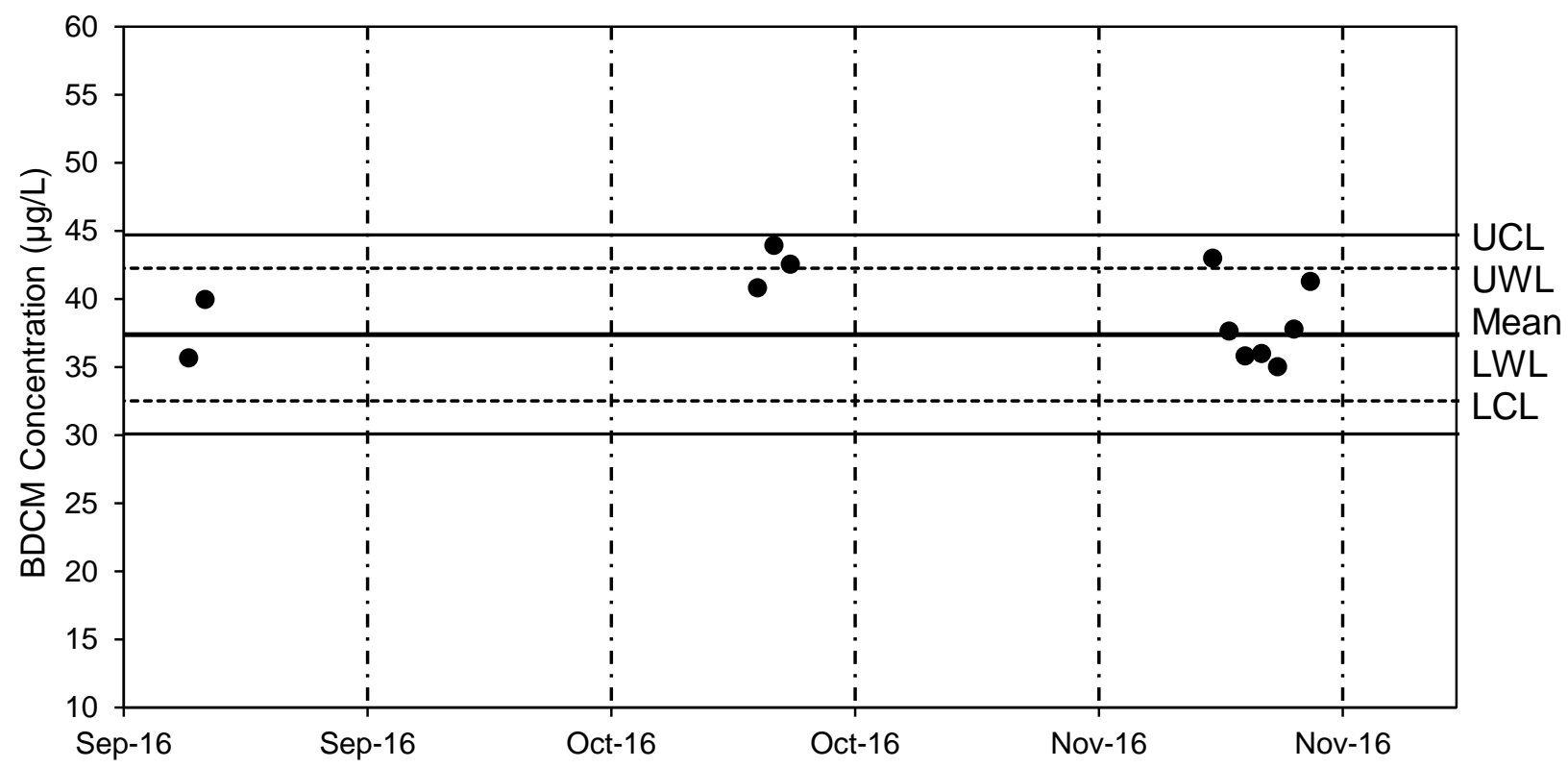

Figure 7-8: Quality Control Chart for BDCM 


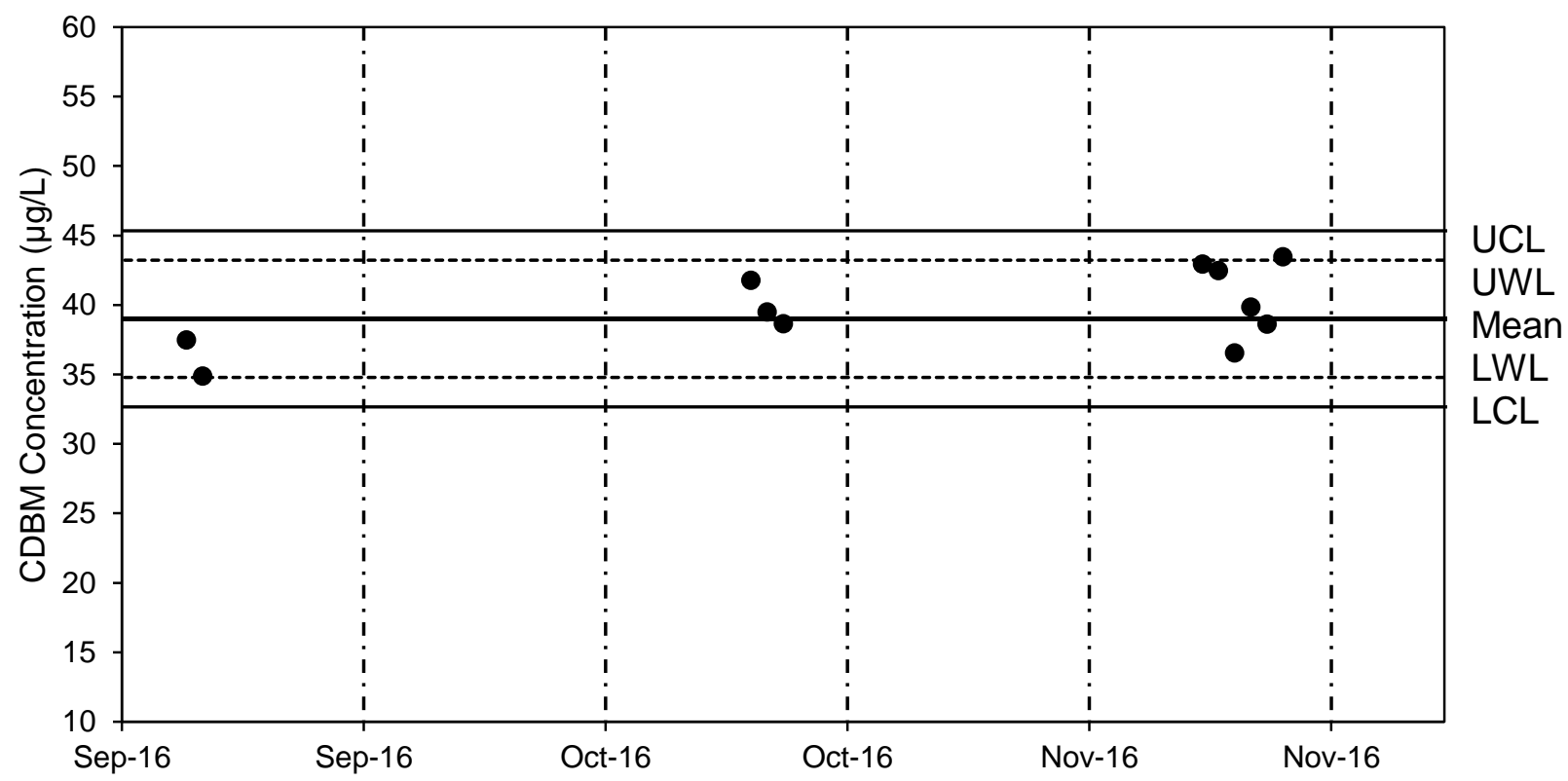

Figure 7-9: Quality Control Chart for CDBM

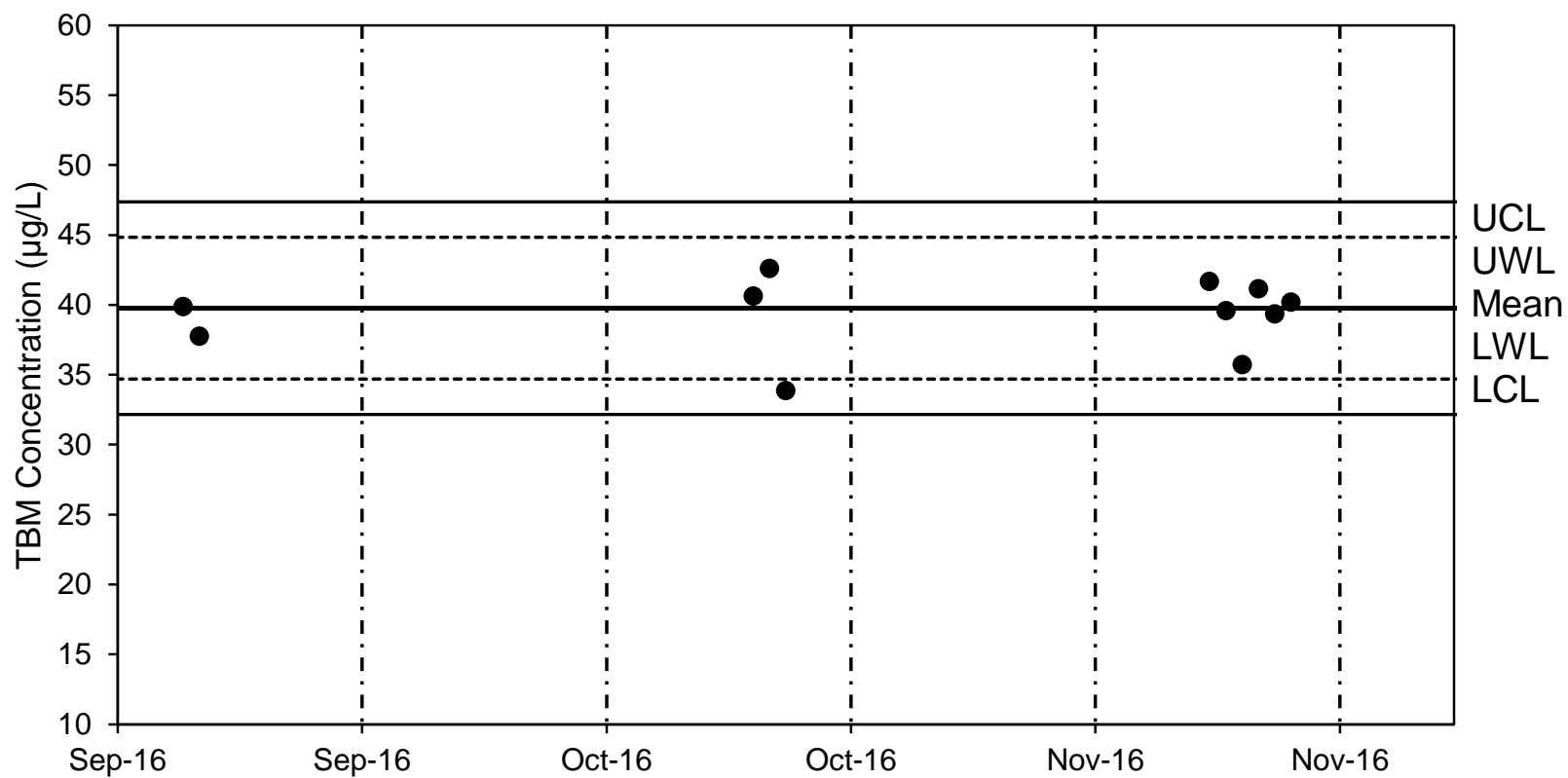

Figure 7-10: Quality Control Chart for TBM 


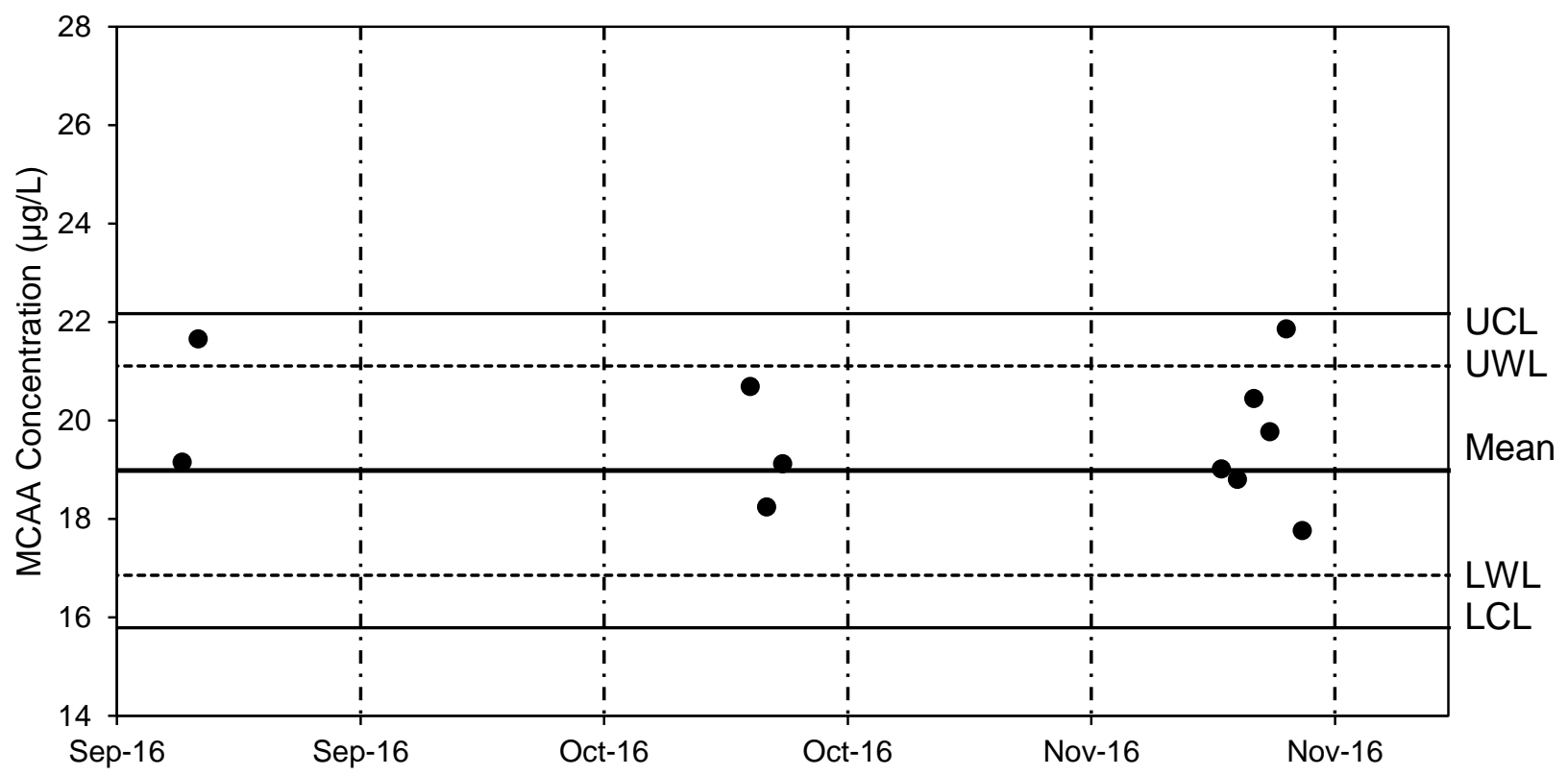

Figure 7-7: Quality Control Chart for MCAA

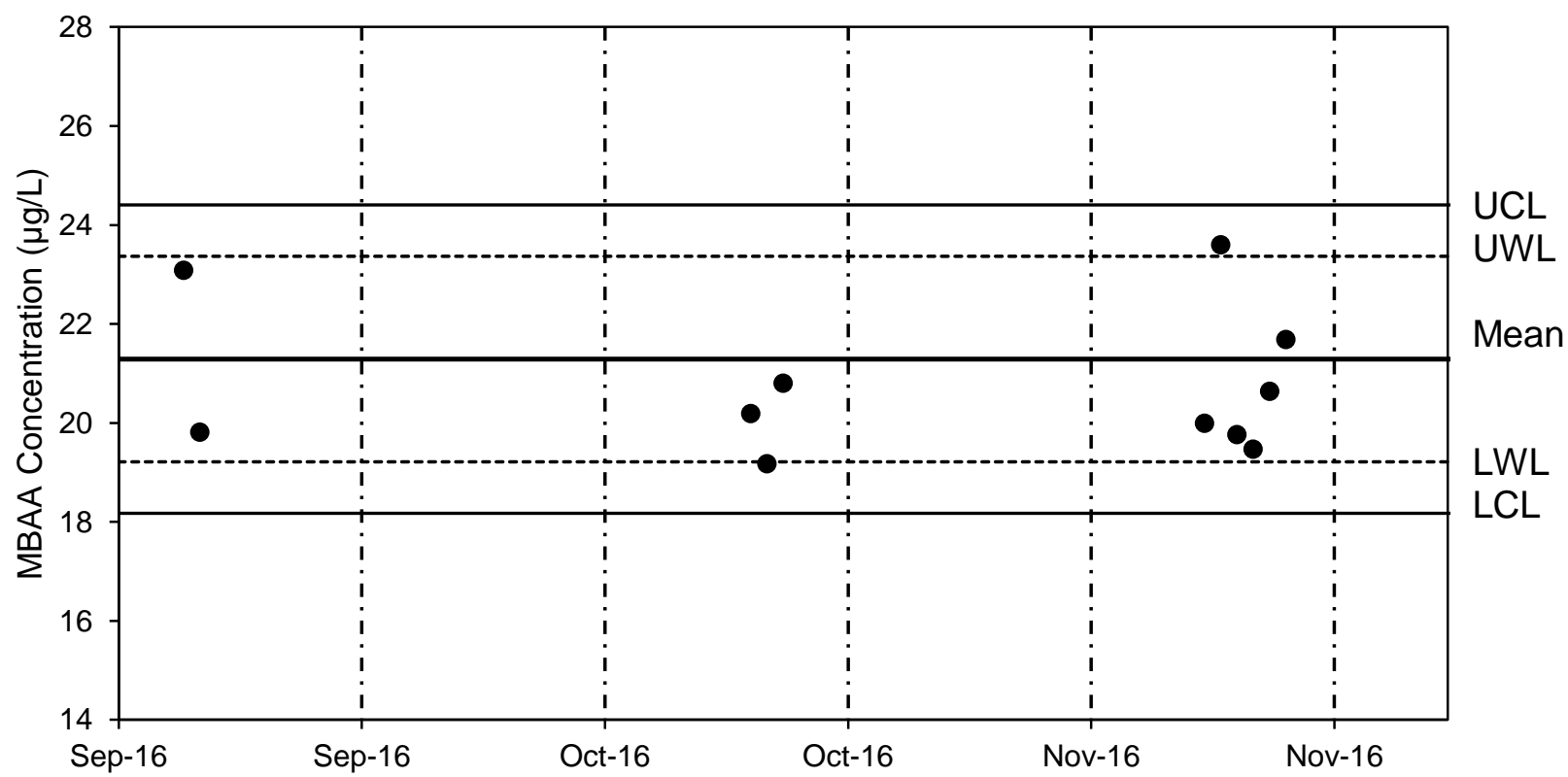

Figure 7-11: Quality Control Chart for MBAA 


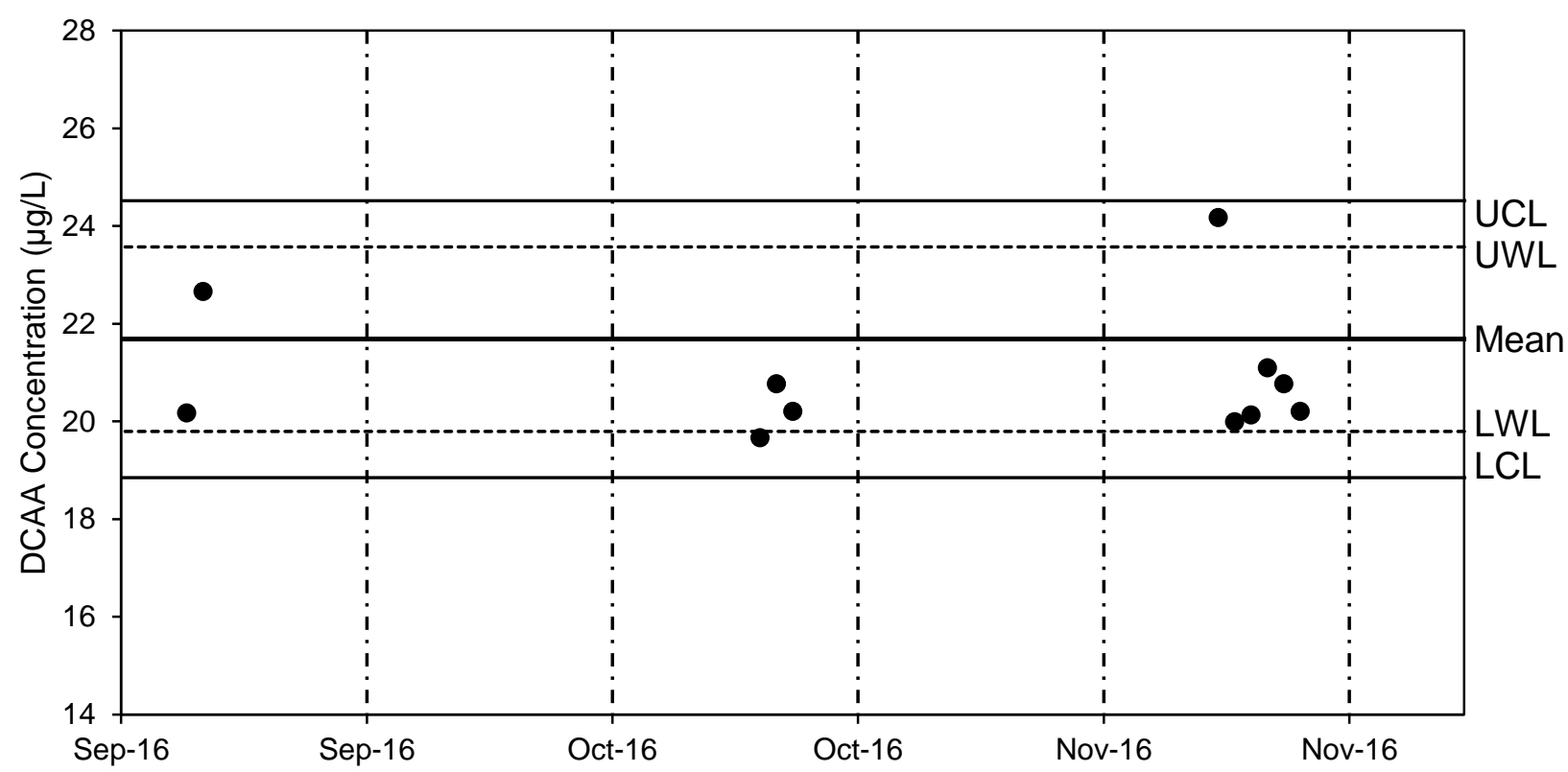

Figure 7-12: Quality Control Chart for DCAA

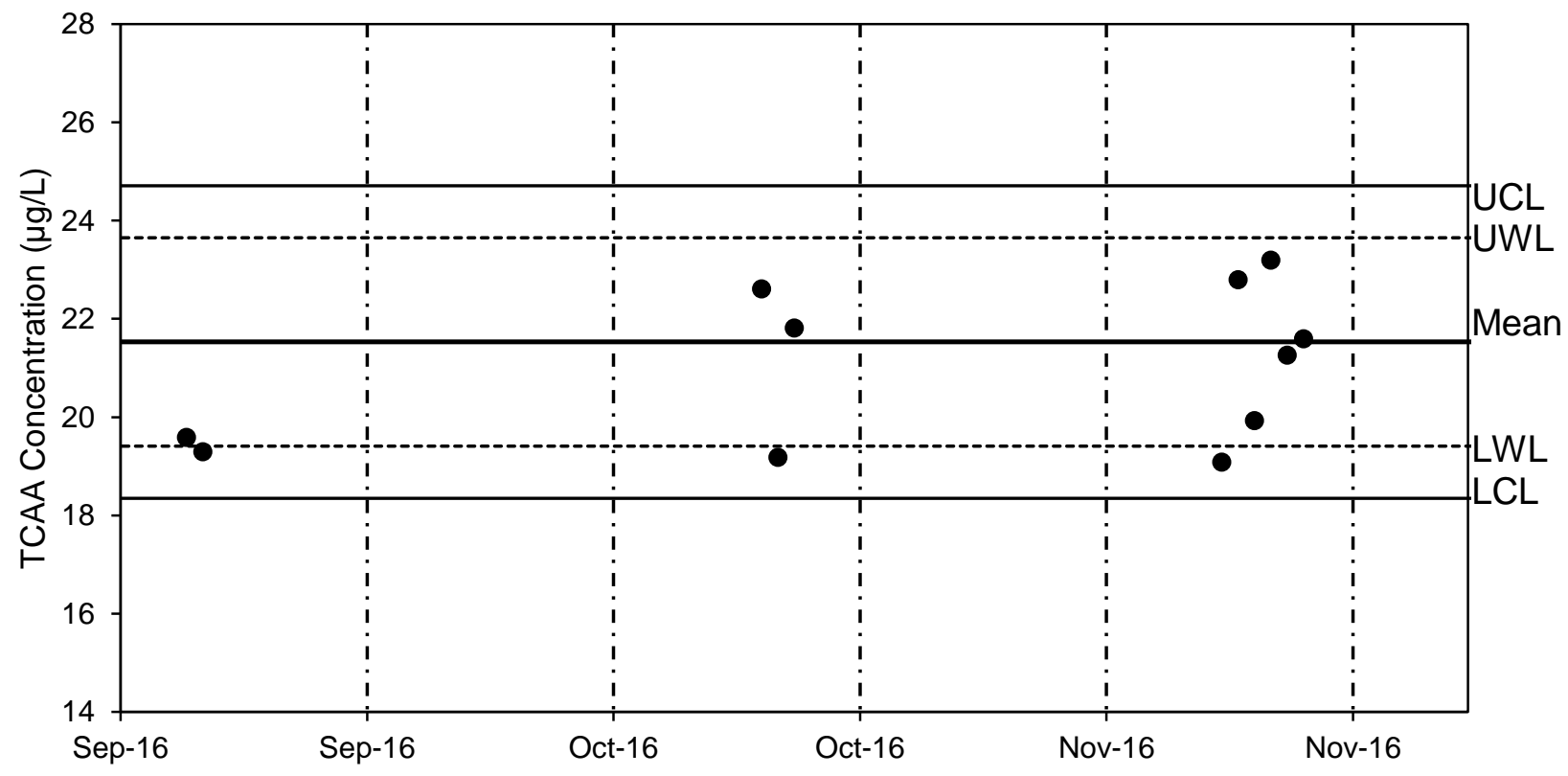

Figure 7-13: Quality Control Chart for TCAA 


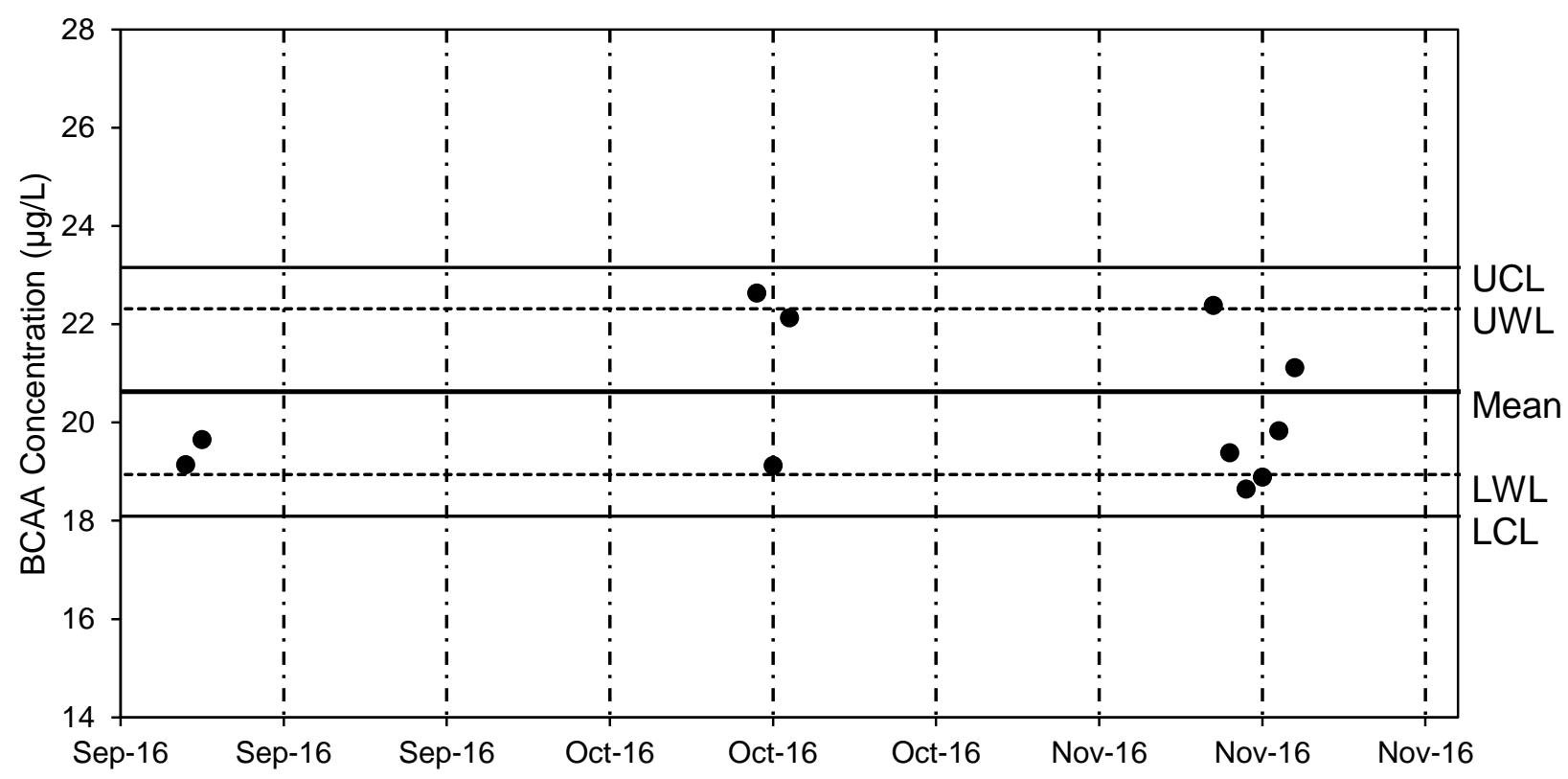

Figure 7-14: Quality Control Chart for BCAA

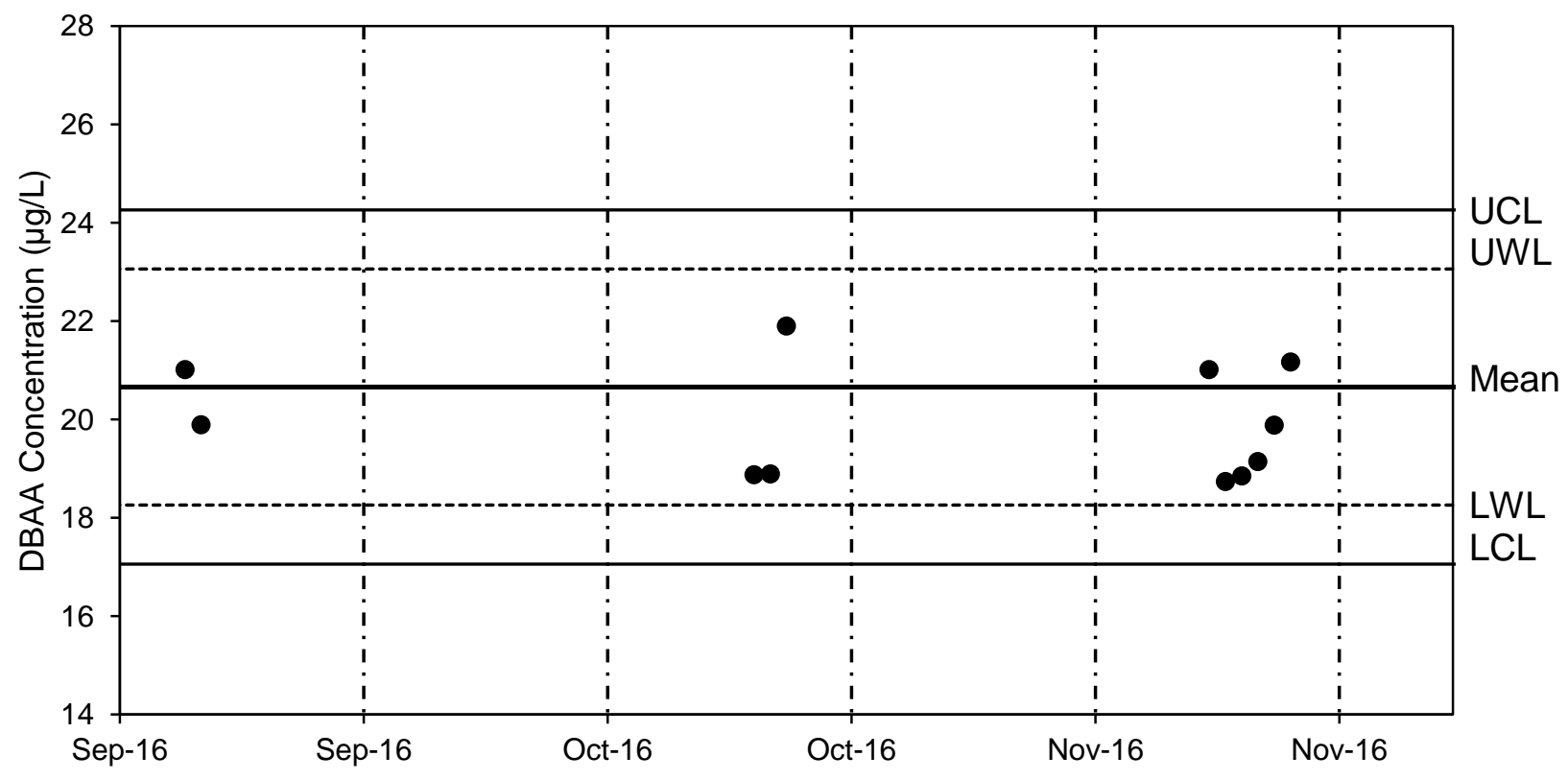

Figure 7-15: Quality Control Chart for DBAA 


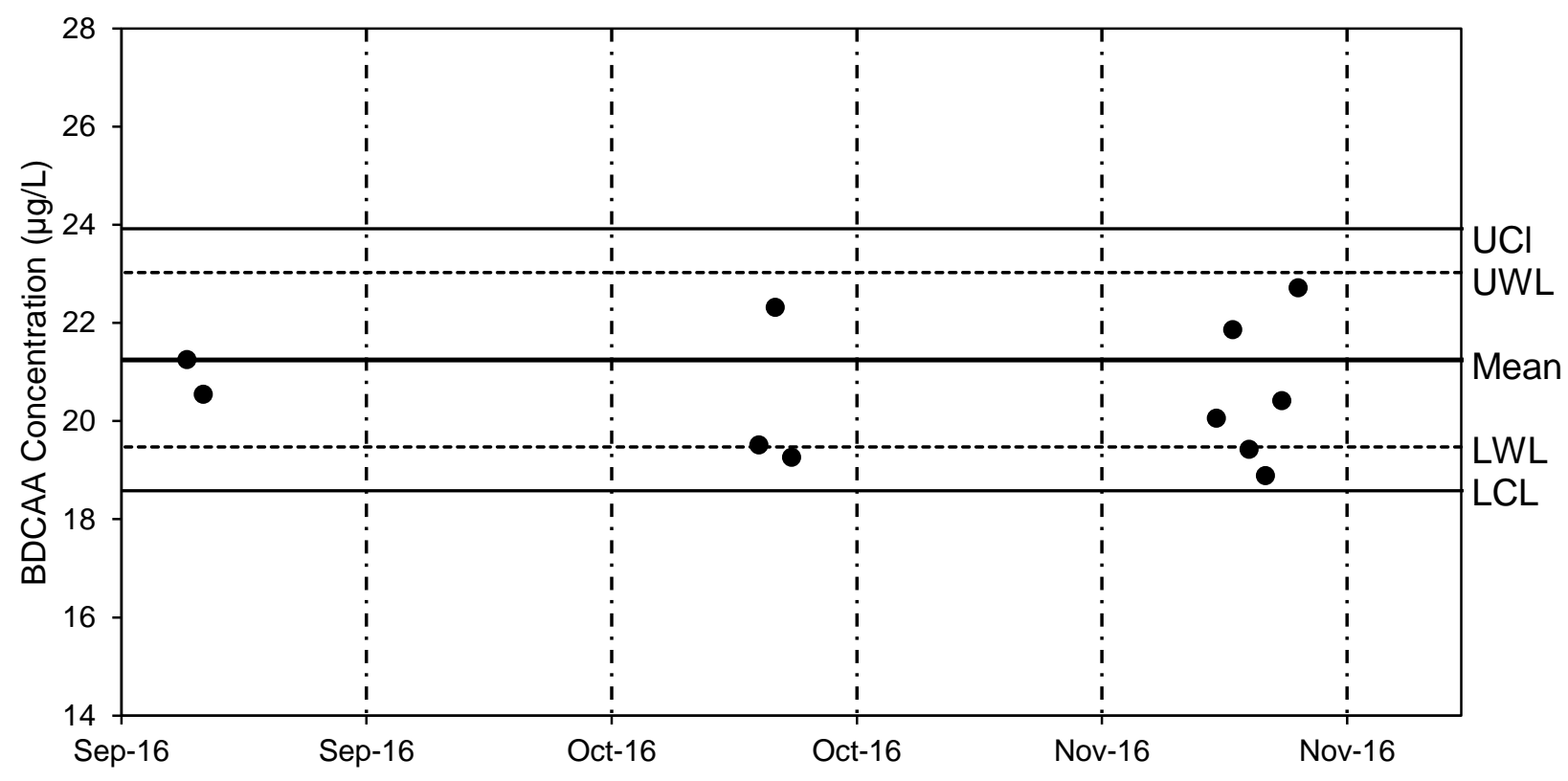

Figure 7-16: Quality Control Chart for BDCAA

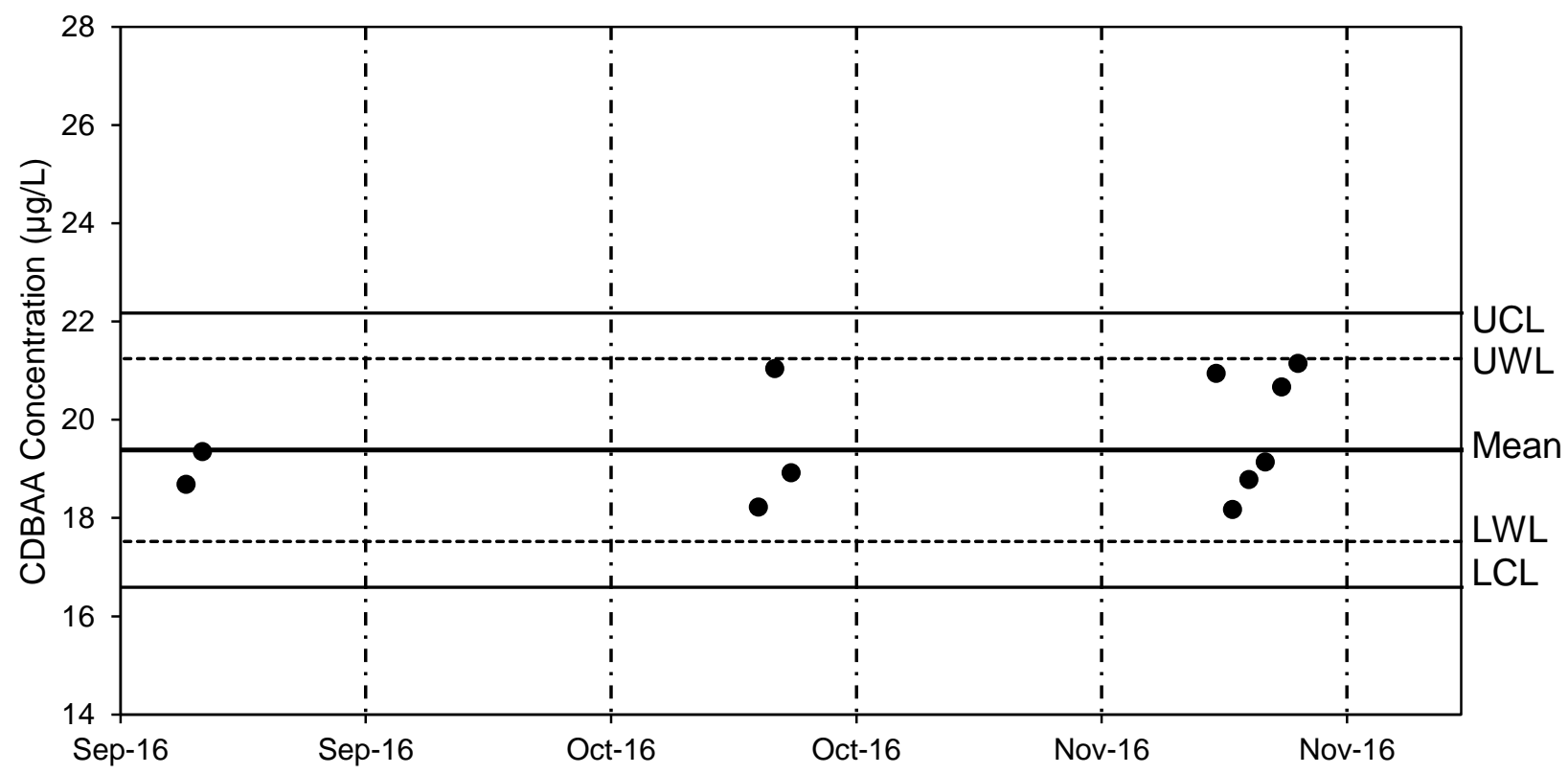

Figure 7-17: Quality Control Chart for CDBAA 


\subsection{Raw Data}

Table 7-6: Raw Data

\begin{tabular}{|c|c|c|c|c|c|c|c|c|c|c|c|c|}
\hline Analyte & Condition & Date & Raw & Settled & $\mathrm{O} 3$ & AOP & CAF & $\mathrm{BAF}$ & BAF & $\begin{array}{l}\text { BAC } \\
\text { Control }\end{array}$ & $\mathrm{BAC}$ & BAC \\
\hline \multirow{9}{*}{$\begin{array}{c}\text { ATP } \\
\text { (ng/g } \\
\text { media) }\end{array}$} & \multirow{5}{*}{ Acclimation } & 11-Мay-16 & N/A & N/A & N/A & N/A & 22 & 336 & 336 & 459 & 266 & 334 \\
\hline & & 11-Jun-16 & N/A & N/A & N/A & N/A & 36 & 287 & 257 & 363 & 280 & 281 \\
\hline & & 04-Jul-16 & N/A & N/A & N/A & N/A & 31 & 370 & 316 & 699 & 338 & 345 \\
\hline & & 04-Aug-16 & N/A & N/A & N/A & N/A & 54 & 392 & 221 & 765 & 252 & 293 \\
\hline & & 17-Aug-16 & N/A & N/A & N/A & N/A & 51 & 264 & 307 & 749 & 344 & 345 \\
\hline & 1 & 14-Sep-16 & N/A & N/A & N/A & N/A & 52 & 428 & 249 & 533 & 240 & 250 \\
\hline & 2 & 20-Oct-16 & N/A & N/A & N/A & N/A & 97 & 444 & 384 & 340 & 479 & 405 \\
\hline & 3 & 14-Nov-16 & N/A & N/A & N/A & N/A & 89 & 307 & 347 & 346 & 326 & 204 \\
\hline & 4 & 05-Dec-16 & N/A & N/A & N/A & N/A & 93 & 394 & 328 & 151 & 140 & 153 \\
\hline \multirow{9}{*}{$\mathrm{pH}$} & \multirow{2}{*}{1} & 29-Aug-16 & 8.15 & 7.18 & N/A & N/A & 7.7 & 7.71 & 7.18 & 7.16 & 7.17 & 7.23 \\
\hline & & 14-Sep-16 & 8.1 & 7.35 & N/A & N/A & 7.72 & 7.57 & 7.23 & 7.15 & 7.14 & 7.24 \\
\hline & \multirow{3}{*}{2} & $3-$ Oct-16 & 8.18 & 7.17 & 7.31 & 7.28 & 7.45 & 7.37 & 7.2 & 7.15 & 7.15 & 7.23 \\
\hline & & 7-Oct-16 & 7.78 & 7.27 & 7.15 & 7.16 & 7.62 & 7.34 & 7.15 & 7.12 & 7.09 & 7.17 \\
\hline & & 14-Oct-16 & 8.05 & 7.31 & 7.52 & 7.33 & 7.63 & 7.42 & 7.18 & 7.19 & 7.05 & 7.11 \\
\hline & \multirow{3}{*}{3} & 20-Oct-16 & 7.96 & 7.33 & 7.35 & 7.32 & 7.52 & 7.36 & 7.1 & 7.15 & 7.1 & 7.12 \\
\hline & & 28-Oct-16 & 8.1 & 7.17 & 7.38 & 7.2 & 7.47 & 7.47 & 7.09 & 7.18 & 7.07 & 7.14 \\
\hline & & 15-Nov-16 & 8.04 & 7.28 & 7.36 & 7.19 & 7.53 & 7.38 & 7.07 & 7.14 & 7.08 & 7.08 \\
\hline & 4 & 16-Nov-16 & 8.1 & 7.23 & 7.33 & 7.24 & 7.45 & 7.36 & 7.1 & 7.15 & 7.1 & 7.1 \\
\hline
\end{tabular}


Table 7-6: Raw Data (Cont.)

\begin{tabular}{|c|c|c|c|c|c|c|c|c|c|c|c|c|}
\hline Analyte & Condition & Date & Raw & Settled & $\mathrm{O} 3$ & AOP & $\mathrm{CAF}$ & BAF & $\mathrm{BAF}$ & $\begin{array}{c}\text { BAC } \\
\text { Control }\end{array}$ & $\mathrm{BAC}$ & $\mathrm{BAC}$ \\
\hline \multirow{9}{*}{$\begin{array}{l}\text { Turbidity } \\
\text { (NTU) }\end{array}$} & \multirow{2}{*}{1} & 29-Aug-16 & 0.575 & 0.166 & N/A & N/A & 0.088 & 0.085 & 0.081 & 0.082 & 0.078 & 0.092 \\
\hline & & 14-Sep-16 & 0.774 & 0.184 & N/A & N/A & 0.085 & 0.083 & 0.081 & 0.087 & 0.074 & 0.09 \\
\hline & \multirow{3}{*}{2} & $3-O c t-16$ & 0.586 & 0.104 & 0.188 & 0.178 & 0.048 & 0.062 & 0.075 & 0.072 & 0.075 & 0.082 \\
\hline & & 7-Oct-16 & 0.598 & 0.114 & 0.185 & 0.168 & 0.076 & 0.084 & 0.092 & 0.075 & 0.078 & 0.08 \\
\hline & & 14-Oct-16 & 0.5 & 0.127 & 0.135 & 0.148 & 0.076 & 0.082 & 0.087 & 0.076 & 0.07 & 0.073 \\
\hline & \multirow{3}{*}{3} & 20 -Oct-16 & 0.58 & 0.14 & 0.13 & 0.124 & 0.041 & 0.049 & 0.078 & 0.075 & 0.077 & 0.069 \\
\hline & & 28-Oct-16 & 0.405 & 0.103 & 0.151 & 0.17 & 0.038 & 0.06 & 0.071 & 0.074 & 0.078 & 0.078 \\
\hline & & 15-Nov-16 & 0.368 & 0.154 & 0.123 & 0.132 & 0.065 & 0.047 & 0.065 & 0.059 & 0.079 & 0.068 \\
\hline & 4 & 16-Nov-16 & 0.395 & 0.155 & 0.134 & 0.132 & 0.056 & 0.055 & 0.068 & 0.064 & 0.078 & 0.07 \\
\hline \multirow{11}{*}{$\begin{array}{l}\mathrm{UV}_{254} \\
\left(\mathrm{~cm}^{-1}\right)\end{array}$} & \multirow{2}{*}{1} & 29-Aug-16 & 0.121 & 0.054 & N/A & N/A & 0.050 & 0.047 & 0.047 & 0.047 & 0.044 & 0.044 \\
\hline & & 14-Sep-16 & 0.110 & 0.061 & N/A & N/A & 0.050 & 0.048 & 0.048 & 0.044 & 0.044 & 0.046 \\
\hline & \multirow{3}{*}{2} & 3 -Oct-16 & 0.110 & 0.057 & 0.054 & 0.048 & 0.040 & 0.035 & 0.035 & 0.049 & 0.034 & 0.034 \\
\hline & & 7-Oct-16 & 0.122 & 0.061 & 0.035 & 0.037 & 0.036 & 0.031 & 0.033 & 0.051 & 0.032 & 0.031 \\
\hline & & 14-Oct-16 & 0.114 & 0.052 & 0.032 & 0.043 & 0.033 & 0.030 & 0.027 & 0.047 & 0.030 & 0.027 \\
\hline & \multirow{4}{*}{3} & $20-O c t-16$ & 0.124 & 0.057 & 0.039 & 0.036 & 0.037 & 0.033 & 0.033 & 0.050 & 0.031 & 0.035 \\
\hline & & 26-Oct-16 & 0.120 & 0.057 & 0.040 & 0.043 & 0.037 & 0.033 & 0.034 & 0.051 & 0.034 & 0.033 \\
\hline & & 28-Oct-16 & 0.121 & 0.055 & 0.041 & 0.043 & 0.040 & 0.037 & 0.036 & 0.048 & 0.035 & 0.036 \\
\hline & & 15-Nov-16 & 0.119 & 0.053 & 0.033 & 0.035 & 0.036 & 0.034 & 0.032 & 0.049 & 0.033 & 0.030 \\
\hline & \multirow{2}{*}{ 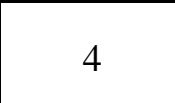 } & 16-Nov-16 & 0.108 & 0.053 & 0.038 & 0.036 & 0.033 & 0.031 & 0.023 & 0.041 & 0.024 & 0.023 \\
\hline & & 3-Dec-16 & 0.118 & 0.057 & 0.041 & 0.048 & 0.037 & 0.031 & 0.032 & 0.051 & 0.031 & 0.031 \\
\hline
\end{tabular}


Table 7-6: Raw Data (Cont.)

\begin{tabular}{|c|c|c|c|c|c|c|c|c|c|c|c|c|}
\hline Analyte & Condition & Date & Raw & Settled & $\mathrm{O} 3$ & $\mathrm{AOP}$ & CAF & BAF & BAF & $\begin{array}{l}\text { BAC } \\
\text { Control }\end{array}$ & BAC & BAC \\
\hline \multirow{11}{*}{$\begin{array}{c}\mathrm{DOC} \\
(\mathrm{mg} / \mathrm{L})\end{array}$} & \multirow{2}{*}{1} & 29-Aug-16 & 5.29 & 3.64 & N/A & N/A & 3.64 & 3.63 & 3.50 & 3.48 & 3.44 & 3.44 \\
\hline & & 14-Sep-16 & 5.03 & 3.29 & N/A & N/A & 3.30 & 3.19 & 3.20 & 3.05 & 3.11 & 3.11 \\
\hline & \multirow{3}{*}{2} & 3 -Oct-16 & 5.42 & 3.58 & 3.41 & 3.42 & 3.50 & 3.22 & 3.32 & 3.41 & 3.15 & 3.17 \\
\hline & & 7-Oct-16 & 5.22 & 3.45 & 3.22 & 3.33 & 3.27 & 3.00 & 3.07 & 3.21 & 2.95 & 2.92 \\
\hline & & $14-O c t-16$ & 5.29 & 3.29 & 3.19 & 3.17 & 3.13 & 3.03 & 3.03 & 3.15 & 3.02 & 2.94 \\
\hline & \multirow{4}{*}{3} & 20 -Oct-16 & 4.99 & 3.12 & 3.17 & 3.25 & 3.05 & 2.90 & 2.86 & 3.06 & 2.87 & 2.95 \\
\hline & & 26-Oct-16 & 5.40 & 3.39 & 3.15 & 3.14 & 3.09 & 2.95 & 3.11 & 3.16 & 3.00 & 3.03 \\
\hline & & 28 -Oct-16 & 5.21 & 3.37 & 3.21 & 3.22 & 3.09 & 2.96 & 3.01 & 3.13 & 2.99 & 3.03 \\
\hline & & 15-Nov-16 & 5.23 & 3.59 & 3.32 & 3.27 & 3.14 & 3.02 & 3.07 & 3.18 & 3.09 & 3.11 \\
\hline & \multirow{2}{*}{4} & 16-Nov-16 & 5.23 & 3.43 & 3.38 & 3.54 & 3.29 & 3.16 & 3.16 & 3.25 & 3.20 & 3.19 \\
\hline & & 3-Dec-16 & 4.79 & 2.92 & 2.79 & 2.96 & 2.65 & 2.70 & 2.74 & 2.87 & 2.67 & 2.71 \\
\hline \multirow{11}{*}{$\begin{array}{c}\text { SUVA } \\
\text { (L/mg- } \\
\mathrm{cm})\end{array}$} & \multirow{2}{*}{1} & 29-Aug-16 & 2.29 & 1.48 & N/A & N/A & 1.37 & 1.29 & 1.34 & 1.35 & 1.28 & 1.28 \\
\hline & & 14-Sep-16 & 2.19 & 1.86 & N/A & N/A & 1.51 & 1.50 & 1.50 & 1.44 & 1.42 & 1.48 \\
\hline & \multirow{3}{*}{2} & 3 -Oct-16 & 2.03 & 1.59 & 1.58 & 1.41 & 1.14 & 1.09 & 1.05 & 1.44 & 1.08 & 1.07 \\
\hline & & 7-Oct-16 & 2.34 & 1.77 & 1.09 & 1.11 & 1.10 & 1.03 & 1.07 & 1.59 & 1.09 & 1.06 \\
\hline & & $14-O c t-16$ & 2.15 & 1.58 & 1.00 & 1.35 & 1.05 & 0.99 & 0.89 & 1.49 & 0.99 & 0.92 \\
\hline & \multirow{4}{*}{3} & 20 -Oct-16 & 2.48 & 1.83 & 1.23 & 1.11 & 1.20 & 1.14 & 1.15 & 1.63 & 1.08 & 1.19 \\
\hline & & 26-Oct-16 & 2.22 & 1.68 & 1.28 & 1.36 & 1.20 & 1.12 & 1.09 & 1.61 & 1.15 & 1.10 \\
\hline & & 28 -Oct-16 & 2.32 & 1.63 & 1.28 & 1.34 & 1.29 & 1.26 & 1.20 & 1.53 & 1.17 & 1.19 \\
\hline & & 15-Nov-16 & 2.06 & 1.48 & 0.99 & 1.07 & 1.15 & 1.13 & 1.04 & 1.54 & 1.07 & 0.96 \\
\hline & \multirow{2}{*}{4} & 16-Nov-16 & 2.06 & 1.55 & 1.12 & 1.02 & 1.00 & 0.98 & 0.73 & 1.26 & 0.75 & 0.72 \\
\hline & & 3-Dec-16 & 2.46 & 1.95 & 1.47 & 1.62 & 1.38 & 1.15 & 1.16 & 1.78 & 1.16 & 1.13 \\
\hline
\end{tabular}


Table 7-6: Raw Data (Cont.)

\begin{tabular}{|c|c|c|c|c|c|c|c|c|c|c|c|c|}
\hline Analyte & Condition & Date & Raw & Settled & $\mathrm{O} 3$ & $\mathrm{AOP}$ & CAF & BAF & BAF & $\begin{array}{l}\text { BAC } \\
\text { Control }\end{array}$ & BAC & BAC \\
\hline \multirow{12}{*}{$\begin{array}{c}\text { Geosmin } \\
\text { Influent } \\
(\mathrm{ng} / \mathrm{L})\end{array}$} & \multirow{3}{*}{1} & 14-Sep-16 & 25.50 & 24.70 & N/A & N/A & 97.30 & 96.8 & 92.3 & 100.4 & 99.2 & 78.9 \\
\hline & & 14-Sep-16 & 19.20 & 18.20 & N/A & N/A & 82.60 & 97.7 & 84.7 & 82.4 & 91.1 & 88.2 \\
\hline & & 14-Sep-16 & 25.70 & 20.10 & N/A & N/A & 90.00 & 91.4 & 86.0 & 78.3 & 85.2 & $\mathrm{~N} / \mathrm{S}$ \\
\hline & \multirow{3}{*}{2} & 13 -Oct-16 & 29.8 & 24.4 & 130.8 & 125.8 & 28.4 & 32.0 & 19.0 & 109.3 & 32.3 & 23.2 \\
\hline & & 13 -Oct-16 & 29.4 & 26.8 & 124.9 & 128.8 & 29.8 & 31.2 & 22.8 & 105.9 & 31.4 & 22.6 \\
\hline & & 13-Oct-16 & 29.4 & 26.8 & 127.9 & 127.3 & 26.7 & 27.3 & 18.6 & 102.4 & 24.6 & 19.2 \\
\hline & \multirow{3}{*}{3} & 14-Nov-16 & 17.1 & 16.4 & 96.9 & 105.4 & 47.1 & 46.5 & 24.1 & 75.4 & 44.5 & 39.8 \\
\hline & & 14-Nov-16 & 17.1 & 16.4 & 103.8 & 103.1 & 51.3 & 53.1 & 35.0 & 49.1 & 43.2 & 31.4 \\
\hline & & 14-Nov-16 & 17.1 & 16.4 & 100.3 & 104.2 & 49.2 & 49.8 & 29.6 & 62.2 & 43.9 & 35.6 \\
\hline & \multirow{3}{*}{4} & 16-Nov-16 & 16.8 & 16.3 & 83.9 & 83.4 & 43.4 & 43.8 & 34.9 & 100.3 & 43.8 & 34.9 \\
\hline & & 16-Nov-16 & 16.8 & 16.3 & 88.5 & 93.3 & 43.4 & 43.1 & 34.9 & 106.0 & 43.1 & 34.9 \\
\hline & & 16-Nov-16 & 16.8 & 16.3 & 120.0 & 122.2 & 43.4 & 43.1 & 34.9 & 106.0 & 43.1 & 34.9 \\
\hline \multirow{12}{*}{$\begin{array}{l}\text { Geosmin } \\
\text { Effluent } \\
(\mathrm{ng} / \mathrm{L})\end{array}$} & \multirow{3}{*}{1} & 14-Sep-16 & N/A & N/A & N/A & N/A & 81.1 & 8.0 & 12.4 & 5.6 & 5.8 & 13.8 \\
\hline & & 14-Sep-16 & N/A & N/A & N/A & N/A & 70.1 & 20.0 & 35.3 & 13.9 & 19.4 & 12.7 \\
\hline & & 14-Sep-16 & N/A & N/A & N/A & N/A & 75.6 & 23.1 & 27.9 & 14.2 & 19.2 & 12.7 \\
\hline & \multirow{3}{*}{2} & 13 -Oct-16 & N/A & N/A & 37.1 & 37.2 & 28.1 & BDL & BDL & 6.5 & BDL & BDL \\
\hline & & 13 -Oct-16 & N/A & N/A & 40.2 & 29.3 & 26.7 & 5.4 & $\mathrm{BDL}$ & 7.7 & BDL & BDL \\
\hline & & 13 -Oct-16 & N/A & N/A & 38.6 & 33.2 & 14.8 & BDL & BDL & 8.3 & BDL & BDL \\
\hline & \multirow{3}{*}{3} & 14-Nov-16 & N/A & N/A & 56.7 & 37.0 & 43.9 & 12.7 & BDL & 10.3 & 8.8 & BDL \\
\hline & & 14-Nov-16 & N/A & N/A & 59.1 & 39.1 & 45.9 & 14.1 & BDL & 13.7 & 9.7 & BDL \\
\hline & & 14-Nov-16 & N/A & N/A & 48.1 & 38.0 & 43.0 & 15.8 & $\mathrm{BDL}$ & 11.8 & 8.9 & $\mathrm{BDL}$ \\
\hline & \multirow{3}{*}{4} & 16-Nov-16 & N/A & N/A & 46.2 & 35.6 & 29.5 & 16.7 & 11.0 & 25.0 & 14.8 & 13.9 \\
\hline & & 16-Nov-16 & N/A & N/A & 41.4 & 36.2 & 29.5 & 16.0 & 11.5 & 24.3 & 16.0 & 11.4 \\
\hline & & 16-Nov-16 & N/A & N/A & 41.4 & 32.9 & 29.5 & 16.0 & 11.5 & 23.7 & 17.3 & 11.4 \\
\hline
\end{tabular}


Table 7-6: Raw Data (Cont.)

\begin{tabular}{|c|c|c|c|c|c|c|c|c|c|c|c|c|}
\hline Analyte & Condition & Date & Raw & Settled & $\mathrm{O} 3$ & $\mathrm{AOP}$ & CAF & BAF & BAF & $\begin{array}{l}\text { BAC } \\
\text { Control }\end{array}$ & BAC & BAC \\
\hline \multirow{12}{*}{$\begin{array}{c}\text { MIB } \\
\text { Influent } \\
\text { (ng/L) }\end{array}$} & \multirow{3}{*}{1} & 14-Sep-16 & 21.4 & 22.0 & N/A & N/A & 97.9 & 101.1 & 91.0 & 85.3 & 89.4 & 98.8 \\
\hline & & 14-Sep-16 & 27.1 & 23.2 & N/A & N/A & 96.2 & 97.8 & 101.8 & 98.1 & 85.4 & 98.8 \\
\hline & & 14-Sep-16 & 15.2 & 14.9 & N/A & N/A & 98.9 & 101.4 & 103.8 & 101.4 & 104.2 & 98.8 \\
\hline & \multirow{3}{*}{2} & 13 -Oct-16 & 12.1 & 11.4 & 102.2 & 104.3 & 45.1 & 36.8 & 30.4 & 114.6 & 41.0 & 31.3 \\
\hline & & 13 -Oct-16 & 13.9 & 10.9 & 104.3 & 105.4 & 44.8 & 35.8 & 29.7 & 121.6 & 38.8 & 32.8 \\
\hline & & 13-Oct-16 & 13.9 & 10.9 & 103.3 & 104.8 & 39.5 & 31.7 & 29.9 & 104.1 & 34.5 & 19.9 \\
\hline & \multirow{3}{*}{3} & 14-Nov-16 & N/A & N/A & 88.8 & 90.0 & 54.3 & 58.9 & 48.1 & 53.8 & 45.1 & 18.4 \\
\hline & & 14-Nov-16 & N/A & N/A & 89.5 & 85.8 & 47.4 & 49.5 & 67.6 & 50.9 & 50.7 & 20.4 \\
\hline & & 14-Nov-16 & N/A & N/A & 89.1 & 87.9 & 50.9 & 54.2 & 57.9 & 47.4 & 47.9 & 17.3 \\
\hline & \multirow{3}{*}{4} & 16-Nov-16 & N/A & N/A & 121.3 & 113.1 & 43.7 & 43.7 & 36.3 & $\mathrm{~N} / \mathrm{S}$ & 43.7 & 36.3 \\
\hline & & 16-Nov-16 & N/A & N/A & 119.1 & 106.4 & 43.7 & 43.7 & 36.3 & $\mathrm{~N} / \mathrm{S}$ & 43.7 & 36.3 \\
\hline & & 16-Nov-16 & N/A & N/A & 116.1 & 106.4 & 43.7 & 43.7 & 36.3 & $\mathrm{~N} / \mathrm{S}$ & 43.7 & 36.3 \\
\hline \multirow{12}{*}{$\begin{array}{c}\text { MIB } \\
\text { Effluent } \\
\text { (ng/L) }\end{array}$} & \multirow{3}{*}{1} & 14-Sep-16 & N/A & N/A & N/A & N/A & 80.5 & 24.1 & 37.5 & 7.3 & 19.7 & 23.4 \\
\hline & & 14-Sep-16 & N/A & N/A & N/A & N/A & 92.9 & 43.7 & 52.9 & 17.0 & 18.0 & 23.4 \\
\hline & & 14-Sep-16 & N/A & N/A & N/A & N/A & 97.1 & 38.8 & 51.7 & 17.2 & 16.7 & 23.4 \\
\hline & \multirow{3}{*}{2} & 13 -Oct-16 & N/A & N/A & 45.6 & 33.9 & 36.1 & 23.8 & 21.4 & 43.7 & 16.4 & 14.1 \\
\hline & & 13 -Oct-16 & N/A & N/A & 44.3 & 36.0 & 36.4 & 24.5 & 25.2 & 38.3 & 15.4 & 13.1 \\
\hline & & 13 -Oct-16 & N/A & N/A & 48.3 & 34.8 & 31.9 & 20.6 & 22.2 & 54.0 & 7.9 & 8.4 \\
\hline & \multirow{3}{*}{3} & 14-Nov-16 & N/A & N/A & 53.0 & 43.5 & 46.1 & 39.2 & 34.3 & 53.8 & 28.5 & 18.4 \\
\hline & & 14-Nov-16 & N/A & N/A & 53.4 & 43.5 & 41.5 & 37.8 & 36.5 & 50.9 & 32.2 & 20.4 \\
\hline & & 14-Nov-16 & N/A & N/A & 53.2 & 43.5 & 46.5 & 34.0 & 29.3 & 47.4 & 26.8 & 17.3 \\
\hline & \multirow{3}{*}{4} & 16-Nov-16 & N/A & N/A & 46.4 & 38.0 & $\mathrm{~N} / \mathrm{S}$ & 34.4 & 25.9 & $\mathrm{~N} / \mathrm{S}$ & 28.6 & 20.6 \\
\hline & & 16-Nov-16 & N/A & N/A & 41.1 & 37.6 & $\mathrm{~N} / \mathrm{S}$ & 32.9 & 29.4 & $\mathrm{~N} / \mathrm{S}$ & 27.6 & 19.3 \\
\hline & & 16-Nov-16 & N/A & N/A & 41.1 & 33.3 & $\mathrm{~N} / \mathrm{S}$ & 32.9 & 29.4 & $\mathrm{~N} / \mathrm{S}$ & 27.6 & 19.3 \\
\hline
\end{tabular}


Table 7-6: Raw Data (Cont.)

\begin{tabular}{|c|c|c|c|c|c|c|c|c|c|c|c|c|}
\hline Analyte & Condition & Date & Raw & Settled & $\mathrm{O} 3$ & AOP & CAF & BAF & BAF & $\begin{array}{c}\text { BAC } \\
\text { Control }\end{array}$ & BAC & $\mathrm{BAC}$ \\
\hline \multirow{8}{*}{$\begin{array}{c}\text { Total } \\
\text { THM } \\
(\mu \mathrm{g} / \mathrm{L})\end{array}$} & \multirow{2}{*}{1} & 14-Sep-16 & 198.0 & 72.7 & $\mathrm{~N} / \mathrm{A}$ & $\mathrm{N} / \mathrm{A}$ & 74.0 & 83.8 & 71.2 & 68.4 & 63.4 & 65.0 \\
\hline & & 14-Sep-16 & 170.8 & 74.2 & N/A & $\mathrm{N} / \mathrm{A}$ & 59.1 & 72.0 & 73.0 & 67.6 & 66.5 & 57.5 \\
\hline & \multirow{2}{*}{2} & & 159.5 & 70.8 & 66.9 & 49.4 & 64.8 & 45.6 & 48.2 & 59.0 & 40.2 & 43.4 \\
\hline & & 13-Oct-16 & 152.7 & 66.5 & 68.6 & 55.4 & 60.1 & 46.1 & 48.2 & 56.2 & 61.4 & 42.1 \\
\hline & \multirow{2}{*}{3} & 14-Nov-16 & 174.6 & 85.5 & 72.5 & 90.3 & 64.1 & 87.7 & 67.9 & 74.0 & 57.9 & 64.4 \\
\hline & & 14-Nov-16 & 194.2 & 85.4 & 67.3 & 81.1 & 79.6 & 83.6 & 73.2 & 72.1 & 49.5 & 55.5 \\
\hline & \multirow{2}{*}{4} & 16-Nov-16 & 174.6 & 85.5 & 87.0 & 62.0 & 61.8 & 63.8 & 62.1 & 66.5 & 62.8 & 72.4 \\
\hline & & 16-Nov-16 & 194.2 & 85.4 & 56.6 & 72.7 & 79.7 & 69.1 & 77.3 & 79.5 & 58.6 & 78.2 \\
\hline \multirow{8}{*}{$\begin{array}{c}\text { TCM } \\
(\mu \mathrm{g} / \mathrm{L})\end{array}$} & \multirow{2}{*}{1} & 14-Sep-16 & 158.1 & 59.0 & $\mathrm{~N} / \mathrm{A}$ & $\mathrm{N} / \mathrm{A}$ & 70.2 & 69.0 & 59.6 & 57.2 & 52.5 & 54.2 \\
\hline & & 14-Sep-16 & 141.5 & 61.0 & N/A & $\mathrm{N} / \mathrm{A}$ & 55.0 & 59.7 & 62.9 & 56.5 & 57.3 & 49.5 \\
\hline & \multirow{2}{*}{2} & 13-Oct-16 & 131.9 & 56.1 & 40.0 & 36.1 & 41.4 & 32.3 & 34.1 & 51.1 & 29.5 & 30.8 \\
\hline & & 13-Oct-16 & 125.4 & 53.0 & 41.2 & 40.1 & 38.5 & 33.2 & 34.1 & 45.3 & 43.7 & 30.2 \\
\hline & \multirow{2}{*}{3} & 14-Nov-16 & 127.9 & 59.9 & 39.8 & 48.7 & 27.5 & 55.8 & 40.1 & 52.0 & 34.3 & 41.2 \\
\hline & & 14-Nov-16 & 145.1 & 58.9 & 38.1 & 45.9 & 37.8 & 47.0 & 44.7 & 51.3 & 29.3 & 32.9 \\
\hline & \multirow{2}{*}{4} & 16-Nov-16 & 127.9 & 59.9 & 57.4 & 36.8 & 36.7 & 38.9 & 42.0 & 46.1 & 39.9 & 46.5 \\
\hline & & 16-Nov-16 & 145.1 & 58.9 & 36.7 & 45.0 & 50.6 & 46.2 & 48.2 & 56.6 & 39.8 & 54.6 \\
\hline \multirow{8}{*}{$\begin{array}{l}\text { BDCM } \\
(\mu \mathrm{g} / \mathrm{L})\end{array}$} & \multirow{2}{*}{1} & 14-Sep-16 & 39.9 & 13.7 & $\mathrm{~N} / \mathrm{A}$ & $\mathrm{N} / \mathrm{A}$ & 3.8 & 14.8 & 11.6 & 11.2 & 10.9 & 10.8 \\
\hline & & 14-Sep-16 & 29.3 & 13.2 & N/A & N/A & 4.0 & 12.3 & 10.2 & 11.1 & 9.2 & 8.0 \\
\hline & \multirow{2}{*}{2} & 13-Oct-16 & 27.6 & 14.8 & 26.5 & 12.8 & 23.0 & 12.9 & 13.7 & 7.9 & 10.3 & 12.1 \\
\hline & & 13-Oct-16 & 27.3 & 13.5 & 27.1 & 14.9 & 21.2 & 12.5 & 17.0 & 10.9 & 17.2 & 11.6 \\
\hline & \multirow{2}{*}{3} & 14-Nov-16 & 46.8 & 25.6 & 32.7 & 37.7 & 32.7 & 27.8 & 23.9 & 21.9 & 19.7 & 19.2 \\
\hline & & 14-Nov-16 & 49.2 & 26.5 & 29.2 & 35.3 & 36.7 & 32.6 & 24.5 & 20.8 & 16.3 & 18.8 \\
\hline & \multirow{2}{*}{4} & 16-Nov-16 & 46.8 & 25.6 & 25.7 & 21.3 & 25.1 & 20.8 & 20.1 & 20.4 & 19.1 & 22.0 \\
\hline & & 16-Nov-16 & 49.2 & 26.5 & 19.9 & 23.8 & 29.1 & 22.9 & 25.2 & 22.9 & 18.7 & 23.6 \\
\hline
\end{tabular}


Table 7-6: Raw Data (Cont.)

\begin{tabular}{|c|c|c|c|c|c|c|c|c|c|c|c|c|}
\hline Analyte & Condition & Date & Raw & Settled & $\mathrm{O} 3$ & $\mathrm{AOP}$ & CAF & $\mathrm{BAF}$ & $\mathrm{BAF}$ & $\begin{array}{c}\text { BAC } \\
\text { Control }\end{array}$ & $\mathrm{BAC}$ & BAC \\
\hline \multirow{8}{*}{$\begin{array}{l}\text { Total } \\
\text { HAA } \\
(\mu \mathrm{g} / \mathrm{L})\end{array}$} & \multirow{2}{*}{1} & 14-Sep-16 & 79.2 & 76.6 & N/A & N/A & 63.9 & 81.3 & 57.6 & 82.9 & 59.7 & 64.9 \\
\hline & & 14-Sep-16 & 107.8 & 72.6 & N/A & N/A & 56.9 & 51.9 & 57.6 & 67.9 & 53.3 & 53.4 \\
\hline & \multirow{2}{*}{2} & 13-Oct-16 & 148.7 & 75.8 & 83.7 & 76.5 & 61.8 & 77.5 & 75.1 & 72.9 & 64.8 & 71.2 \\
\hline & & 13-Oct-16 & 112.7 & 97.9 & 67.0 & 84.1 & 67.0 & 72.8 & 61.1 & 70.3 & 69.1 & 77.6 \\
\hline & \multirow{2}{*}{3} & 14-Nov-16 & 146.9 & 107.2 & 86.8 & 125.9 & 129.8 & 117.3 & 116.5 & 83.4 & 120.3 & 101.3 \\
\hline & & 14-Nov-16 & 166.7 & 104.4 & 109.6 & 110.5 & 132.0 & 93.8 & 103.2 & 111.3 & 121.5 & 106.9 \\
\hline & \multirow{2}{*}{4} & 16-Nov-16 & 146.9 & 107.2 & 98.0 & 77.1 & 104.3 & 99.2 & 120.8 & 133.3 & 95.4 & 89.4 \\
\hline & & 16-Nov-16 & 166.7 & 104.4 & 103.6 & 83.1 & 90.1 & 99.2 & 93.2 & 84.8 & 95.4 & 82.1 \\
\hline \multirow{8}{*}{$\begin{array}{l}\text { MCAA } \\
(\mu \mathrm{g} / \mathrm{L})\end{array}$} & \multirow{2}{*}{1} & 14-Sep-16 & 2.4 & 19.2 & N/A & N/A & 16.8 & 2.8 & 4.2 & 16.5 & 7.3 & 9.5 \\
\hline & & 14-Sep-16 & 6.6 & 18.7 & N/A & N/A & 16.8 & 6.6 & 4.2 & 20.3 & 7.6 & 6.5 \\
\hline & \multirow{2}{*}{2} & 13 -Oct-16 & 37.7 & 17.3 & 24.4 & 27.5 & 9.7 & 34.2 & 21.8 & 24.8 & 15.7 & 32.8 \\
\hline & & 13 -Oct-16 & 23.8 & 18.5 & 19.9 & 24.5 & 25.3 & 31.5 & 13.4 & 21.1 & 23.0 & 27.2 \\
\hline & \multirow{2}{*}{3} & 14-Nov-16 & 19.7 & 29.5 & 22.0 & 47.4 & 13.4 & 59.5 & 57.7 & 22.9 & 61.4 & 38.2 \\
\hline & & 14-Nov-16 & 33.4 & 25.8 & 40.8 & 36.7 & 62.1 & 32.5 & 43.7 & 43.1 & 51.6 & 47.4 \\
\hline & \multirow{2}{*}{4} & 16-Nov-16 & 19.7 & 29.5 & 32.4 & 20.2 & 39.9 & 29.1 & 43.1 & 61.2 & 25.6 & 16.8 \\
\hline & & 16-Nov-16 & 33.4 & 25.8 & 34.6 & 21.0 & 22.6 & 29.1 & 30.6 & 26.2 & 25.6 & 15.3 \\
\hline \multirow{8}{*}{$\begin{array}{l}\text { MBAA } \\
(\mu \mathrm{g} / \mathrm{L})\end{array}$} & \multirow{2}{*}{1} & 14-Sep-16 & 2.2 & 1.9 & N/A & N/A & 2.1 & 2.3 & 2.1 & 2.2 & 1.9 & 2.0 \\
\hline & & 14-Sep-16 & 3.3 & 2.0 & N/A & N/A & 2.1 & 2.3 & 2.1 & 2.2 & 1.9 & 2.0 \\
\hline & \multirow{2}{*}{2} & 13-Oct-16 & 2.3 & 2.6 & 2.6 & 2.0 & 2.7 & 3.4 & 2.6 & 2.8 & 2.6 & 2.4 \\
\hline & & 13-Oct-16 & 2.5 & 2.6 & 2.1 & 2.6 & 2.5 & 2.6 & 2.6 & 3.1 & 2.5 & 2.5 \\
\hline & \multirow{2}{*}{3} & 14-Nov-16 & 2.3 & 2.6 & 2.7 & 2.7 & 5.3 & 3.0 & 2.8 & 2.8 & 3.1 & 2.8 \\
\hline & & 14-Nov-16 & 2.5 & 2.7 & 2.8 & 2.7 & 3.1 & 3.0 & 2.9 & 2.5 & 2.9 & 2.9 \\
\hline & \multirow{2}{*}{4} & 16-Nov-16 & 2.3 & 2.6 & 2.6 & 2.3 & 2.3 & 3.0 & 2.6 & 2.4 & 2.9 & 2.5 \\
\hline & & 16-Nov-16 & 2.5 & 2.7 & 2.6 & 2.3 & 2.7 & 2.6 & 2.1 & 2.3 & 2.6 & 2.3 \\
\hline
\end{tabular}


Table 7-6: Raw Data (Cont.)

\begin{tabular}{|c|c|c|c|c|c|c|c|c|c|c|c|c|}
\hline Analyte & Condition & Date & Raw & Settled & $\mathrm{O} 3$ & $\mathrm{AOP}$ & CAF & BAF & BAF & $\begin{array}{c}\text { BAC } \\
\text { Control }\end{array}$ & BAC & BAC \\
\hline \multirow{8}{*}{$\begin{array}{l}\text { DCAA } \\
(\mu \mathrm{g} / \mathrm{L})\end{array}$} & \multirow{2}{*}{1} & 14-Sep-16 & 30.5 & 21.1 & N/A & N/A & 18.9 & 28.0 & 18.0 & 26.7 & 13.9 & 14.3 \\
\hline & & 14-Sep-16 & 43.5 & 19.5 & N/A & N/A & 16.0 & 15.9 & 18.0 & 18.1 & 14.9 & 15.5 \\
\hline & \multirow{2}{*}{2} & 13 -Oct-16 & 46.7 & 23.3 & 23.4 & 24.3 & 22.5 & 17.4 & 16.7 & 16.9 & 16.5 & 14.2 \\
\hline & & 13 -Oct-16 & 36.7 & 31.3 & 22.7 & 25.6 & 18.6 & 16.4 & 15.9 & 17.7 & 13.9 & 16.5 \\
\hline & \multirow{2}{*}{3} & 14-Nov-16 & 56.3 & 35.5 & 33.2 & 41.5 & 58.1 & 26.4 & 27.4 & 24.4 & 26.1 & 29.7 \\
\hline & & 14-Nov-16 & 59.3 & 33.3 & 35.7 & 38.3 & 32.4 & 28.5 & 27.7 & 26.6 & 32.2 & 27.4 \\
\hline & \multirow{2}{*}{4} & 16-Nov-16 & 56.3 & 35.5 & 33.1 & 29.5 & 30.8 & 31.1 & 37.0 & 30.0 & 31.0 & 32.8 \\
\hline & & 16-Nov-16 & 59.3 & 33.3 & 32.1 & 32.0 & 31.4 & 31.1 & 28.4 & 25.3 & 31.0 & 29.3 \\
\hline \multirow{8}{*}{$\begin{array}{l}\text { TCAA } \\
(\mu \mathrm{g} / \mathrm{L})\end{array}$} & \multirow{2}{*}{1} & 14-Sep-16 & 31.4 & 18.2 & N/A & N/A & 14.8 & 23.6 & 17.2 & 21.0 & 15.3 & 15.1 \\
\hline & & 14-Sep-16 & 38.1 & 16.2 & N/A & N/A & 12.8 & 14.6 & 17.2 & 14.8 & 16.0 & 16.8 \\
\hline & \multirow{2}{*}{2} & 13-Oct-16 & 48.3 & 22.9 & 17.2 & 13.1 & 13.9 & 13.0 & 14.7 & 18.9 & 14.0 & 12.6 \\
\hline & & $13-O c t-16$ & 40.3 & 29.3 & 12.8 & 15.5 & 11.2 & 12.8 & 13.2 & 18.8 & 13.7 & 15.4 \\
\hline & \multirow{2}{*}{3} & 14-Nov-16 & 56.9 & 27.8 & 17.1 & 20.1 & 31.9 & 17.0 & 17.4 & 22.2 & 17.8 & 19.0 \\
\hline & & 14-Nov-16 & 59.7 & 26.1 & 18.4 & 18.7 & 17.8 & 18.3 & 17.4 & 23.3 & 17.9 & 17.6 \\
\hline & \multirow{2}{*}{4} & 16-Nov-16 & 56.9 & 27.8 & 18.2 & 16.3 & 15.2 & $<\mathrm{MDL}$ & 21.0 & 23.8 & $<\mathrm{MDL}$ & 20.4 \\
\hline & & 16-Nov-16 & 59.7 & 26.1 & 18.0 & 16.9 & 16.9 & 19.9 & 16.1 & 20.1 & 19.5 & 18.7 \\
\hline \multirow{8}{*}{$\begin{array}{l}\text { BCAA } \\
(\mu \mathrm{g} / \mathrm{L})\end{array}$} & \multirow{2}{*}{1} & 14-Sep-16 & 3.6 & 3.5 & N/A & N/A & 3.5 & 3.9 & 3.5 & 3.8 & 3.6 & 3.5 \\
\hline & & 14-Sep-16 & 3.7 & 3.5 & N/A & N/A & 3.5 & 3.5 & $<\mathrm{MDL}$ & 3.5 & 3.5 & 3.4 \\
\hline & \multirow{2}{*}{2} & 13 -Oct-16 & 4.0 & 3.6 & 3.8 & 3.6 & 3.5 & 3.5 & 3.6 & 3.5 & 3.5 & 3.6 \\
\hline & & 13 -Oct-16 & 3.7 & 3.9 & 3.7 & 3.7 & 3.4 & 3.5 & 3.5 & 3.5 & 3.6 & 3.7 \\
\hline & \multirow{2}{*}{3} & 14-Nov-16 & 3.4 & 3.6 & 3.5 & 3.6 & 5.1 & 3.2 & 3.3 & 3.2 & 3.3 & 3.3 \\
\hline & & 14-Nov-16 & 3.5 & 3.4 & 3.5 & 3.5 & 3.4 & 3.3 & 3.3 & 3.2 & 3.3 & 3.3 \\
\hline & \multirow{2}{*}{4} & 16-Nov-16 & 3.4 & 3.6 & 3.3 & 3.1 & 3.0 & $<\mathrm{MDL}$ & 3.1 & 3.0 & $<\mathrm{MDL}$ & 3.1 \\
\hline & & 16-Nov-16 & 3.5 & 3.4 & 3.3 & 3.2 & 3.2 & 3.1 & 2.9 & 2.9 & 3.1 & 3.0 \\
\hline
\end{tabular}


Table 7-6: Raw Data (Cont.)

\begin{tabular}{|c|c|c|c|c|c|c|c|c|c|c|c|c|}
\hline Analyte & Condition & Date & Raw & Settled & $\mathrm{O} 3$ & $\mathrm{AOP}$ & $\mathrm{CAF}$ & BAF & BAF & $\begin{array}{l}\text { BAC } \\
\text { Control }\end{array}$ & BAC & BAC \\
\hline \multirow{8}{*}{$\begin{array}{l}\text { DBAA } \\
(\mu \mathrm{g} / \mathrm{L})\end{array}$} & \multirow{2}{*}{1} & 14-Sep-16 & 3.5 & 3.4 & N/A & N/A & $<\mathrm{MDL}$ & 3.6 & 3.5 & 3.6 & $<\mathrm{MDL}$ & 3.4 \\
\hline & & 14-Sep-16 & 3.5 & 3.5 & N/A & N/A & $<\mathrm{MDL}$ & $<\mathrm{MDL}$ & $<\mathrm{MDL}$ & $<\mathrm{MDL}$ & $<\mathrm{MDL}$ & $<\mathrm{MDL}$ \\
\hline & \multirow{2}{*}{2} & 13-Oct-16 & $<\mathrm{MDL}$ & $<\mathrm{MDL}$ & $<\mathrm{MDL}$ & $<\mathrm{MDL}$ & 3.4 & $<\mathrm{MDL}$ & 3.5 & $<\mathrm{MDL}$ & $<\mathrm{MDL}$ & $<\mathrm{MDL}$ \\
\hline & & 13-Oct-16 & $<\mathrm{MDL}$ & $<\mathrm{MDL}$ & $<\mathrm{MDL}$ & $<\mathrm{MDL}$ & $<\mathrm{MDL}$ & $<\mathrm{MDL}$ & $<\mathrm{MDL}$ & $<\mathrm{MDL}$ & $<\mathrm{MDL}$ & $<\mathrm{MDL}$ \\
\hline & \multirow{2}{*}{3} & 14-Nov-16 & 3.4 & 2.8 & 2.8 & $<\mathrm{MDL}$ & 4.2 & 2.8 & 2.7 & 2.8 & 2.7 & 2.8 \\
\hline & & 14-Nov-16 & 3.4 & 2.7 & 2.7 & $<\mathrm{MDL}$ & 2.7 & 2.8 & 2.8 & 2.8 & 2.9 & 2.8 \\
\hline & \multirow{2}{*}{4} & 16-Nov-16 & 3.4 & 2.8 & 2.6 & $<\mathrm{MDL}$ & 2.6 & $<\mathrm{MDL}$ & 2.6 & 2.6 & $<\mathrm{MDL}$ & 2.6 \\
\hline & & 16-Nov-16 & 3.4 & 2.7 & 2.6 & 2.6 & 2.6 & 2.6 & 2.6 & 2.6 & 2.6 & 2.6 \\
\hline \multirow{8}{*}{$\begin{array}{c}\text { BDCAA } \\
(\mu \mathrm{g} / \mathrm{L})\end{array}$} & \multirow{2}{*}{1} & 14-Sep-16 & 9.2 & 9.3 & N/A & N/A & $<\mathrm{MDL}$ & 9.2 & 9.2 & 9.2 & 9.7 & 9.2 \\
\hline & & 14-Sep-16 & 9.2 & 9.2 & N/A & N/A & $<\mathrm{MDL}$ & 9.2 & $<\mathrm{MDL}$ & 9.2 & 9.4 & 9.3 \\
\hline & \multirow{2}{*}{2} & 13-Oct-16 & 6.1 & 6.2 & 6.3 & 5.9 & 6.0 & 6.0 & 6.1 & 5.9 & 6.4 & 5.7 \\
\hline & & 13-Oct-16 & 6.0 & 6.2 & 5.9 & 6.1 & 5.9 & 6.0 & 6.3 & 6.0 & 6.2 & 6.2 \\
\hline & \multirow{2}{*}{3} & 14-Nov-16 & $<\mathrm{MDL}$ & 5.3 & 5.6 & 5.6 & 6.9 & 5.3 & 5.2 & 5.2 & 5.8 & 5.5 \\
\hline & & 14-Nov-16 & $<\mathrm{MDL}$ & 5.4 & 5.6 & 5.6 & 5.6 & 5.4 & 5.5 & 5.0 & 5.7 & 5.6 \\
\hline & \multirow{2}{*}{4} & 16-Nov-16 & $<\mathrm{MDL}$ & 5.3 & 5.7 & 5.7 & 5.5 & $<\mathrm{MDL}$ & 6.4 & 5.4 & $<\mathrm{MDL}$ & 6.3 \\
\hline & & 16-Nov-16 & $<\mathrm{MDL}$ & 5.4 & 5.6 & 5.2 & 5.7 & 5.9 & 5.6 & 5.4 & 6.0 & 6.0 \\
\hline \multirow{4}{*}{$\begin{array}{c}\text { Biopolymers } \\
(\mu \mathrm{g} / \mathrm{L})\end{array}$} & 1 & 14-Sep-16 & N/A & 324.1 & N/A & N/A & 210.7 & 175.0 & 170.7 & 159.5 & 369.3 & 348.1 \\
\hline & 2 & 13-Oct-16 & N/A & 177.3 & 178.1 & 181.7 & 517.0 & 204.9 & 173.7 & 162.0 & 176.4 & 166.3 \\
\hline & 3 & 14-Nov-16 & N/A & 190.9 & 189.1 & 203.4 & 210.8 & 194.4 & 201.4 & 202.3 & 207.7 & 198.7 \\
\hline & 4 & 16-Nov-16 & N/A & 190.9 & 168.6 & 167.9 & 170.1 & 169.0 & 157.3 & 164.4 & 160.9 & 157.7 \\
\hline \multirow{4}{*}{$\begin{array}{c}\text { Humic } \\
\text { substances } \\
(\mu \mathrm{g} / \mathrm{L})\end{array}$} & 1 & 14-Sep-16 & N/A & 1754.7 & N/A & N/A & 1617.2 & 1629.9 & 1590.4 & 1532.5 & 1516.7 & 1543.6 \\
\hline & 2 & 13-Oct-16 & N/A & 1762.4 & 1414.1 & 1609.5 & 1589.5 & 1245.5 & 1360.4 & 1467.7 & 1581.1 & 1503.8 \\
\hline & 3 & 14-Nov-16 & N/A & 1514.3 & 1496.2 & 1499.8 & 1321.2 & 1356.5 & 1363.3 & 1554.5 & 1421.5 & 1395.0 \\
\hline & 4 & 16-Nov-16 & N/A & 1514.3 & 1285.7 & 1323.1 & 1847.5 & 1191.9 & 1183.9 & 1394.0 & 1291.4 & 1732.3 \\
\hline
\end{tabular}


Table 7-6: Raw Data (Cont.)

\begin{tabular}{|c|c|c|c|c|c|c|c|c|c|c|c|c|}
\hline Analyte & Condition & Date & Raw & Settled & $\mathrm{O} 3$ & AOP & CAF & BAF & BAF & $\begin{array}{c}\text { BAC } \\
\text { Control }\end{array}$ & BAC & BAC \\
\hline \multirow{4}{*}{$\begin{array}{c}\text { Building } \\
\text { blocks } \\
(\mu \mathrm{g} / \mathrm{L})\end{array}$} & 1 & 14-Sep-16 & N/A & 1056.5 & N/A & N/A & 1495.1 & 1380.8 & 1372.2 & 1407.6 & 1376.6 & 1390.4 \\
\hline & 2 & 13-Oct-16 & N/A & 1126.3 & 1451.3 & 1199.0 & 1054.6 & 1435.3 & 1315.4 & 1334.5 & 1073.7 & 1122.3 \\
\hline & 3 & 14-Nov-16 & N/A & 763.6 & 675.7 & 881.1 & 1010.9 & 919.6 & 900.3 & 761.7 & 811.2 & 786.5 \\
\hline & 4 & 16-Nov-16 & N/A & 763.6 & 966.5 & 950.6 & 461.7 & 952.4 & 933.5 & 838.1 & 878.8 & 417.7 \\
\hline \multirow{4}{*}{$\begin{array}{l}\text { LMW } \\
\text { Neutrals } \\
(\mu \mathrm{g} / \mathrm{L})\end{array}$} & 1 & 14-Sep-16 & N/A & 953.8 & N/A & N/A & 748.9 & 791.0 & 764.2 & 739.2 & 787.9 & 792.9 \\
\hline & 2 & 13-Oct-16 & N/A & 883.5 & 827.9 & 790.5 & 926.1 & 772.3 & 825.0 & 915.1 & 842.9 & 808.9 \\
\hline & 3 & 14-Nov-16 & N/A & 420.8 & 439.7 & 468.7 & 395.0 & 357.0 & 373.9 & 391.8 & 350.7 & 375.6 \\
\hline & 4 & 16-Nov-16 & N/A & 420.8 & 378.8 & 371.9 & 366.7 & 380.4 & 367.9 & 409.1 & 355.9 & 386.7 \\
\hline
\end{tabular}

